\title{
A Paradoxical Convergence: National Identity and Gender in The Topp Twins Exhibition and the New Zealand Rugby Museum
}

\author{
Chelsea Torrance
}

A thesis submitted to Victoria University of Wellington in fulfilment of the requirements for the degree of Master of Arts in Museum and Heritage Studies 


\begin{abstract}
In May 2017, there was a strange convergence inside Palmerston North's Te Manawa museum. As visitors arrived on the first floor, they were left with two options. Turn left for the New Zealand Rugby Museum, or turn right for an exhibition on Jools and Lynda Topp. Left for masculinist rugby history. Right for radical activist lesbians. While both exhibitions have very different subject matter, themes of gender and national identity are prevalent within them both. Using this convergence as an entry point, this thesis considers the ways national identity and gender are put on display within the permanent exhibition at the New Zealand Rugby Museum and The Topp Twins exhibition.
\end{abstract}

Using data from interviews with key people involved with the two exhibitions, documentary research, and analysis of the two exhibitions, this thesis asks how New Zealand national identity and gender are narrated and displayed within The Topp Twins and the New Zealand Rugby Museum, and considers what this means for museum practice. In so doing, the thesis begins with an overview of key literature looking at nation, discourse and gender in museum and heritage scholarship. It also considers literature of New Zealand identity formation and gender. The intellectual foundation of this thesis resides in the idea that gender, nation and museums are intimately bound.

In the second part of the thesis, an investigation into the historical and contemporary context of the two exhibitions is conducted. This section provides an overview of the content and design of the exhibits. In combining both the context and content of the exhibitions, the thesis is able to consider intentions as well as the outcomes of the two. The final part of the thesis considers the ways national identity and gender have been presented within The Topp Twins exhibition and the New Zealand Rugby Museum. This 
chapter shows that while gender is presented in very different ways, the museums have a very similar narrative about 'New Zealandness'. 


\section{Acknowledgements}

I would first like to thank my supervisors, Dr Lee Davidson and Professor Charlotte Macdonald. Working with you both has been a privilege and an absolute joy. Thank you for the intellectual provocations, the warmth, and most importantly, the laughs.

This thesis could not have happened without the openness and generosity of my research participants, Andy Lowe, Siân Torrington, Bettina Anderson, and Stephen Berg. Thank you all for your time and the work you do.

I owe a debt of gratitude to my friends, who I am sure are all entirely sick of hearing about the Topp Twins and rugby. In particular, I owe a special thank you to Portia Allen, Stevie Jepson, Kate Jordan, Ethan McKenzie, Georgina O’Reilly, and Charlotte Thompson-Darling for their patience as my personality was slowly taken over by my thesis.

Thank you to my grandparents Evan and Zilla Torrance, and Elaine Hunt. I absolutely could not have done this without your support.

Finally, I would like to thank my two favourite bogans who both sacrificed a great deal to get me here.

To Andrew Torrance, my stabilising force. I know you secretly wish I was an accountant, but you have done a stellar job at learning to hide it.

To SJ, my mad, brilliant, and unflinchingly proud mother. You were not able to get the education you deserved, but I hope, in some way, this helps. 


\section{Table of Contents}

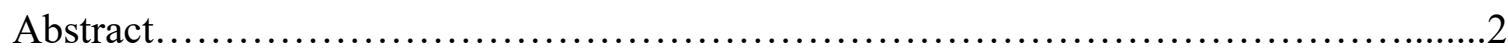

Acknowledgements..........................................................4

Table of Contents............................................................. 5

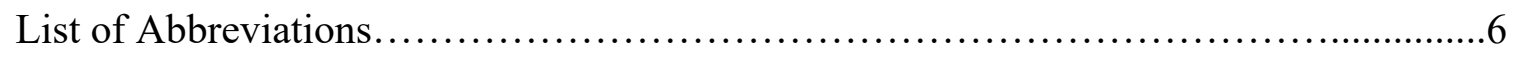

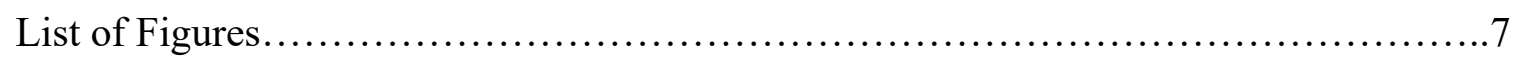

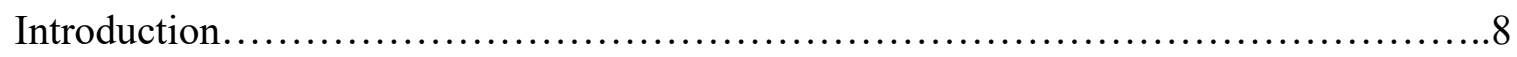

Chapter One: Literature Review and Research Design..............................14

Chapter Two: The Topp Twins exhibition.......................................43

Chapter Three: The New Zealand Rugby Museum..................................66

Chapter Four: Reading National Identity and Gender.............................91

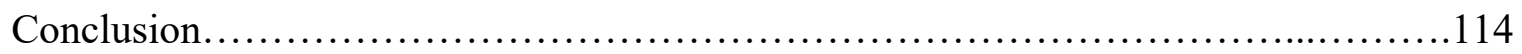

Bibliography.......................................................... 119 


\section{List of Abbreviations}

PNCC - Palmerston North City Council

NZRFU - New Zealand Rugby Football Union

NZR - New Zealand Rugby

AHD - Authorised Heritage Discourse 


\section{List of Figures}

Figure 1... Image from The Topp Twins, page 8

Figure 2... Image from The Topp Twins, page 45

Figure 3... Image from The Topp Twins, page 52

Figure 4... Image from The Topp Twins, page 54

Figure 5... Image from The Topp Twins, page 55

Figure 6... Image from The Topp Twins, page 56

Figure 7... Image from The Topp Twins, page 57

Figure $8 \ldots$ Image from The Topp Twins, page 58

Figure 9... Image from The Topp Twins, page 59

Figure 10...Image from The Topp Twins, page 60

Figure 11...Image from The Topp Twins, page 61

Figure 12... Image from the New Zealand Rugby Museum, page 73

Figure 13... Image from the New Zealand Rugby Museum, page 74

Figure 14... Image from the New Zealand Rugby Museum, page 77

Figure 15... Image from the New Zealand Rugby Museum, page 78

Figure 16... Image from the New Zealand Rugby Museum, page 80

Figure $17 \ldots$ Image from the New Zealand Rugby Museum, page 80

Figure 18... Image from the New Zealand Rugby Museum, page 81

Figure 19... Image from the New Zealand Rugby Museum, page 83

Figure $20 \ldots$ Image from the New Zealand Rugby Museum, page 84

Figure $21 \ldots$ Image from the New Zealand Rugby Museum, page 85

Figure $22 \ldots$ Image from the New Zealand Rugby Museum, page 86

Figure 23... Image from the New Zealand Rugby Museum, page 87

Figure 24...Image from The Topp Twins, page 100

Figure 25...Image from The Topp Twins, page 103

Figure 26...Image from The Topp Twins, page 105 


\section{Introduction}

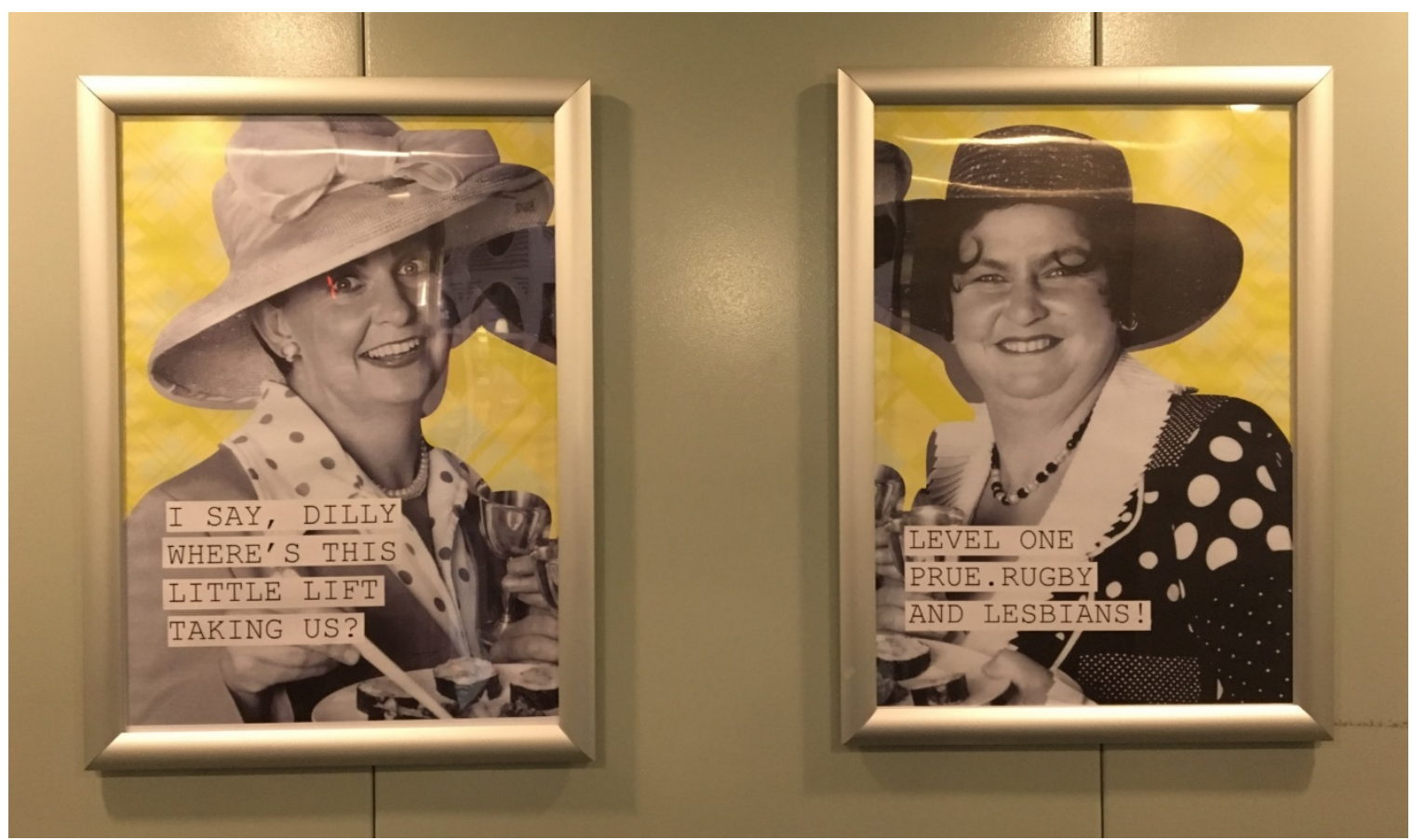

Figure 1. Signage in the elevator up to The Rugby Museum and The Topp Twins exhibition at Te Manawa. Photograph courtesy of Andy Lowe, 2017.

In May 2017, there was a strange convergence inside Palmerston North's Te Manawa museum. As visitors arrived on the first floor, they were left with two options. Turn left for the New Zealand Rugby Museum, or turn right for an exhibition on Jools and Lynda Topp. Left for masculinist rugby history. Right for radical activist lesbians. Call it ironic, hilarious, a delightful juxtaposition, paradoxical, or maybe even a tad strange. Whatever it is called, there is something undeniably intriguing about the proximity of the New Zealand Rugby Museum and The Topp Twins exhibition. This was not lost on staff and visitors at Te Manawa and the Rugby Museum. Looking at the two posters (figure one) displayed in the elevator up to the exhibitions, Te Manawa even went as far as to harness the intrigue of the odd pairing in their award-winning marketing campaign: "Level One... Rugby and Lesbians". ${ }^{1}$ As a Museum and Heritage Studies student, with an

${ }^{1}$ Andy Lowe, interview with author, 2018. 
undergraduate degree in History and Women's and Gender Studies, it proved too difficult to resist turning this odd moment in time, this convergence, into the subject of my thesis.

The New Zealand Rugby Museum has a long and proud history in Palmerston North, first opening its doors in 1977 . The museum provides a chronological history of rugby union in New Zealand from the nineteenth century colonial years, through to the 2011 Rugby World Cup. While the Māori All Blacks and the New Zealand women's team, the Black Ferns, are mentioned a few times, the museum's main focus is on the history of the All Blacks and their antecedents. The relationship between New Zealand identity and rugby is well documented, albeit contested. ${ }^{2}$ Aware of this relationship, the museum makes it clear their position on the matter, touting the tagline "the sport that shaped a nation."”

As the nation's sport, it is not uncommon to see the game and its players in the public eye. However, it seems that during the time period this thesis was written (2017-2018), New Zealand Rugby (NZR) has undergone some significant changes. While change is inevitable, rugby has faced some powerful challenges during this time period. In September 2017, NZR released their "Respect and Responsibility Review" in response to growing concerns around player conduct off the field. ${ }^{4}$ The review looked at issues such as player attitudes towards women, homophobia, and player mental health and wellbeing. In March 2018, it was announced that NZR would begin paying their women players in

\footnotetext{
2 See for example, Caroline Daley, 'The Invention of 1905' in Tackling Rugby Myths: Rugby and New Zealand Society, 1854-2004, ed. Greg Ryan (Dunedin: Otago University Press, 2005), 69-87.

3 'About Us,' New Zealand Rugby Museum, archived in January 2018 via Internet Archive, https://web.archive.org/web/20180121011738/http://rugbymuseum.co.nz/about-us/. ${ }^{4}$ Robyn Cockburn and Lucy Atkinson, 'Respect and Responsibility Review,' New Zealand Rugby, September 2017.
} 
the Black Ferns would receive a substantial pay increase. This increase, of course, is not anywhere near the level of what their All Black counterparts earn. In April 2018, not long after homophobic remarks from Australian rugby player Israel Folau and his Silver Ferns player wife, Maria Folau, went viral, New Zealand Rugby released a promotional video making the claim that "diversity is strength". ${ }^{5}$ In the video, Black Ferns and All Black players debuted limited edition jerseys that revealed rainbows when the fabric was stretched. The rainbow embedded jerseys gave a clear message that NZR is committed to becoming more inclusive and tolerant of 'diverse' peoples.

As the name of the exhibition suggests, The Topp Twins documents the lives and career of beloved New Zealand entertainers, Jools and Lynda Topp. The Twins wear many hats, they are country music singers, comedians, social justice activists, former stars of a comedy television show, current hosts of a food television show, openly queer public figures, and as of June 2018, Dame Companions of the New Zealand Order of Merit. The Twins are particularly noted for their character work with their (mostly) loving portrayal of certain (mostly) Pākehā stereotypes. ${ }^{6}$ Featured are West Auckland bogans, Brenda and Raelene; 'kiwi blokes' Ken Smythe (the townie) and Ken Moller (the farmer); Camp Mother and Camp Leader, who run a provincial camping ground; the 'old money' duo, Prue and Dilly; and the simple farm girls, the Gingham Sisters. Just as the subject matter in the Twins' work is distinctly New Zealand, The Topp Twins, too, is clearly a New Zealand production. This is particularly evident in the exhibition's tagline, "an exhibition

\footnotetext{
${ }^{5}$ Grant Chapman, 'NZ Rugby's "Diversity is Strength" campaign perfect answer to Folau fallout,' Newshub, 23 April 2018. https://www.newshub.co.nz/home/sport/2018/04/nzrugby-s-diversity-is-strength-campaign-perfect-answer-to-folau-fallout.html. 'I say 'mostly' here, as the Twins character repertoire includes a Jewish American woman. I will discuss further in Chapter Four about the potential that some characters are portrayed more lovingly than others.
} 
for New Zealand". ${ }^{7}$ The timing of The Topp Twins exhibition was deliberate, pre-empting celebrations of the Twins' sixtieth birthdays in 2018. The Topp Twins looked retrospectively at the Twins early lives, their upbringing, values, and all that they have achieved since they launched into the public eye in the 1980s. The exhibition is an acknowledgement of the Twins' position as iconic New Zealanders.

When I first embarked on this research, I thought The Topp Twins exhibition and the Rugby Museum would have little in common. I assumed that the focus of this thesis would be on the striking differences between the two - one was feminist, looking at the lives of two phenomenal women, and the other, presenting a history of (predominantly) men's heroic sporting achievements. The exhibitions are indeed very different, but at the heart of both, is a great love and appreciation for New Zealand. Thus, both The Topp Twins and the New Zealand Rugby Museum have become perfect subjects for discussing both gender and national identity. Throughout the course of this research, I interviewed key people involved with the two exhibitions. In a discussion about what made the Twins good subjects for an exhibition, Chief Executive of Te Manawa, Andy Lowe, explained that when it comes to the Twins, there is something, a particularly "fantastic kind of magic that happens with the paradox". ${ }^{8}$ The paradox surrounding the Twins relates to the fact that they are both queer, feminist activists and New Zealand icons. The culmination of those two subject positions are seemingly contradictory in nature, and yet, as Lowe notes, there is something particularly magical when those two worlds collide. The idea that there is something quite interesting about the Twins' paradoxical performance as

\footnotetext{
7 'The Topp Twins: An Exhibition for New Zealand,' Te Manawa, archived in August 2017 via Internet Archive, https://web.archive.org/web/20170810084035/https://www.temanawa.co.nz/topptwin s/.

${ }^{8}$ Andy Lowe, interview with author, 2018.
} 
both queer feminist activist and New Zealand icons has been explored elsewhere. ${ }^{9}$ If there is something particularly magical or productive with the Twins' paradox, what happens, then, when that paradox is extended to include the New Zealand Rugby Museum? Both The Topp Twins and the Rugby Museum together are contradictory in many ways, and yet, somehow, when it comes to New Zealand identity they converge. Both proclaim to be exhibitions of 'New Zealand', but can these be the same New Zealand?

In this thesis, I consider the paradoxical convergence of the New Zealand Rugby Museum and The Topp Twins exhibitions, questioning how and why the two exhibitions came to be, and the different ways national identity and gender have been negotiated and displayed. The thesis combines a close reading of the exhibition text, interviews with key museum staff, documentary analysis and contemporary media reports about the exhibitions to contextualise the exhibitions and the 'moment' they were produced within, the thesis explores the ways national identity and gender are displayed in the exhibitions, and discusses discuss what this 'moment' can teach us about museum practice in New Zealand.

In Chapter One, I introduce key literature, questions and methodologies that shape the research. The literature draws on a wide array of academic disciplines from gender studies, to museum and heritage studies, media studies and New Zealand history. In Chapter Two, I contextualise The Topp Twins exhibition, and discuss the key elements of the two exhibitions. This chapter combines interview data and textual analysis of the exhibition. In Chapter Three, I similarly contextualise the permanent exhibition at the

\footnotetext{
${ }^{9}$ See for example: Anita Brady, 'Camp Mothers of the Nation? Reading Untouchable Girls,' Women's Studies Journal 24, no. 1 (2010): 3-13; Lynda Johnston, 'The Topp Twins: Untouchable Girls: The Movie,' Emotion, Space and Society 2 (2009): 70-72.
} 
New Zealand Rugby Museum. In Chapter Four I review the content of the two exhibitions, and discuss the ways national identity and gender are displayed, reinforced and subverted. 


\section{Chapter One: Literature Review and Research Design}

In his chapter, 'National Museums and the National Imagination,' Simon Knell describes the national museum as a stage that nation is 'acted out' upon. ${ }^{1}$ Knell argues that "we might imagine national museums as providing the scenography and stage for the performance of myths of nationhood". ${ }^{2}$ While Knell's analysis does not extend beyond the walls of the national museum, this metaphor could be extended further to consider the performance of nation in the museum more generally. In her introductory chapter to the collection, Representing the Nation: A Reader. Histories, Heritage and Museums, Jessica Evans notes that "ideas of nation are created and embedded in... exhibitionary forms". ${ }^{3}$ Both Evans and Knell draw on Benedict Anderson's theory of an 'imagined' nation. ${ }^{4}$ Evans notes that museums and heritage are spaces where cultural and symbolic practices that solidify the 'imagined' bonds of nation are put on display. ${ }^{5}$ Here, it is clear that the nation is not only displayed within the museum, it is also constructed, embedded and performed.

In 2002, historian Peter Gibbons challenged his colleagues to move beyond national histories preoccupied with New Zealand's search for national definition. ${ }^{6}$ Gibbons explains that some New Zealand historians, particularly those concerned with national

\footnotetext{
${ }^{1}$ Simon Knell, 'National Museums and the National Imagination,' in National Museums: New Studies from Around the World, ed. Simon Knell, Peter Aronsson, and Arne Bugge Amundsen (London and New York: Routledge, 2010), 1-2.

2 Knell, 'National Museums and the National Imagination,' 2.

3 Jessica Evans, 'Introduction: Nation and Representation,' in Representing the Nation: A Reader. Histories, Heritage and Museums, ed. David Boswell and Jessica Evans (London and New York: Routledge and The Open University, 1999), 2.

${ }^{4}$ Evans, 'Introduction: Nation and Representation,' 1-2; Knell, 'National Museums and the National Imagination,' 1-3;

${ }^{5}$ Evans, 'Introduction: Nation and Representation,' 2-7.

${ }^{6}$ Peter Gibbons, 'Cultural Colonization and National Identity,' New Zealand Journal of History 36, no. 1 (2002): 5-17.
} 
history, treat nationalism, national identity and nationhood as naturally occurring phenomena. ${ }^{7}$ Histories focussing on New Zealand identity formation have often, Gibbons notes, ignored the ways national identity is an "ideological construction". ${ }^{8}$ In ignoring the constructed nature of New Zealand identity, these histories, Gibbons argues have become part of the colonising process, "not 'representations' of the past but practices with real and continuing consequences". ${ }^{9}$ Caroline Daley notes, one of the enduring consequences of the construction of a national mythology, is that it privileges men and their achievements. ${ }^{10}$ The nation, it seems, is embedded with ideas about gender, and nation is embedded within the museum. What happens, then, when New Zealand identity and the mythology surrounding it is put on display in the museum? If the museum, as Knell notes, can become a stage where nation is performed, then perhaps this one on of the enduring consequences Gibbons warned about?

The main aim of this research is to consider the convergence of national identity and gender in The Topp Twins exhibition and the New Zealand Rugby Museum. This chapter considers the intellectual entanglements of nation, gender and the museum, and lays a theoretical foundation that will make the study of The Topp Twins and the Rugby Museum possible. One of the great benefits of museum and heritage studies as a field of study is that it is by nature, interdisciplinary. As such, the foundation that this thesis is built upon draws on scholarship from a variety of different disciplines. In many ways it seems fitting that an investigation into the convergence of The Topp Twins exhibition and the New Zealand Rugby Museum requires the consultation of a convergence of cross-

\footnotetext{
${ }^{7}$ Gibbons, 'Cultural Colonization and National Identity,' 6-7.

${ }^{8}$ Gibbons, 'Cultural Colonization and National Identity,' 14.

${ }^{9}$ Ibid.

${ }^{10}$ Caroline Daley, 'The Invention of 1905' in Tackling Rugby Myths: Rugby and New Zealand Society, 1854-2004, ed. Greg Ryan (Dunedin: Otago University Press, 2005), 87.
} 
disciplinary scholarship. The literature in the chapter is split into two sections, one looks at museum and heritage studies literature, and the other looks at literature on New Zealand identity. The chapter will conclude with a discussion of research design and methodology.

Underwriting much of the literature surrounding gender and museums, is the notion that museums and heritage spaces are part of discourse, influenced by discourse, and authors of discourse. Laurajane Smith has gone as far as to argue that heritage does not exist, but rather, that it is a discursive construction. ${ }^{11}$ One of the most popular, and frequently cited frameworks for understanding dominant discourse in heritage comes from Smith's 2006, Uses of Heritage and her subsequent body of work. ${ }^{12}$ Smith argues that there is an “assumption that 'heritage' can be unproblematically identified as 'old', grand, monumental and aesthetically pleasing sites, buildings, places and artefacts". ${ }^{13}$ This assumption is shaped by a "hegemonic discourse" that Smith terms the Authorised Heritage Discourse, commonly known as the AHD. ${ }^{14}$ The AHD influences the way that people engage with heritage, privileging the “"old', grand, monumental and aesthetically pleasing" aspects of heritage. ${ }^{15}$ This is not to say that those aspects should not be considered heritage, or that the AHD is the only discourse about heritage, but rather, that it ensures "Western elite cultural values [are considered] universally applicable" at the

\footnotetext{
${ }^{11}$ Laurajane Smith, Uses of Heritage (London \& New York: Routledge, 2006), 11.

${ }^{12}$ Smith, Uses of Heritage.

${ }^{13}$ Smith, Uses of Heritage, 11.

14 Ibid.

15 Ibid.
} 
expense of "alternative and subaltern" forms of heritage. ${ }^{16}$ Smith notes that while the reach of the AHD is substantial, it can often be difficult to pinpoint the work the AHD does "as a social and cultural practice". ${ }^{17}$ This is in part due to the way the AHD is so naturally considered a universal discourse. The universal nature of heritage "actively obscures the power relations that give rise to it". ${ }^{18}$ The AHD in this way is normative and unquestioned, making it particularly difficult to grasp at and call into critique. However, this does not mean, Smith argues, that scholars should not attempt to grapple with it. ${ }^{19}$

Although the AHD signals dominant heritage, it has also become something of an analytical framework that has been adopted, cited, critiqued and built upon by many scholars. While this AHD has proven useful in articulating and making sense of some of the power structures that regulate and influence heritage, some believe that using the AHD as a lens of analysis has meant that dominant heritage discourse has been the subject of excessive focus. ${ }^{20}$ Zonhgjie Wu and Song Hou's overview chapter on heritage and discourse in The Palgrave Handbook of Contemporary Heritage Research is a useful entry point into heritage discourse beyond the AHD. ${ }^{21}$ Throughout their chapter, Wu and Hou make a case for discourse analysis within heritage scholarship, arguing that the discursive elements of heritage are integral to understanding the ways heritage shapes cultural knowledge in the present. ${ }^{22}$ Discourse analysis can, the pair argue, "reveal the

\footnotetext{
${ }^{16}$ Smith, Uses of Heritage, 11.

17 Smith, Uses of Heritage, 11, 16-17.

${ }^{18}$ Smith, Uses of Heritage, 11, 16-17.

${ }^{19}$ Smith, Uses of Heritage, 16.

${ }^{20}$ See for example: Zongjie Wu and Song Hou, 'Heritage and Discourse,' in The Palgrave Handbook of Contemporary Heritage Research, ed. Emma Waterton and Steve Watson (Hampshire \& New York: Palgrave Macmillan, 2015), 37-51.

${ }^{21} \mathrm{Wu}$ and Hou, 'Heritage and Discourse'.

${ }^{22} \mathrm{Wu}$ and Hou, 'Heritage and Discourse,' 37.
} 
power and ideological work embedded" within heritage. ${ }^{23}$ By revealing the discursive elements that underwrite heritage, it is possible to locate ways to problematise and in turn, disrupt heritage that privileges some over others. Put another way, by naming the dominant discourses that influence what counts as heritage, it is possible to call them into question, and advocate for different, and more diverse approaches to heritage production.

$\mathrm{Wu}$ and $\mathrm{Hou}$ argue that while heritage discourse analysis is valuable and necessary, there is a problem with the way heritage scholars have grappled with discourse in their work. ${ }^{24}$ In response to their critique that the AHD is too western, Wu and Hou advocate for a "newly emerging globalized heritage discourse" that seeks to decenter the Western perspective. ${ }^{25} \mathrm{Wu}$ and Hou note that while discursive frameworks can be useful, scholars often apply them without sufficient consideration of the unique local identities and settings they are researching. ${ }^{26}$ That is, in using frameworks such as the AHD to account for discourse and power within heritage, scholars often employ Western, globalised assumptions about spaces and places that may not so comfortably fit within a global discourse. ${ }^{27} \mathrm{Wu}$ and Hou outline a variety of ways scholars can engage with heritage discourse analysis without obscuring local identities and circumstances - this includes ensuring that indigenous and local voices are able to speak for themselves, that multiple ways of understanding the past are considered, and by shifting focus from authoritative global heritage to the ways people negotiate heritage in local settings. ${ }^{28}$

\footnotetext{
${ }^{23} \mathrm{Wu}$ and Hou, 'Heritage and Discourse,' 42.

${ }^{24} \mathrm{Wu}$ and Hou, 'Heritage and Discourse,' 46.

25 Ibid.

${ }^{26}$ Ibid.

27 lbid.

${ }^{28} \mathrm{Wu}$ and Hou, 'Heritage and Discourse,' 47-48.
} 
$\mathrm{Wu}$ and Hou's call to look beyond the globalising nature of the analytical frameworks of the AHD and others is an important step in further unsettling the power structures that regulate heritage. It does not mean, however, that attempting to identify an authorised heritage discourse is not a fruitful means of doing heritage discourse analysis. Smith herself notes at the very beginning of Uses of Heritage that there are issues with using the AHD to generalise heritage discourse. ${ }^{29}$ Acknowledging how this may prove problematic, Smith states her

task is to identify the general characteristics of the dominant discourse in heritage, and the way it both reflects and constitutes a range of social practices - not least the way it organizes social relations and identities around nation, class, culture and ethnicity. ${ }^{30}$

While it is important to consider critiques of the AHD, the analytical framework that Smith provides remains a crucial element of heritage discourse analysis. Although it may be easy to linger too long on the subject of dominant discourse, the effect it has on heritage cannot be ignored. "The way that people talk about, discuss and understand things such as "heritage'”, Smith concludes, "have a material consequence that matters". ${ }^{31}$

Prominent cultural theorist Stuart Halls keynote addresses some of the consequences of heritage discourse in a conference paper, 'Whose Heritage? Un-settling 'the Heritage', reimagining the post-nation'. In his paper, which was subsequently published in an edited collection, The Politics of Heritage: The Legacies of Race, Hall asks: what purpose, and

\footnotetext{
${ }^{29}$ Smith, Uses of Heritage, 16.

${ }^{30} \mathrm{lbid}$.

${ }^{31}$ Smith, Uses of Heritage, 14.
} 
for whom, does heritage serve $?^{32}$ Hall argues that heritage is inextricably bound up with national narratives, and notions of who does, and does not, "belong". ${ }^{33}$ By tracing who, and what heritage is for, Hall concludes that heritage is an exercise of power, reflecting the "authority of those who colonised the past" ${ }^{34}$ Heritage, therefore is underpinned by colonial discourse and history. The discursive elements of heritage, in Hall's eyes, ensure that those, in this case, people of colour, who pose a 'challenge' to cohesive or 'comfortable' national narratives do not often see themselves reflected within heritage. ${ }^{35}$ Although Hall's words are a reflection of the time (1999) and place (Britain) in which they were made, the idea that heritage, discourse and nation are intimately bound is a prominent theme throughout museum and heritage literature. According to Smith, in privileging the "materiality and innate value of heritage", the AHD reinforces the "comfortable and the 'good" elements of national narratives of heritage. ${ }^{36}$ One of the "comfortable" elements of the AHD, Smith contends, is the unquestioned nature of gender. 37 "Patriarchal heritage", Smith contends, is placed at the centre of authorised discourse. ${ }^{38}$ The AHD draws on and further perpetuates the idea that patriarchal heritage is a "consensual view" of nation and identity. ${ }^{39}$ In short, dominant discourses of heritage are often also reflections of normative masculinity.

\footnotetext{
32 Stuart Hall, 'Whose Heritage? Un-Settling "the Heritage", Re-Imagining the PostNation,' in The Politics of Heritage: The Legacies of Race, ed. Jo Littler and Roshi Naidoo (London \& New York: Routledge, 2005), 21-31.

${ }^{33}$ Hall, 'Whose Heritage?,' 22.

${ }^{34}$ Hall, 'Whose Heritage?,' 24.

${ }^{35}$ Hall, 'Whose Heritage?,' 22.

${ }^{36}$ Laurajane Smith, 'The "Doing" of Heritage: Heritage as Performance,' in Performing Heritage: Research, Practice and Innovation in Museum Theatre and Live Interpretation, ed. Anthony Jackson and Jenny Kidd (Manchester: Manchester University Press, 2012), 69-81.

${ }^{37}$ Smith, 'Heritage, Gender and Identity,' 160.

${ }^{38}$ Smith, 'Heritage, Gender and Identity,' 162.

39 Ibid.
} 
Both Smith and Hall show that when it comes to heritage, large forces are at play. Heritage is neither neutral or without power - it is a product of, and an expression of, power relations. With issues like colonialism and patriarchy feeding into the ways the AHD operates, it becomes clear that in order for heritage to change, so too do these wider power structures. This is no easy task. How then, can researchers discuss the AHD without it being a futile exercise? Smith argues that one of the ways this can be done, is by looking at heritage performance. ${ }^{40}$ In a chapter 'The 'Doing' of Heritage: Heritage as Performance', Smith challenges the idea that material and physical heritage are 'authentic' heritage. Rather, Smith notes that physical and material heritage are the "tools" used to remember the past and validate cultural and social experience. ${ }^{41}$ Heritage instead lies in visitation, curation, and the management of heritage - these are, according to Smith, performative acts of meaning making. ${ }^{42}$ Smith shows through her own visitor research that by focussing on heritage performance, it is possible to not only see how the AHD operates, but also how visitors, curators and heritage managers negotiate, challenge and mould the AHD to fit their own ideas and practices. ${ }^{43}$

In the editorial introduction to a special issue of the Journal of Australian Studies on feminism and the museum, Alison Bartlett and Margaret Henderson argue that museum studies literature severely lacks gender analysis. ${ }^{44}$ This is an idea that has been echoed

\footnotetext{
${ }^{40}$ Smith, 'The "Doing" of Heritage,' 80.

$41 \mathrm{lbid}$.

${ }^{42}$ Smith, 'The "Doing" of Heritage,' 70.

${ }^{43}$ Smith, 'The "Doing" of Heritage,' 76-80.

${ }^{44}$ Alison Bartlett and Margaret Henderson, 'Feminism and the Museum in Australia: An Introduction,' Journal of Australian Studies 40, no. 2 (2016): 132-33.
} 
elsewhere amongst scholars interested in museums, and in heritage. ${ }^{45}$ When the "new museology' emerged out of an edited collection of the same name in 1989, museum scholars began to shift their focus from the methods of the museum to its purpose. ${ }^{46}$ This shift has had a profound effect on museum scholarship. In recent years, we have seen a wealth of literature focussing on a variety of social justice and inclusion issues emerge: from discussions of accessibility for people with disabilities, to indigenous museology, environmentalism, and considerations of emotionality and affect. Museum studies literature has become "more reflective and politicised" ${ }^{47}$ Bartlett and Henderson argue that the similarly politicised nature of feminism and feminist scholarship means gender should be a natural fit within the scope of the new museology.$^{48}$ However, they argue that the continual lack of gender analysis in museum and heritage studies literature, continues to render the museum "a genderless domain". 49

While gender may not have had the seismic effect, it has had in other disciplines, there is still much that can be learned from those who have made gender, heritage and the museum the subject of their analyses. In conjunction with scholarship from other disciplines, I will discuss the ways gender has been, and can be, applied to the museum. I

\footnotetext{
${ }^{45}$ See for example, Laurajane Smith, 'Heritage, Gender and Identity,' in The Ashgate Research Companion to Heritage and Identity, ed. Brian Graham and Peter Howard (Hampshire: Ashgate, 2008), 165; Anna Reading, 'Making Feminist Heritage Work: Gender and Heritage,' in The Palgrave Handbook of Contemporary Heritage Research, ed. Emma Waterton and Steve Watson (Hampshire \& New York: Palgrave Macmillan, 2015), 398; Amy K. Levin, 'Introduction,' in Gender, Sexuality and Museums: A Routledge Reader (London \& New York: Routledge, 2010), 1.

${ }^{46}$ Bartlett and Henderson, 'Feminism and the Museum in Australia,' 131; Peter Vergo, ed., The New Museology (London: Reaktion Books, 1989), 4-5.

${ }^{47}$ Bartlett and Henderson, 'Feminism and the Museum in Australia,' 132.

48 Ibid.

${ }^{49}$ Alison Bartlett and Margaret Henderson, 'Feminism and the Museum in Australia: An Introduction,' Journal of Australian Studies 40, no. 2 (2016): 133.
} 
will begin by looking at how museum and heritage studies literature has addressed gendered representations in museums and heritage space and will conclude by examining the ways interdisciplinary research can show a path beyond simply looking at representation.

The origins of the museum are patriarchal. ${ }^{50}$ Although this has not been without protest, or women's involvement, for much of museum history, museums have concerned themselves with the interests of wealthy Western men. ${ }^{51}$ From the objects museums have collected, to the people they employ and the audience they have attracted, women have been paid far less attention than men. ${ }^{52}$ Women, along with other marginalised peoples, have found it particularly difficult to penetrate the walls of the museum. ${ }^{53}$

In her pioneering study on women in British history museums, Gaby Porter turned a poststructural feminist eye to the ways museums handle issues of gender. ${ }^{54}$ From collection strategies, to display, and employment relations, Porter's research was one of the first to identify the museum's ‘woman problem'. Initially situated within her PhD thesis in 1994, 'Studies in Gender and Representation in British History Museums', Porter later refined her ideas in a chapter published in Sharon Macdonald and Gordon Fyfe's Theorizing Museums in $1996 .{ }^{55}$ More than twenty years on, Porter's chapter, 'Seeing Through

\footnotetext{
${ }^{50}$ Levin, 'Introduction,' 1-3.

51 lbid.

52 lbid.

$53 \mathrm{lbid}$.

54 Gaby Porter, 'Seeing through Solidity: A Feminist Perspective on Museums,' in Theorizing Museums, ed. Sharon Macdonald and Gordon Fyfe (Woodbridge, UK: Blackwell Publishers, 1996), 105-26.

55 Gaby Porter, 'Studies in Gender and Representation in British History Museums' (PhD, University of Leicester, 1994); Porter, 'Seeing through Solidity: A Feminist Perspective on Museums.'
} 
Solidity', remains one of the most thorough analyses of women in the museum. Porter argues that within the museums she studied, women, if they were included at all, were often given a subordinate role as subjects of display in exhibitions. ${ }^{56}$ Not only were women subordinated within history displays, they were also presented in a one dimensional and stereotypical manner. ${ }^{57}$ In contrast, men were often displayed in more thoughtful and nuanced ways. The variety of men's lived experiences was paid more attention. ${ }^{58}$ Although museum and heritage practice has moved on since Porter began her research in the late 1980s, more recent literature shows that gender disparities in exhibitions remain a pervasive issue. Rebecca Machin notes that this disparity is not simply isolated to human history. ${ }^{59}$ Looking at representations of gender in natural history displays, Machin shows that female animals are often subordinated in comparison to their male counterparts. ${ }^{60}$ Machin argues that male animals are privileged by being included in far greater numbers, being positioned in dominant positions, and via the language used in interpretation texts. ${ }^{61}$

Laurajane Smith’s 2008 chapter ‘Heritage, Gender and Identity’ and Anna Reading’s 2015 chapter 'Making Feminist Heritage Work' mirror some of the key assertions made by Porter and Machin. ${ }^{62}$ Looking beyond the issue of stereotypical portrayals of women,

\footnotetext{
56 Porter, 'Seeing through Solidity,' 112.

57 lbid.

58 Ibid.

${ }^{59}$ Rebecca Machin, 'Gender Representation in the Natural History Galleries at the Manchester Museum,' in Gender, Sexuality and Museums: A Routledge Reader, ed. Amy K. Levin (London \& New York: Routledge, 2010), 188.

${ }^{60}$ Machin, 'Gender Representation in the Natural History Galleries at the Manchester Museum,' 188-95.

${ }^{61}$ Machin, 'Gender Representation in the Natural History Galleries at the Manchester Museum,' 196.

62 Smith, 'Heritage, Gender and Identity'; Reading, 'Making Feminist Heritage Work: Gender and Heritage.'
} 
both Smith and Reading illustrate that gender disparities go far deeper than museum display. Smith argues that exhibitions that consider women and gender in more nuanced and thoughtful ways frequently take the form of a 'special' or temporary exhibition. Smith argues that this relegation to impermanent exhibition spaces, residing alongside, but not within, larger national narratives, further perpetuates the dominance of masculine heritage. ${ }^{63}$ Smith and Reading note that in heritage literature, like many other disciplines, gender often becomes shorthand for women. ${ }^{64}$ Unlike other disciplines, however, Smith contends that heritage literature remains firmly in the remedial "add women and stir" phase of addressing gender inequities. ${ }^{65}$ Reading claims that further work needs to be done to consider both masculinity and femininity within heritage scholarship. ${ }^{66}$ Focussing on the constructions of masculinity and femininity ensures that gender is placed in both the domain of men and women. ${ }^{67}$ Although both chapters focus predominantly on heritage, Smith and Reading's arguments could easily encompass both heritage and the museum.

Few scholars have written about masculinity, heritage and gender. Those who have published on the subject, however, provide compelling evidence for the continuation of such a line of inquiry. Laurajane Smith's article 'A Pilgrimage of Masculinity' is particularly illuminating. ${ }^{68}$ Smith uses the Australian Stockman's Hall of Fame in the Queensland outback as a case study. The Hall's museum covers a wide range of topics

\footnotetext{
${ }^{63}$ Smith, 'Heritage, Gender and Identity,' 166, 168.

${ }^{64}$ Reading, 'Making Feminist Heritage Work,' 400-01; Smith, 'Heritage, Gender and Identity,' 159.

${ }^{65}$ Smith, 'Heritage, Gender and Identity,' 162-63.

${ }^{66}$ Reading, 'Making Feminist Heritage Work,' 401.

67 Ibid; Smith, 'Heritage, Gender and Identity,' 166, 168.

${ }^{68}$ Laurajane Smith, 'A Pilgrimage of Masculinity: The Stockman's Hall of Fame and Outback Heritage Centre,' Australian Historical Studies 43, no. 3 (2012): 472-82.
} 
relating to life in the Australian bush. Smith notes that in recent years, the Hall has undergone many revisions to ensure that women and Aboriginal and Torres Strait Island peoples have been included in the Hall's narrative. ${ }^{69}$ Smith illustrates, via visitor interviews, that while the Hall may have become more inclusive, visitors paid little notice. ${ }^{70}$ Smith argues visitors bring with them preconceived masculine discourses of the Australian bushman on their 'pilgrimage' to the Hall. ${ }^{71}$ Smith's article shows that while heritage sites and museums can, and should, problematise patriarchal narratives, wider issues of masculinity, nation and identity cannot be so simply "curated away". ${ }^{72}$

The problem of nation and identity are at the centre of both Cara Aitchison, and Tim Edensor and Uma Kothari's chapters on masculinity and heritage. ${ }^{73}$ Aitchison, and Edensor and Kothari use case studies of heritage in the town of Stirling, Scotland. Stirling was the site of the First War of Scottish Independence, which was popularised by the 1995 film Braveheart. Aitchison's chapter sought to build on Edensor and Kothari's early arguments, by incorporating the impact the film had on the tourism industry. Edensor and Kothari argue that heritage spaces in Stirling have appropriated masculine discourses of militarism to create a unique local identity. ${ }^{74}$ By drawing on the town's place in Scotland's struggle for independence, Edensor and Kothari argue that Stirling's constructed local identity privileges heterosexual, white, male experience. ${ }^{75}$ Aitchison

\footnotetext{
${ }^{69}$ Smith, 'A Pilgrimage of Masculinity,' 473.

70 Smith, 'A Pilgrimage of Masculinity,' 476-81.

${ }^{71}$ Smith, 'A Pilgrimage of Masculinity,' 482.

72 Ibid.

${ }^{73}$ Cara Aitchison, 'Heritage and Nationalism: Gender and the Performance of Power,' in Leisure/Tourism Geographies: Practices and Geographical Knowledge (Abingdon, UK: Taylor and Francis, 2000), 59-73; Tim Edensor and Uma Kothari, 'The Masculinisation of Stirling's Heritage,' in Tourism: A Gender Analysis (Chichester, UK: Wiley, 1994), 164-87.

${ }^{74}$ Edensor and Kothari, 'The Masculinisation of Stirling's Heritage,' 167.

${ }^{75}$ Edensor and Kothari, 'The Masculinisation of Stirling's Heritage,' 165.
} 
argues that the process of drawing on patriarchal discourses of the past to reinforce masculine power in the present moment is prevalent across the heritage industry. ${ }^{76}$ Edensor and Kothari ruminate on the effect masculine heritage has on visitor and tourist engagement, arguing that those who fall outside of the heterosexual, white, male experience may feel excluded from the local or national heritage. ${ }^{77}$ Although this argument is invariably true for some, Smith challenges the idea that people who fall outside of the limited scope of masculine heritage feel excluded from it. ${ }^{78}$ Smith's wider body of work focuses on the ways visitors negotiate, appropriate, and challenge different heritage discourses during their engagements with heritage sites and museums. ${ }^{79}$ Smith argues that a wider heritage discourse ensures that even those outside of the heterosexual, white, male experience relate to its heritage.

Considering the New Zealand Rugby Museum and The Topp Twins exhibition raises particularly interesting questions around both gender and sexuality. While discussions of gender often lend themselves to discussions of sexuality and vice versa, it is pertinent to consider the issue of sexuality in the museum context. There is a small, growing body of literature that looks at queer representation in museums. Anna Conlan's 'Representing Possibility: Mourning, Memorial and Queer Museology’ discusses the consequences of heteronormative museology. ${ }^{80}$ Conlan introduces the chapter by discussing a photograph that struck her during her undergraduate art history studies. The photograph was of Alice

\footnotetext{
${ }^{76}$ Aitchison, 'Heritage and Nationalism,' 71-72.

77 Edensor and Kothari, 'The Masculinisation of Stirling's Heritage,' 168.

${ }^{78}$ Smith, 'A Pilgrimage of Masculinity,' 482; Smith, 'Heritage, Gender and Identity,' 16869.

${ }^{79}$ See for example: Laurajane Smith, 'The "Doing" of Heritage.'

${ }^{80}$ Anna Conlan, 'Representing Possibility: Mourning, Memorial, and Queer Museology,' in Gender, Sexuality and Museums, ed. Amy K. Levin (London \& New York: Routledge, 2010), 253-63.
} 
B. Toklas standing in front of a Picasso portrait of her deceased partner, Gertrude Stein, at an exhibition in Paris. The portrait previously hung in the home the two shared, however, Toklas reluctantly parted ways with it after Stein died. Looking at letters sent by Toklas to close friends, Conlan notes that Toklas found it incredibly difficult to part with the painting, as it represented the life Stein and she shared together - a queer life. While discussing the photograph with her class, Conlan notes she was moved to tears in both "sadness and anger". ${ }^{81}$ Conlan uses Toklas' mourning at an exhibition, as well as her own mourning, as an entry point into a discussion of the erasure of queer lives in the museum setting. Drawing on the main question posed in Judith Butler's Bodies That Matter "who counts as human... what makes for a grievable life?", Conlan argues that the museum eradicates the possibility of Toklas' queer mourning because the lesbian context behind the painting had been obscured. ${ }^{82}$ The photograph of Toklas at the exhibition gave a small glimpse into the queer context of a portrait concealed by the museum's clinical and institutional setting. Conlan argues that as both a "product and producer of power", the museum "renders thinkable and legitimates the world it represents". Queer lives, Conlan, notes are "cast in the shadow of the museum's authority". ${ }^{83}$

Queer lives, in the context of Conlan's example, have been made unintelligible by the museum because they are un-named. If Toklas and Stein's queer lives cannot be seen, they are not 'bodies that matter' - their lives are neither grievable or fully human. While her claims relate to an exhibition in 1955 , in reciting her own mourning when looking at the image in the 2000s, Conlan shows that museums' denial of queer lives remains something to grieve. In Sex Museums: The Politics and Performance of Display, Jennifer

\footnotetext{
${ }^{81}$ Conlan, 'Representing Possibility,' 253-54.

82 Judith Butler, as cited in Conlan, 'Representing Possibility,' 257.

${ }^{83}$ Conlan, 'Representing Possibility,' 257.
} 
Tyburczy unpicks the ways museums shape sexual meaning. ${ }^{84}$ Although she argues that sexual meaning is created in all museums regardless of intent, for the most part Tyburczy's analysis focuses on museums of sex and exhibitions that deal explicitly with sex. Tyburczy contends that museum exhibitions often reinforce heteronormative gender and sexual relations. In response to the frequent display of heteronormativy, Tyburczy outlines a framework for what she describes as “queer curatorship". Tyburczy outlines "queer curatorship" as being

an experimental display tactic that stages alternative spatial configurations for two distinct purposes: (1) to expose how traditional museums socialize heteronormative relationships between objects and visitors and (2) to cope with ethically fraught objects of queer cultures. ${ }^{85}$

Tyburczy's concerns primarily reside in the spatial elements of museums, noting that "queer curatorship is simultaneously a mode for studying how museums place objects in normative sexual relationships through the curatorial citation and repetition of familiar arrangements, juxtapositions, and chronologies" and "a method for experimenting with object arrangements toward the cultivation of other sexual-social relationships." 86 Tyburczy applies this framework to exhibitions that display objects relating to sadomasochism, however, the concept of "queer curation" could be pushed further beyond exhibitions that deal explicitly with sex. Conlan and Tyburczy's work is particularly illuminating in considering both The Topp Twins and the New Zealand Rugby

\footnotetext{
84 Jennifer Tyburczy, Sex Museums: The Politics and Performance of Display (Chicago \& London: University of Chicago Press, 2016).

${ }^{85}$ Tyburczy, Sex Museums, 175.

${ }^{86}$ Tyburczy, Sex Museums, 198.
} 
Museum. While one space is filled with queer material, the other, does not discuss sexuality at all. As the literature on gender and museum has shown, patriarchal heritage is often unquestioned, and in turn displayed as unspoken 'norm'. Conlan and Tyburczy both show the that the sexuality is also often unquestioned in the museum, with heterosexuality being a similarly unspoken 'norm', and show this too has 'material' consequences.

Looking at literature on queer representation and curation and museums has proven particularly illuminating, particularly considering The Topp Twins exhibition. For the New Zealand Rugby Museum, looking at literature on sports museums is similarly illuminating. In a 2012 chapter, 'Sport in Museums and Museums of Sport,' Kevin Moore notes that while scholarship looking at sports museums, and sport in museums has grown in recent years, he argues that the literature remains sparse and limited ${ }^{87}$ Moore claims that sports museums exist in the margins of popular culture. While popular culture has been more readily accepted into the museum, Moore argues that because sports are often seen as not part of culture, and in many cases, the very antithesis of culture, they have not been so readily included in museums as other elements of pop culture. Moore's chapter provides a useful outline for the issues facing sports museums, and sport in museums.

A key concern for sports museum is scope, as many sports collections exist outside of the museum setting, for example, amateur collections displayed in collectors' homes. ${ }^{88}$ In the introductory chapter to his edited collection, Representing the Sporting Past in Museums and Halls of Fame, Murray G. Phillips lays out a framework for researching sports

\footnotetext{
${ }^{87}$ Kevin Moore, 'Sport in Museums and Museums of Sport: An Overview,' in Sport, History, and Heritage, ed. Jeffrey Hill, Kevin Moore and Jason Wood (Woodbridge, UK: Boydell Press, 2012), 93.

${ }^{88}$ Moore, 'Sport in Museums and Museums of Sport,' 96.
} 
museums that can be loosely divided into four categories, the academic, the vernacular, the corporate, and the community. ${ }^{89}$ Academic museums, are those that are publicly funded, bound by more strict academic conventions. The vernacular are places where sports collections are displayed outside of a museum setting, for example, in a café or shop. Corporate museums are those that are funded by private ventures, more often, by the sports bodies that govern the sport the museum displays. Finally, the community museum is an amateur venture, largely run through the support of volunteers. ${ }^{90}$ Moore, building on Phillips' work, notes that while these categories are useful, the lines between the four are indistinct, and many museums do not fit comfortably into a single category. ${ }^{91}$ Phillips argues that in comparison to the other categories, there is a lack of 'academic' sports museums. ${ }^{92}$ Wray Vamplew discusses this issue at length in an article on public sports history in sports museums. Vamplew despairs that due to the pressure corporate museums face from their sponsors, sports museums are unable to remain independent, and in turn historically accurate. ${ }^{93}$

Issues of accuracy are less important to Moore. Moore questions whether academic criticism of sports museums such as Vamplew's are fair. ${ }^{94}$ Academic criticism, Moore notes, "tend to focus on the issue that they reflect uncritical, celebratory history". ${ }^{95}$ While Moore notes that the criticism that sports museums, particularly corporate ones, have a

\footnotetext{
${ }^{89}$ Murray G. Phillips, 'Introduction: Historians in Sports Museums,' in Representing the Sporting Past in Museums and Halls of Fame, ed. Murray G. Phillips (London \& New York: Routledge, 2012), 1-28.

$90 \mathrm{lbid}$.

${ }^{91}$ Moore, 'Sports Museums and Museums of Sport,' 92.

92 Phillips, 'Introduction: Historians in Sports Museums,' 12.

${ }^{93}$ Wray Vamplew, 'Taking a Gamble or a Racing Certainty: Sports Museums and Public Sports History,' Journal of Sport History 31, 2 (2004): 187.

${ }^{94}$ Moore, 'Sports Museums and Museums of Sport,' 95.

$95 \mathrm{lbid}$.
} 
tendency towards nostalgia and celebration is valid, but at the same time, he questions the issue with nostalgic displays. ${ }^{96}$ Moore argues that nostalgia is a vital and enjoyable part of sports museums. He also notes that sports museums that are not publicly funded have "no responsibility to provide objective history for the public benefit". ${ }^{97}$ So, although it may be a bugbear for sports historians, Moore implores those researching sports museums to consider the purpose of sports museums, and most importantly their audience. Audiences, Moore argues provocatively, do not usually walk into a sports museum looking for accurate public history. ${ }^{98}$ Moore concludes by promoting the idea that sports museums should be encouraged to "harness the positive aspects of nostalgia." While Moore's study may be controversial, his arguments provide a great overview of some of the issues sports museums face. In particular, issues of accuracy, nostalgia, funding, ownership and audience.

Moving beyond the museum, sport, in particular, rugby has played a vital role in debates around and accounts of New Zealand national identity, and the 'cultural colonisation' of histories that deal with these narratives unproblematically. Written in 1986, Keith Sinclair's A Destiny Apart: New Zealand's Search for National Identity is a prime example of what Gibbons railed against. ${ }^{99}$ While there are many other examples, Sinclair's is particularly interesting in this context, due to his emphasis on the role of rugby and war in shaping New Zealand identity. In one particular chapter, Sinclair

\footnotetext{
96 Moore, 'Sports Museums and Museums of Sport,' 95.

${ }_{97}$ Moore, 'Sports Museums and Museums of Sport,' 96-97.

98 Ibid.

${ }^{99}$ Keith Sinclair, A Destiny Apart: New Zealand's Search for National Identity (Wellington: Allen \& Unwin, 1986).
} 
discusses the 1905 "Originals" New Zealand rugby overseas tour. ${ }^{100}$ While $1888-89$

'Natives' team had gone before them, the Originals were the first 'official' New Zealand rugby union team to tour overseas beyond Australia. The team won all games except one, which Sinclair dubs "the Gallipoli of New Zealand sport". ${ }^{101}$ Sinclair saw this highly successful team as a turning point for New Zealand identity, noting that "what had occurred is famous in the New Zealand secular religion of nationalism". ${ }^{102}$ The team was successful, Sinclair argues, due to the physical superiority of New Zealand men. ${ }^{103}$ For Sinclair, this successful tour was a testament to the New Zealand character, and one of the earliest spaces where a distinct national identity began to take shape. ${ }^{104}$ In 'The Invention of 1905', Caroline Daley argues that the significance of the 1905 tour was an invention of historians' own making. ${ }^{105}$ Daley argues that while 1905 may well be an interesting moment in New Zealand history, the physical prowess of the players, along with the extent to which the game was popular back home in New Zealand, has been greatly exaggerated. ${ }^{106}$ Daley concludes by noting that "too often sport is seen as a measure of the nation and growing nationalism, with rugby as the ultimate national game. Too often the All Blacks have to be the exemplars of masculinity". ${ }^{107}$

It is difficult to research New Zealand masculinity and the 'kiwi bloke' without encountering Jock Phillips' A Man's Country? ${ }^{108}$ Originally published in 1987, Phillips

\footnotetext{
100 Sinclair, A Destiny Apart, 141-156.

101 Sinclair, A Destiny Apart, 147.

102 Sinclair, A Destiny Apart, 149.

${ }^{103}$ Sinclair, A Destiny Apart, 150-152.

104 Sinclair, A Destiny Apart, 143.

${ }^{105}$ Caroline Daley, 'The Invention of 1905'.

${ }^{106}$ Daley, 'The Invention of 1905,' 69-71.

107 Daley, 'The Invention of 1905,' 87.

108 Jock Phillips, A Man's Country? The Image of the Pakeha Male: A History, $2^{\text {nd }}$ edition (Auckland: Penguin, 1997).
} 
argues that an early colonial gender imbalance meant Pākehā men looked "to other men for support and company", which he believes turned New Zealand into a “man's country". ${ }^{109}$ Phillips introduces the reader to the stereotypical men who have made New Zealand 'a man's country' over time: the pioneer, boozer, decent bloke, hard man, military man's man, and finally, the family man. ${ }^{110}$ In 1997 Phillips revised the text, adding in a further chapter on the seventh kiwi bloke: the bloke under siege. ${ }^{111}$ These stereotypes, Phillips argues, are detrimental to both women and men. ${ }^{112}$ For men, Phillips notes, the "male stereotype" impacts upon their behaviour, and limits the choices they are able to make in their lives. ${ }^{113}$

Robin Law, Hugh Campbell and John Dolan's edited collection Masculinities in Aotearoa/ New Zealand combines interdisciplinary research on the ways a variety of experiences and subjectivities influence masculinity in New Zealand. ${ }^{114}$ Law, Campbell and Dolan argue that masculinity studies in New Zealand ought to "go beyond blokes", and "think about the ways in which various masculinities are constructed, reinforced, represented and contested". ${ }^{115}$ Law, Campbell and Dolan's collection show that there are many different ways to achieve this, encompassing a wide array of disciplines and subjectivities. Recent interrogations of gender and masculinity have looked at issues such as class, disability, sexuality, race, and geography.

\footnotetext{
109 Phillips, A Man's Country?, 9.

110 Phillips, A Man's Country?.

111 Phillips, A Man's Country?, 262-289.

112 Phillips, A Man's Country?, ix.

113 Phillips, A Man's Country?, viii.

${ }^{114}$ Masculinities in Aotearoa/New Zealand, ed. Robin Law, Hugh Campbell and John Dolan (Palmerston North: Dunmore Press, 1999).

115 Robin Law, Hugh Campbell and John Dolan, ed., 'Preface,' in Masculinities in Aotearoa/ New Zealand (Palmerston North: Dunmore Press, 1999), 7.
} 
In her chapter 'Queer, Here: Sexuality and Space', in Cultural Studies in Aotearoa New Zealand, Lee Wallace argues that there is a "long national tradition of implying that there is a queer underside to everything and saying nothing more about it". ${ }^{116}$ An example of the New Zealand's 'queer underside' can be seen in Anita Brady's analysis of the Speight's beer 'Southern Man' advertisements. ${ }^{117}$ Brady argues Speight's seeks to link itself with "a legitimized performance of maleness", using tropes of pioneering Pākehā masculinity to do so. ${ }^{118}$ Looking at the gendered performances in the Speight's advertisements Brady contends that New Zealand national identity is not produced according to a male/female binary, but rather as gendered/transgendered. ${ }^{119}$ Brady notes that while there is a distinct masculine element to New Zealand identity, there is very little evidence that there is a female equivalent. ${ }^{120}$ In one particular advertisement, "Perfect Girl", one of the protagonists stops dating a seemingly 'perfect girl' because she does not drink his beer of choice. Brady argues that if the 'perfect girl' drinks Speight's, and the correct performance of masculinity hinges on drinking Speight's, then the 'perfect girl' is not female, but rather "misperformed masculinity". ${ }^{121}$ According to the pioneering Pākehā masculinity that the advertisements draw upon, the 'perfect girl' is "not quite man enough for a real Southern Man". ${ }^{22}$ This is not to say that the Southern Man is

\footnotetext{
116 Lee Wallace, 'Queer, Here: Sexuality and Space,' in Cultural Studies in Aotearoa/ New Zealand (Melbourne: Oxford University Press, 2004), 67-68.

117 Anita Brady, 'The Transgendered Kiwi: Homosocial Desire and 'New Zealand Identity,' Sexualities 15, no. 3/4 (2012): 355-372.

118 Brady, 'The Transgendered Kiwi,' 356.

${ }^{119}$ Brady, 'The Transgendered Kiwi,' 357-358.

${ }^{120}$ Brady, 'The Transgendered Kiwi,' 356-357.

121 Brady, 'The Transgendered Kiwi,' 365-366.

122 Brady, 'The Transgendered Kiwi,' 364.
} 
homosexual, but rather, Brady's article points to the idea that legitimized performances of masculinity and New Zealand national identity rely on a 'queer underside'. ${ }^{123}$

The aforementioned article was not Brady's first foray into the 'queer underside' of New Zealand identity. In 2010, Brady published an article in response to the documentary The Topp Twins: Untouchable Girls and its subsequent success. ${ }^{124}$ Here Brady notes that the film "almost universally draws attention to the disjunction between [the Twins'] lesbianism, and their relationship with 'heartland' New Zealand", and argues that there may be something "a little queer" about the fact that the Twins are "representative of the very New Zealand their 'yodelling lesbian twin' status seems to so intuitively contradict". ${ }^{125}$ Brady dubs this as a "lesbian/icon paradox". ${ }^{126}$ Again, using beer advertising as an anchor to her analysis, Brady argues that the Twins' characters Ken and Ken are so wholly accepted as "true blue boys" because they re-enact a form of authentic New Zealand masculinity that beer advertising often cites. ${ }^{127}$ Brady, along with other scholars cited in this literature review, draws heavily on the work of Judith Butler. Of particular interest here, is Butler's theories around gender performativity. While even Butler herself finds it difficult to pinpoint a precise definition of gender performativity, ${ }^{128}$ put simply, gender performativity is the idea that gender is not innate, but rather

\footnotetext{
${ }^{123}$ Brady, 'The Transgendered Kiwi,' 368-369.

${ }^{124}$ Brady, 'Camp Mothers of the Nation? Reading Untouchable Girls,' Women's Studies Journal 24, no. 1 (2010): 3-13.

125 Brady, 'Camp Mothers of the Nation?,' 3-4.

${ }^{126}$ Brady, 'Camp Mothers of the Nation?,' 4.

${ }^{127}$ Brady, 'Camp Mothers of the Nation?,' 7.

128 Judith Butler, 'Preface (1999),' Gender Trouble: Feminism and the Subversion of Identity, $2^{\text {nd }}$ edition (London \& New York: Routledge, 1999), xiv.
} 
something that is performed. ${ }^{129}$ Throughout her extensive body of work, Butler has looked at the ways different people with different bodies can perform gender. Through a series of repetitions, certain performances of gender become more 'acceptable' than others. ${ }^{130}$ Butler often refers to this as coherence or legibility. By citing authorised performances of gender, those with coherent gender performances help to further perpetuate its dominance. ${ }^{131}$ Those who cannot be read as performing coherent gender are deemed as incoherent, illegible, and in some cases, 'trouble'. ${ }^{132}$ Drawing on Butler, Brady questions whether the Twins" depiction of Ken and Ken is "truly troubling" of kiwi bloke masculinity or simply "rearticulating" the power it holds. ${ }^{133}$ Because the Twins never let their audience forget that they are lesbians while they are performing 'authentic' kiwi bloke masculinity, Brady argues that they could be read as subverting the men they so lovingly portray. ${ }^{134}$ Brady's application of gender theory to the Topp Twins' career is particularly salient here, and provides a helpful framework for considering the ways gender and national identity can be negotiated within the context of The Topp Twins.

In the opening chapter of his collection of essays, Hyperreality and Global Culture, Nicholas Perry provokes readers to consider the concept of 'camp', perhaps most notably defined by Susan Sontag in 1964, from the perspective of Down Under. ${ }^{135}$ Weaving together politics, film and literary criticism, Perry outlines a framework for “Antipodean

\footnotetext{
${ }^{129}$ As a Butler novice, I find her preface in the revised edition of Gender Trouble, along with her introductory remarks in Bodies that Matter to be most fruitful here; Judith Butler, Bodies That Matter, (London \& New York: Routledge, 1993), 1-3.

130 Judith Butler, Undoing Gender, (London \& New York: Routledge, 2004), 13-14.

${ }^{131}$ Butler, Gender Trouble, 174; Butler, Bodies That Madder, 1-3.

132 Butler, Gender Trouble, 137-138.

${ }^{133}$ Brady, 'Camp Mothers of the Nation?,' 10.

${ }^{134}$ Brady, 'Camp Mothers of the Nation?,' 10-12.

135 Nicholas Perry, Hyperreality and Global Culture (London \& New York: Routledge, 1998).
} 
camp" which acknowledges the post-colonial context in which camp is performed in Australia and New Zealand. ${ }^{136}$ Examples used in the essay include Crocodile Dundee, Heavenly Creatures, Priscilla, Queen of the Desert, and Sir Robert Muldoon's campy makeup-clad Count Robula character on a television show and role as MC on the stage production of The Rocky Horror Picture Show. ${ }^{137}$ Harnessing the provocations made in 'Antipodean Camp', Matthew Bannister argues that in the New Zealand context, camp could be considered the domain of butch women, in particular Jools and Lynda Topp. ${ }^{138}$ Bannister repurposes Perry's antipodean camp for a uniquely New Zealand context, and proposes instead a framework he dubs 'bush camp'. ${ }^{139}$ More than a cringe worthy double entendre, bush camp concerns itself with what Brady considers the "lesbian/icon" paradox. ${ }^{140}$ While Bannister and Brady disagree on whether or not the utilisation of 'camp' is appropriate in the case of the Topp Twins, both argue that there is something particularly interesting about the Topp Twins, and the wider culture that has grown to accept them. The common denominator in Bannister and Brady's work is gender, and the way it is performed in a New Zealand.

Literature on heritage shows that it is discursively constructed, with dominant discourses often privileging patriarchal and colonial experience. As Hall notes, this ensures that 'Others' do not often see themselves reflected within the products of dominant heritage discourse. ${ }^{141}$ While scholars have taken different approaches to conceptualise and unsettle dominant heritage discourse, their work all centre on the idea that heritage can be used to

\footnotetext{
${ }^{136}$ Perry, 'Antipodean Camp,' Hyperreality and Global Culture, 4-23.

137 Perry, Hyperreality and Global Culture, 5-8, 11, 13.

138 Matthew Bannister, "'Bush Camp"? The Topp Twins and Antipodean Camp,' Australasian Journal of Popular Culture 4, no. 1 (2015): 3-14.

139 Bannister, '“Bush Camp"?,' 11.

140 Bannister, '“Bush Camp”?,' 10-11; Brady, 'Camp Mothers of the Nation?,' 4.

${ }^{141}$ Hall, 'Whose Heritage?'.
} 
perpetuate narratives that exclude those who do not fit so comfortably within national narratives. Similarly, museum studies literature shows that the museum has often been a domain where particular groups are privileged, and others are not. The idea of an authorised, definitive heritage where some a privileged over others is particularly relevant to two exhibitions that both purport to be 'for' or 'of' New Zealand. Scholarship on gender and the museum shows that the museum has traditionally been a space where men are given primacy of place. While this is no longer so overt, recent scholarship shows that there are still plenty of gender disparities within the museum setting. Just as heritage is constructed, so too is national identity. Some scholars argue that discourses of national identity often privilege masculine experience. Literature on New Zealand national identity shows that discourses of gender are embedded within dominant discourses of the nation's identity. This is perhaps most notable in literature looking at 'kiwi bloke' masculinity.

National identity, heritage and gender are all constructed. While looking at dominant discourses can obscure the realities of everyday life and experience, it can also provide a useful entry point into analysis on gender and national identity in the museum. Anita Brady and Matthew Bannister's research on the Topp Twins, gender and New Zealand identity have been incredibly illuminating. ${ }^{142}$ Not only do their subject matter coincide with the subject matter of The Topp Twins, but they also provide a useful frame of analysis for looking at how gender and national identity in New Zealand is performed, subverted and reinforced. Both Bannister and Brady conclude that there is something particularly unique about the relationship between the Topp Twins and New Zealand

142 Bannister, '“Bush Camp"?,'; Brady, 'Camp Mothers of the Nation?,'. 
identity, and question what it says about New Zealand as a nation, that two queer women dressing up in drag can so comfortably fit within the country's character.

Museum and heritage studies literature, along with scholarship on New Zealand identity help to situate the subject matter of this thesis, rugby and the Topp Twins within the context of the key themes of the thesis, national identity and gender. Discourse, gender, heritage, museums, nation, national identity and sports all converge in a variety of different and interesting ways throughout the literature. Here it becomes clear that neither New Zealand national identity and gender, and the Topp Twins and rugby are as different as they may first appear.

The scholarship and theories detailed in this chapter have helped to shape the research in this thesis. The core aim of the thesis is to interrogate the ways national identity and gender converge within the permanent exhibition at the New Zealand Rugby Museum and The Topp Twins exhibition. Underpinning this research are three key questions:

- What is the history and context of the two exhibitions? What is in the exhibitions?

- How is New Zealand national identity and gender narrated and displayed within the two exhibitions?

- What does this say, if anything at all, about the way national identity and gender is exhibited museums? 
The research strategy employed in this thesis is a mixed methods approach. Simply put, according to Martyn Denscombe, a "mixed methods strategy is one that uses both qualitative and quantitative approaches". ${ }^{143}$ A key reason why researchers use mixed methods strategies is because it can "enhance the findings of research by providing a fuller and more complete picture of the thing that is being studied". ${ }^{144}$

In her article, 'Cultural Theory and Museums,' Rhiannon Mason discusses the benefits of textual analysis in museums, along with how this can be done. According to Mason, reading and exhibition or museum like a text, means 'reading' for the exhibition or museum's narrative structures and strategies. ${ }^{145}$ Textual analysis of an exhibition or museum is not simply limited to the exhibition text, as it also includes issues such sound, lighting, experiences of staff, and the institutional politics of the museum. ${ }^{146}$ A great advantage of this kind of research, according to Mason, is that it "moves away from privileging or compartmentalizing a particular aspect of the museum," and shifts away from distinctions of the curator being the 'author' and the visitor being the 'reader'. ${ }^{147}$

Heeding the call to read The Topp Twins exhibition and the New Zealand Rugby widely, the thesis collects data from three main sources, first, the physical elements of the museum including the aesthetic, sound and exhibition text, second via interviews with key people involved in the two exhibitions, and third via historical and contemporary information sourced about the exhibitions from secondary literature, web sources, annual

\footnotetext{
${ }^{143}$ Martyn Denscombe, The Good Research Guide, $3^{\text {rd }}$ edition (Berkshire, UK: Open University Press, 2007), 107.

144 Denscombe, The Good Research Guide, 110.

${ }^{145}$ Rhiannon Mason, 'Cultural Theory and Museum Studies,' in Companion to Museum Studies, ed. Sharon Macdonald (Malden, MA: Blackwell Publishers, 2006), 26.

146 Mason, 'Cultural Theory and Museum Studies,' 26-27.

147 Mason, 'Cultural Theory and Museum Studies,' 27.
} 
reports and news media. The first step of data collection was visiting the two exhibitions, photographing both in their entirety - this included text panels and object labels. Following these visits, the panel and object label text of both exhibitions were then manually written up into two documents. From there, it became possible to 'read' the literal text of the exhibition's multiple times, and search for specific themes and issues. Photographs of the two exhibitions' space and design assisted this reading. After visiting and 'reading' the museums, face-to-face interviews were conducted with four key people involved in either The Topp Twins exhibition or the New Zealand Rugby Museum. The interviews were semi-structured and lasted between one and two hours. The interviews were conversational in nature. A priority for the interviews was understanding the day-today practicalities of the two exhibitions. Getting to understand the pragmatic reality of the exhibitions studies is particularly important according to Mason, as it provides a level of insight that would not be offered simply by reviewing the content of an exhibition. ${ }^{148}$ The interview data proved invaluable in piecing together the chapters below

${ }^{148}$ Mason, 'Cultural Theory and Museum Studies,' 26. 


\section{Chapter Two: The Topp Twins exhibition}

This chapter looks at how and why The Topp Twins ended up on display next to the New Zealand Rugby Museum. The chapter combines interview data with the curator of the exhibition and the Chief Executive of Te Manawa with reports, web information, and news sources. The chapter concludes with an overview of the exhibition, providing a short glimpse into the content and 'feel' of the exhibition. In Chapter Three, a similar approach is taken with the New Zealand Rugby Museum. While Chapter Four is predominantly focussed on the core theme of this thesis, gender and national identity, this chapter, and the one that follows lays important groundwork for exhibition analysis. As discussed earlier in the 'research design' section of Chapter One, it is particularly important to 'read' exhibitions within their wider context. Rhiannon Mason shows that a textual analysis of a museum should include aspects such as lighting, sound, staff, collections, and funding as well as the exhibition narrative. ${ }^{1}$ Examining these features "in concert" is crucial to understanding "possible meanings of the museum" Mason argues. ${ }^{2}$ Importantly, this approach may also highlight "unintentional meanings, omissions, or contradictions present within displays". ${ }^{3}$

\section{The Topp Twins: An Exhibition for New Zealand}

The Topp Twins opened in May 2017 at Palmerston North's Te Manawa museum, and closed in October that same year. ${ }^{4}$ The exhibition has its roots in an earlier exhibition,

\footnotetext{
${ }^{1}$ Rhiannon Mason, 'Cultural Theory and Museum Studies,' in Companion to Museum Studies, ed. Sharon Macdonald (Malden, MA: Blackwell Publishers, 2006), 26-29.

2 Mason, 'Cultural Theory and Museum Studies,' 27.

${ }^{3}$ Ibid.

4 'The Topp Twins: An Exhibition for New Zealand,' Te Manawa, archived in August 2017 via Internet Archive, https://web.archive.org/web/20170810084035/https://www.temanawa.co.nz/topptwin s/.
} 
Topp Twins - Six Strings and Politics, which went on display in July 2012 at the Waikato Coalfields Museum in Huntly, and closed in March 2013. ${ }^{5}$ During the planning stages of the Huntly exhibition, Jane Ferrier, a staff member at the Waikato Coalfields Museum reached out to colleagues at the Waikato Museum in Hamilton for guidance and support, including now CEO of Te Manawa, Andy Lowe. ${ }^{6}$ While the Huntly exhibition was met with enthusiasm, the location and size meant its impact was limited. ${ }^{7}$ During the planning stages of the Huntly exhibition, Lowe, then the Exhibitions Manager and Acting Director at Waikato Museum discussed the viability of expanding the exhibition's scope and making something larger that could tour around New Zealand, with the Twins' manager at Diva Productions. ${ }^{8}$ Lowe's tenure at Waikato Museum ended in 2012 when he moved to Te Manawa. ${ }^{9}$ With him, Lowe brought his vision for a larger Topp Twins exhibition to Palmerston North. Some years later Lowe and his colleagues set out to create The Topp Twins: An Exhibition for New Zealand. ${ }^{10}$ The Topp Twins exhibition was located in the upstairs MacDiarmid gallery at Te Manawa, which has been host to many other temporary exhibitions covering a wide range of subjects from Lego to Frida Kahlo. Entry to the exhibition was free for children under the age of 18 and cost $\$ 5$ for adult admission. After closing in October 2017, The Topp Twins embarked on a national tour. According to the Te Manawa's webpage advertising the tour to potential venues, the exhibition was

\footnotetext{
5 'On exhibition,' Waikato Times, 6 December 2012, 14; 'On exhibition,' Waikato Times, 7 February 2013, 12.

${ }^{6}$ Andy Lowe, interview with author, 2018.

${ }^{7}$ Ibid.

8 Ibid.

${ }^{9}$ Ibid.

${ }^{10}$ Ibid.
} 
available to hire through to $2020 .{ }^{11}$ The first stop on the tour opened in March 2018 at the National Library in Wellington.

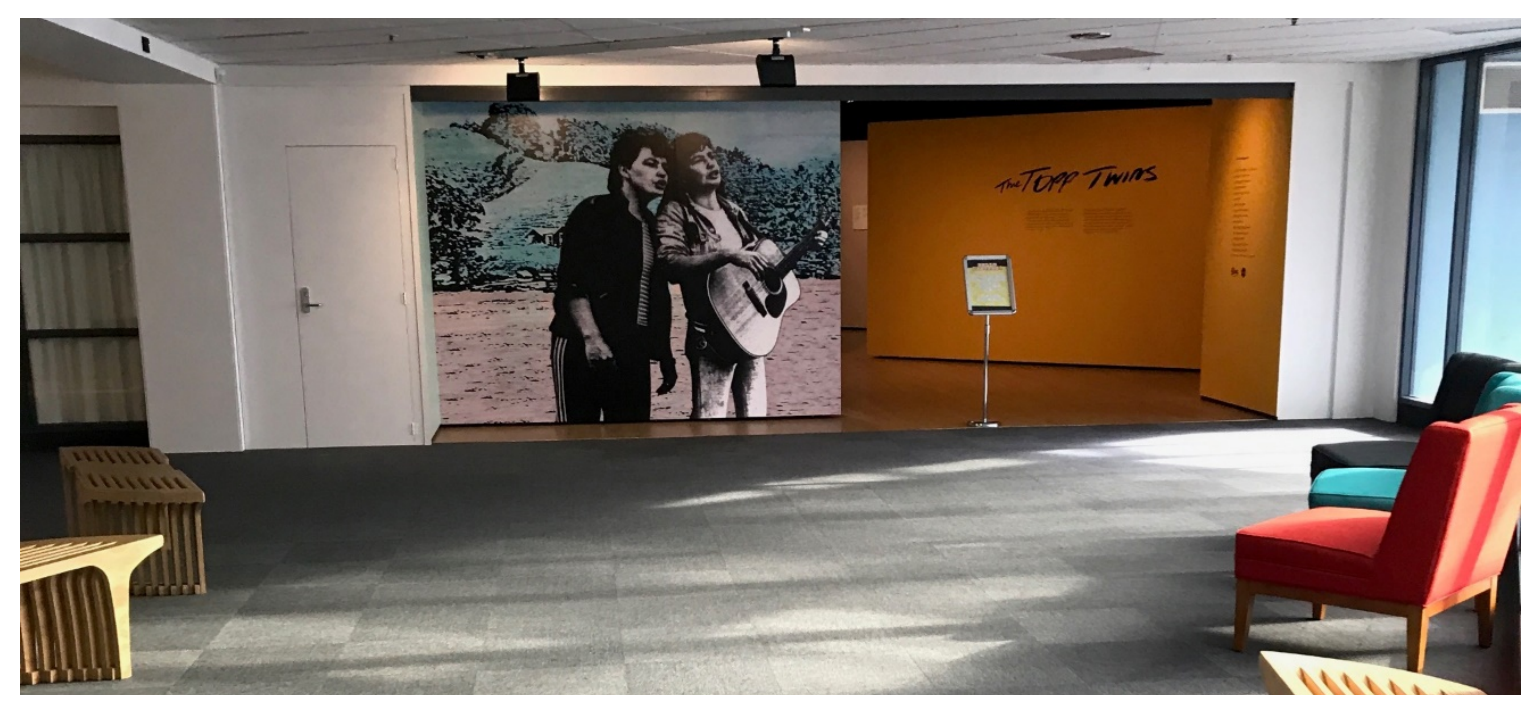

Figure 2. The entrance into The Topp Twins exhibition. Photograph by the author, 2017.

While the Twins' fame and success in New Zealand may be considered reason enough to warrant an exhibition about their lives, in an interview about The Topp Twins, Lowe notes that his own reason for creating the exhibition boils down to the "fantastic kind of magic that happens with the paradox". ${ }^{12}$ The paradox being how two lesbian feminist activists became New Zealand icons. Becoming New Zealand icons was a central theme in Leanne Pooley's 2009 documentary film Untouchable Girls. ${ }^{13}$ The Twins, according to Lowe, represent "the blurred lines between fantasy and reality". ${ }^{14}$ The way the Twins straddle those two worlds where it is difficult to discern "what's what" provided great material for an exhibition. ${ }^{15}$ During the initial planning stages of the exhibition, Lowe opted to

\footnotetext{
11 'The Topp Twins: An Exhibition for New Zealand,' Te Manawa, archived in February 2018 via Internet Archive, https://web.archive.org/web/20180225030144/https://www.temanawa.co.nz/topptwin s/.

${ }^{12}$ Lowe, interview with author, 2018.

${ }^{13}$ The Topp Twins: Untouchable Girls, directed by Leanne Pooley. Rialto, 2009.

14 Lowe, interview with author, 2018.

15 lbid.
} 
contract out the role of curator to Wellington-based artist, Siân Torrington. ${ }^{16}$ Torrington was the sole curator of The Topp Twins; however, a wider team of Te Manawa staff and contractors worked alongside her. ${ }^{17}$ Torrington had not long completed We Don't Have to be the Building, an exhibition in Wellington's Courtney Place light boxes, which commemorated the thirtieth anniversary of Homosexual Law Reform, when Lowe approached her for the project. ${ }^{18}$ Torrington's experience as an artist dealing with queer subjectivities was a key reason Te Manawa contracted her to curate The Topp Twins. ${ }^{19}$ Lowe notes that while it was important that the exhibition came from a queer perspective, it was equally important that the exhibition was curated by someone who, like the Twins, had an artistic background. ${ }^{20}$

Since the first Topp Twins exhibition in Huntly, the Twins' management company Diva Productions had made a large donation of collection items to the Alexander Turnbull Library. In a blog post on the National Library website, the research librarian responsible for making this collection accessible to the public writes that the collection includes "newspaper clippings, press releases, publicity materials, tour schedules, and posters," along with "episode scripts, shooting locations, and hair and make-up requirements" from the Twins' television series. ${ }^{21}$ Torrington notes that her first step in curating the

\footnotetext{
${ }^{16}$ Lowe, interview with author, 2018; Siân Torrington, interview with author, 2018.

${ }^{17}$ Torrington, interview with author, 2018.

18 Lara Lindsay-Parker, 'An Interview with Siân Torrington,' Enjoy, 26 August 2016, archived in May 2018 via Internet Archive, https://web.archive.org/web/20180523013631/http://enjoy.org.nz/blog/2016/08/aninterview-with-sian-torrington.

${ }^{19}$ Torrington, interview with author, 2018; Lowe, interview with author, 2018.

${ }^{20}$ Lowe, interview with author, 2018.

${ }^{21}$ Valerie Love, 'Describing Jools and Lynda,' National Library, September 2014, https://natlib.govt.nz/blog/posts/describing-jools-and-lynda.
} 
exhibition was working through this immense collection. ${ }^{22}$ Torrington approached the archival research as she does her art, via "assemblage" and collage. ${ }^{23}$ Torrington began this process by "group[ing] things together" and "listen[ing] and read[ing]... to see what was being repeated". ${ }^{24}$ Torrington notes that through the repetition in the archives, she was able to see "what seemed important to [the Twins]". ${ }^{25}$ Other than useful materials to include in the exhibition, Torrington took from the Turnbull collection a sense of the Twins' values. ${ }^{26}$ This was something Torrington wanted to "honour" and rearticulate throughout the exhibition. ${ }^{27}$ This included issues such as inclusivity and ensuring "no one is left out," "strong family values," "how [the Twins] treat their fans," "how they make their own music and stay in control of their career". ${ }^{28}$ These elements, Torrington explains, were "weaved into lots of the structure of the exhibition and... events". ${ }^{29}$

\section{Te Manawa - A "Museum without Boundaries"}

Te Manawa is a regional museum in the heart of Palmerston North. It has a long history that dates back to 1906, when the Manawatu Philosophical Society Museum opened. ${ }^{30}$ Although the Manawatu Philosophical Society Museum closed in 1926, many items from its original collection are now housed at Te Manawa. ${ }^{31}$ Throughout the years, Te Manawa, along with its antecedents and collaborators, has taken many forms. Since 1970

22 Torrington, interview with author, 2018.

23 Ibid.

24 Ibid.

25 Ibid.

${ }^{26} \mathrm{lbid}$.

27 Ibid.

$28 \mathrm{lbid}$.

$29 \mathrm{lbid}$.

${ }^{30}$ Fiona McKergow and Kerry Taylor, 'Introduction,' in Te Hao Nui - The Great Catch: Object Stories from Te Manawa, ed. Fiona McKergow and Kerry Taylor (Auckland: Godwit, 2011), 13-14.

31 lbid. 
when the Manawatu Museum opened its doors, gradual changes have been made to the museum's location, space, governance, name, and funding. ${ }^{32}$ Between the mid-1990s and the early 2000s, the museum relocated to its current building, and joined forces with both the Palmerston North Art Gallery Society (now Te Manawa Art Society) and the Science Centre. ${ }^{33}$ By 2002, the museum had been officially renamed Te Manawa and come under the control of the Palmerston North City Council (PNCC). In 2011, Te Manawa underwent refurbishment resulting in the museum space that would be recognisable today. ${ }^{34}$ This is also when Te Manawa and the New Zealand Rugby Museum came to be under the same roof. ${ }^{35}$ The refurbishment included a new space for the New Zealand Rugby Museum upstairs, and three permanent exhibitions that remain on display, Te Rangi Whenua, Manawatū Journeys, and Te Awa - The River: Heart of the Manawatū. ${ }^{36}$

The bulk of Te Manawa's funding comes from an operating grant from the PNCC. For the year ending 30 June 2017 , this amounted to $\$ 3,003,555 .{ }^{37}$ In the same year, Te

\footnotetext{
32 McKergow and Taylor, 'Introduction,' 14-21; 'About,' Te Manawa, archived in February 2018 via Internet Archive, https://web.archive.org/web/20180220035700/https://www.temanawa.co.nz/about/; 'Societies,' Te Manawa, archived in February 2018 via Internet Archive, https://web.archive.org/web/20180220040235/https://www.temanawa.co.nz/about/so cieties/.

${ }^{33}$ McKergow and Taylor, 'Introduction,' 20-21; 'About,' Te Manawa

${ }^{34}$ McKergow and Taylor, 'Introduction,' 20-21.

35 Ibid.

${ }^{36}$ McKergow and Taylor, 'Introduction,' 21; 'Te Rangi Whenua,' Te Manawa, archived in February 2018 via Internet Archive, https://web.archive.org/web/20180220035736/https://www.temanawa.co.nz/event/36 4191/; 'Manawatū Journeys,' Te Manawa, archived in February 2018 via Internet Archive, https://web.archive.org/web/20180220035745/https://www.temanawa.co.nz/event/36 4425/; 'Te Awa - The River - Heart of Manawatū,' Te Manawa, archived in February 2018 via Internet Archive, https://web.archive.org/web/20180220035810/https://www.temanawa.co.nz/event/38 4680/.

${ }^{37}$ Te Manawa Museums Trust, Annual Report, 2016/17, 54.
} 
Manawa received a nominal operating grant from the Manawatu District Council of $\$ 20,000 \cdot{ }^{38}$ Although it is funded predominantly by the city council, Te Manawa maintains a strong regional focus. ${ }^{39}$ According to the chairperson of Te Manawa Museums Trust, John Fowke, the museum is "an integral part of the cultural and social life of the Manawatū region". ${ }^{40}$ In 2013, Te Manawa dubbed itself a "museum without boundaries", but this did not mean a museum without walls or borders. ${ }^{41}$ The tagline "museum without boundaries" has become synonymous with Te Manawa's branding, appearing in official documents and reports, local media reporting, and on the museum's website. ${ }^{42}$ In a post about disability inclusion at Te Manawa on the IHC Foundation blog, Lowe is quoted explaining that a museum without boundaries means "mixing it up and breaking down the barriers. We want to bring people who are often invisible and make them visible in our environment". ${ }^{43}$ In an interview about The Topp Twins, Lowe explains that a museum without boundaries "is really about turning things inside out," where "people, concepts and things that were invisible... and not really respected" are made visible. ${ }^{44}$ The Topp Twins exhibition rests within this plan for a museum without boundaries. Lowe notes that the events surrounding the exhibition, are part of a wider 'community takeover' plan,

\footnotetext{
38 Te Manawa Museums Trust, Annual Report, 2016/17, 54.

${ }^{39}$ Te Manawa Museums Trust, Statement of Intent, 2016/16-2018/19, 6.

40 Te Manawa Museums Trust, Annual Report, 2014/15, 8.

${ }^{41}$ Andy Lowe in Te Manawa Museums Trust, Annual Report, 2015/16, 11.

42 See for example, Janine Rankin, 'Te Manawa aims for a $\$ 58 \mathrm{~m}$ rebuild,' Manawatū Standard, 14 August 2017, https://www.stuff.co.nz/manawatustandard/news/95703371/te-manawa-aims-for-a-58m-rebuild; Janine Rankin, 'Huge task ahead to design a new Te Manawa,' Manawatū Standard, 16 August 2017, https://www.stuff.co.nz/manawatu-standard/news/95703371/te-manawa-aims-for-a58m-rebuild; 'About,' Te Manawa; Te Manawa Museums Trust, Annual Report, 2014/15, 2015/16, 2016/17.

${ }^{43}$ Andy Lowe quoted in 'Open studio brings museum to life,' IHC Foundation, 7 March 2017, archived May 2018 via Internet Archive, https://web.archive.org/web/20180523014526/https://www.ihcfoundation.org.nz/who -we-fund/2017/3/7/open-studio-brings-museum-to-life.

${ }^{44}$ Lowe, interview with author, 2018.
} 
which encourages various community groups and members to take up space within the museum and take ownership of their local museum. ${ }^{45}$

While much of the significance of Te Manawa's museum without boundaries ethos appears to be social, a large part of this seems to also rest in the museum's physical space. Te Manawa is situated in an earthquake prone building, and the facilities and permanent exhibitions have remained unchanged since 2011. In 2017, the museum used the need for earthquake proofing as an opportunity to propose a radical new redevelopment of Te Manawa's buildings and surrounding landscape. Wiremu Te Awe Awe, a local politician and Rangitāne kaumatua ${ }^{46}$ argues that the redevelopment "will further" the mission of a museum without boundaries "and provide an avenue to improve the connection between" the central city and its "creative spaces". ${ }^{47}$ Dubbed "Te Manawa 2025," the proposal to the PNCC puts forward a case for a new museum building, along with some smaller, less expensive modifications that can be made. ${ }^{48}$ Costing for various options range from $\$ 5-7$ million to $\$ 45-58$ million. ${ }^{49}$ The PNCC began deliberating on their contribution towards the redevelopment in 2018. In April 2018, PNCC put redevelopment funding up for public consultation as part of their ten-year plan. Three options were put before the public: contribute $\$ 17.9$ million, contribute a lesser amount, or spent $\$ 4$ million to do bare minimum earthquake proofing. ${ }^{50}$ In June 2018 it was announced that PNCC would put

\footnotetext{
${ }^{45}$ Lowe, interview with author, 2018.

${ }^{46}$ Rangitāne is the local iwi in the Palmerston North area.

${ }^{47}$ Wiremu Te Awe Awe, in Te Manawa Museums Trust, TM2025, April 2018.

${ }^{48}$ Te Manawa Museums Trust, TM2025, August 2017.

49 Janine Rankin, 'Te Manawa rebuild planning gets $\$ 40,000$ boost,' Manawatū

Standard, 28 August 2017, https://www.stuff.co.nz/manawatustandard/news/96217909/te-manawa-rebuild-planning-gets-40000-boost. 50 'Te Manawa 2025 redevelopment,' The Big Picture: Palmerston North City Council, April 2018, archived August 2018 via Internet Archive,
} 
\$463,000 towards “scoping” work necessary to ensure the current Te Manawa 2025 proposals are both costed correctly, and physically achievable. ${ }^{51}$ If the more expensive redevelopment options are selected, it is anticipated that Te Manawa will fundraise the difference. ${ }^{52}$ Separate to Te Manawa 2025 redevelopment, in July 2018 Te Manawa's art gallery building closed for a ten month renovation to "make the 40 -year old building safe and to improve its display areas". ${ }^{53}$ The redevelopment had been allocated $\$ 190,000$ from PNCC.${ }^{54}$ However, in August 2018, in response to outcry from the public and the Palmerston North Art Gallery Society at the length of closure, it was announced that some repairs and upgrades would be done at a later date, including the removal of asbestos in the ceiling. ${ }^{55}$ While the jury is still out on Te Manawa's vision for 2025, the controversy surrounding a $\$ 190,000$ upgrade may signal a difficult future for the museum's bold vision for a museum without boundaries.

\section{The Topp Twins exhibition overview}

The Topp Twins was designed by Lesley Fowler, a very experienced exhibition designer. The exhibition was vibrantly coloured, open, and brightly lit. One of the most noticeable elements of The Topp Twins was the sound. Each section in the exhibition contained at

\footnotetext{
https://web.archive.org/web/20180827082422/https://thebigpicture.pncc.govt.nz/majo r-projects/city-centre-transformation/te-manawa-2025-redevelopment.

51 Jono Galuszka, 'Te Manawa upgrade project gets funds for next steps,' Manawatū Standard, 1 June 2018, https://www.stuff.co.nz/manawatustandard/news/104306187/te-manawa-upgrade-project-gets-funds-for-next-steps. 52 Te Manawa Museums Trust, TM2025, April 2018.

${ }^{53}$ Andy Lowe quoted in Janine Rankin, 'Art Gallery closes temporarily for repairs,' Manawatū Standard, 1 July 2018, https://www.stuff.co.nz/manawatustandard/news/105138761/art-gallery-closes-temporarily-for-repairs. $54 \mathrm{lbid}$.

55 'Art Gallery Renewal Project,' Te Manawa, 20 August 2018, archived August 2018 via Internet Archive https://web.archive.org/web/20180827093729/https://www.temanawa.co.nz/artgaller 步.
} 
least one television screen, which played clips from interviews, the Twins' television show, or the documentary, Untouchable Girls. While some of the television sets had headphones for visitors to put on and listen individually, three played aloud on a loop. No matter where visitors stood in the exhibition, they were likely to be able to hear at least one of the televisions. Most notable was the screen in the "Activism" section, which played a selection of protest songs performed by the Twins. Clips from Untouchable Girls feature heavily throughout the exhibition. Considering both the exhibition and the film are both about the Twins, their rise to fame, career and personal lives, there are many similarities between the two. A key theme in Untouchable Girls is the idea that the Twins' lesbianism and activism should have put them at odds with dominant New Zealand culture, but ultimately did not. The Topp Twins exhibition makes a clear departure from the documentary here. Throughout the exhibition there is little to infer that the Twins' left-wing activism and sexuality could have caused tension with everyday New Zealanders.

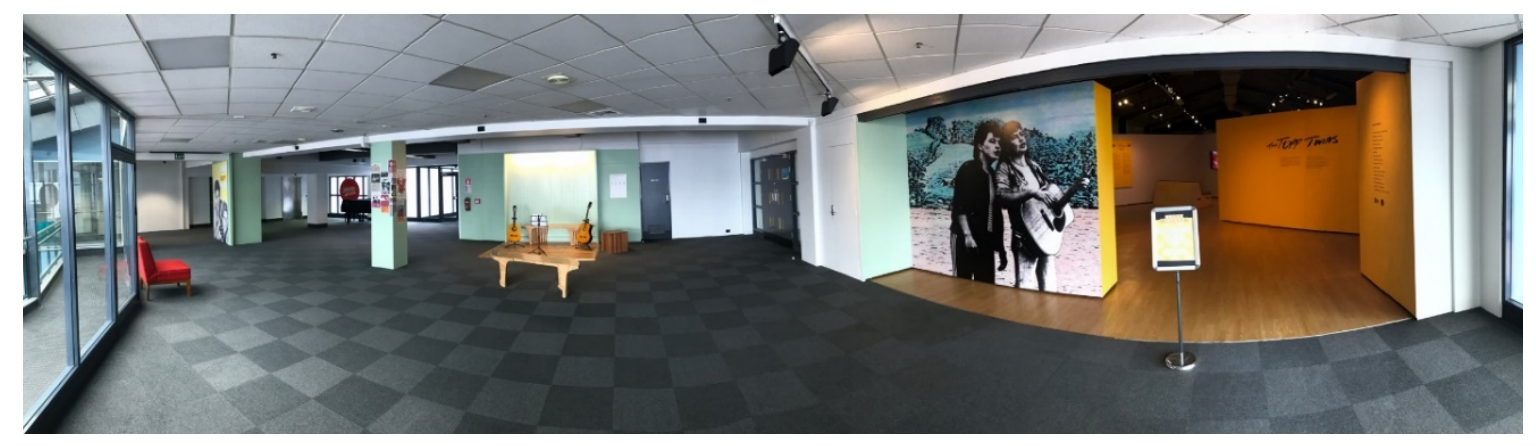

Figure 3. Panoramic image of the foyer separating the New Zealand Rugby Museum and The Topp Twins exhibition. Photograph by the author, 2017.

For curator Siân Torrington, it was important that the exhibition captured the warmth and inclusive nature of the Twins as performers. ${ }^{56}$ Torrington wanted to ensure that the

${ }^{56}$ Torrington, interview with author, 2018. 
exhibition was a "physically comfortable" space. ${ }^{57}$ A good example of Torrington's practice can be seen in the "Love for New Zealand" section of the exhibition where visitors are invited to sit down and watch some of the Twins' television show. Although the exhibition is warm and inviting, as an installation artist, Torrington notes that she "would have gone much further" to make the exhibition feel more like a "lounge," than a gallery. ${ }^{58}$ Andy Lowe explains that while the exhibition captured some of the "comfort" that Torrington was aiming for, it could have been "more comfortable and warm". ${ }^{59}$ Lowe notes that the exhibition was still "very museum-y," which, had there been more time and money. would not have been the case. ${ }^{60}$

Although most of The Topp Twins was displayed within the main gallery upstairs, small snippets of the exhibition spilled outside into the surrounding foyer, including a large display cabinet and a performance space. The cabinet displayed items highlighting the Twins' illustrious career, including film and TV awards, an honorary degree, and photographs with international celebrities. The accompanying interpretation text noted that the Twins have "embodied a good old Kiwi DIY (Do It Yourself) value when it comes to building their own career". ${ }^{61}$ Dotted in between the symbols of the Twins' success were reminders of the less glamorous aspects of their 'DIY' career, like a photograph from a farm variety show, and a tatty country music costume the pair purchased at a second hand store in the 1970s. The performance space was furnished with a small stage, two acoustic guitars, and a music stand with simple chords that visitors

\footnotetext{
57 Torrington, interview with author, 2018.

$58 \mathrm{lbid}$.

${ }^{59}$ Lowe, interview with author, 2018.

$60 \mathrm{lbid}$.

${ }^{61}$ The Topp Twins, Te Manawa Museum of Art, Science and History, Palmerston North, New Zealand.
} 
were invited to try their hand at. Music and dialogue from the exhibition could be easily heard from outside the exhibition in the foyer. The foyer gave the impression that the exhibition, much like the Twins themselves, would be loud, vibrant, and celebratory.

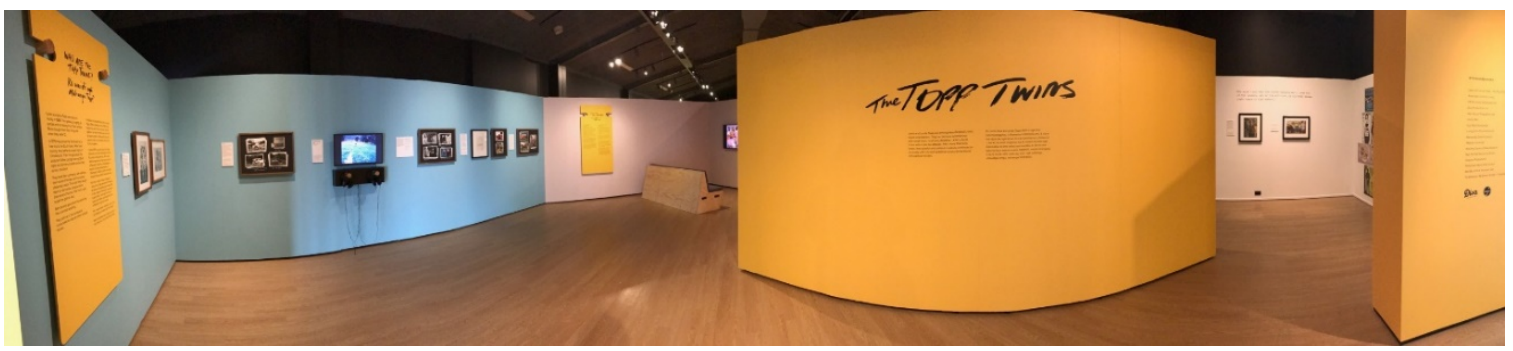

Figure 4. Panoramic image of the entrance of The Topp Twins Exhibition. "Who are the Topp Twins?" can be seen on the left, and the end of "Doin' Alright" can be seen on the right. In the middle, "Love For New Zealand" is visible. Photograph by the author, 2017.

\section{Who are the Topp Twins?}

The opening text of the exhibition introduced the Twins as some of "New Zealand's best loved entertainers," "synonymous with small town, rural New Zealand". ${ }^{62}$ What followed was a section devoted to the Twins' credentials as rural New Zealanders. The section was marked with a wall panel titled "Who are the Topp Twins?" which contained a few short paragraphs of introductory text in both English and Te Reo Māori. ${ }^{63}$ This is a convention that continued in the six sections that followed. "Who are the Topp Twins?" discussed the Twins' early lives, and included photographs of growing up on the farm, their early career playing in bars and coffee houses, and ended with scenes of their rural life in the present. In the middle of this section, there was a small TV screen, that played clips from the 2009 documentary, The Topp Twins: Untouchable Girls, where the Twins recounted their appreciation of growing up in rural New Zealand. ${ }^{64}$ In this section, visitors were

\footnotetext{
62 The Topp Twins, Te Manawa.

63 Ibid.

${ }^{64}$ Pooley, 2009.
} 
introduced to the Twins' influences and motivations - the Twins are, after all "still country girls at heart". ${ }^{65}$

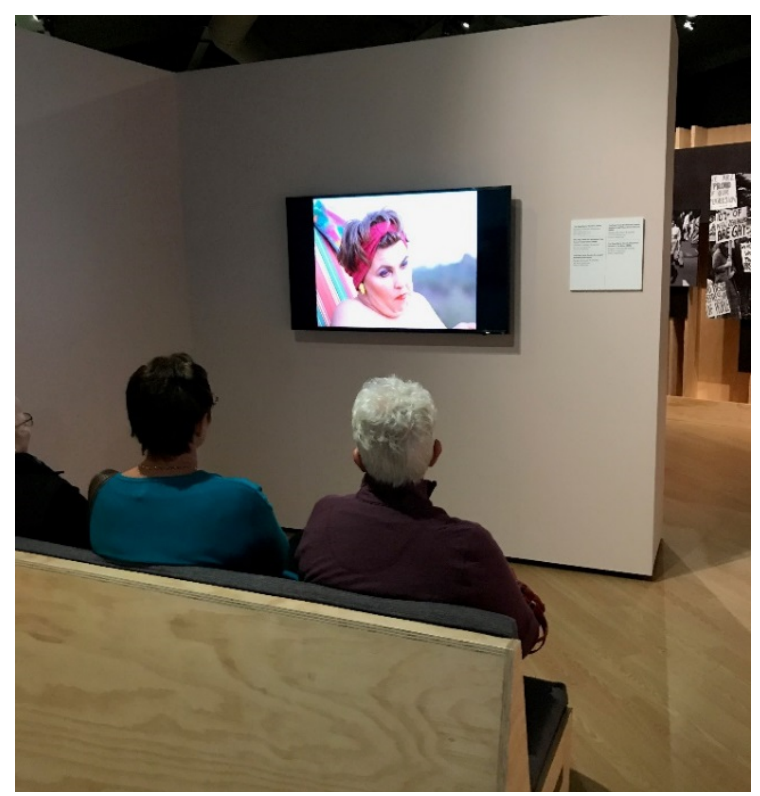

Figure 5. Visitors watching clips from the Twins' television show in "Love for New Zealand". Photograph by the author, 2017.

Love for New Zealand - "Our Hometown is New Zealand"66

The following section in The Topp Twins was "Love for New Zealand". ${ }^{67}$ In this section, the exhibition jumps from the Twins' early lives to their first 'peak' in popularity. Here, a large television and couch encouraged visitors to sit down and watch clips from the Twins' television show, which aired between 1996 and 2000. The premise of the show was that each episode would centre on a uniquely 'New Zealand' event or place. In the show, the Twins, acting as their beloved cast of comedic characters, combined scripted scenes with unscripted interactions with the public at community events to highlight the “quirks" of New Zealand culture. ${ }^{68}$ The footage comprised of clips from five different episodes: Vacation, Speedway, Polo, A\&P Show (Horowhenua), and The Waka. It was because of this television series that the Twins, according to the accompanying wall text,

\footnotetext{
${ }^{65}$ The Topp Twins, Te Manawa.

66 lbid.

67 lbid.

68 Ibid.
} 
"got to be a real part of the New Zealand psyche". ${ }^{69}$ On the opposite wall, clippings from various tabloids and newspapers spanning from 1998 to 2010 further exemplified the extent to which the Twins became a part of the New Zealand psyche. This section insinuates that the Twins' 'love for New Zealand' is a mutual affair.

\section{Becoming the Characters}

After the exhibition introduced the Twins' early life and rise to popularity in New Zealand, it split off into three separate areas. On the left were two sections, "Becoming the Characters" and "On the Road" ${ }^{70}$ Straight ahead there was a section, "Activism," and on the right, two final sections, "Doin' Alright" and "Being Out, Being Ourselves". ${ }^{71}$

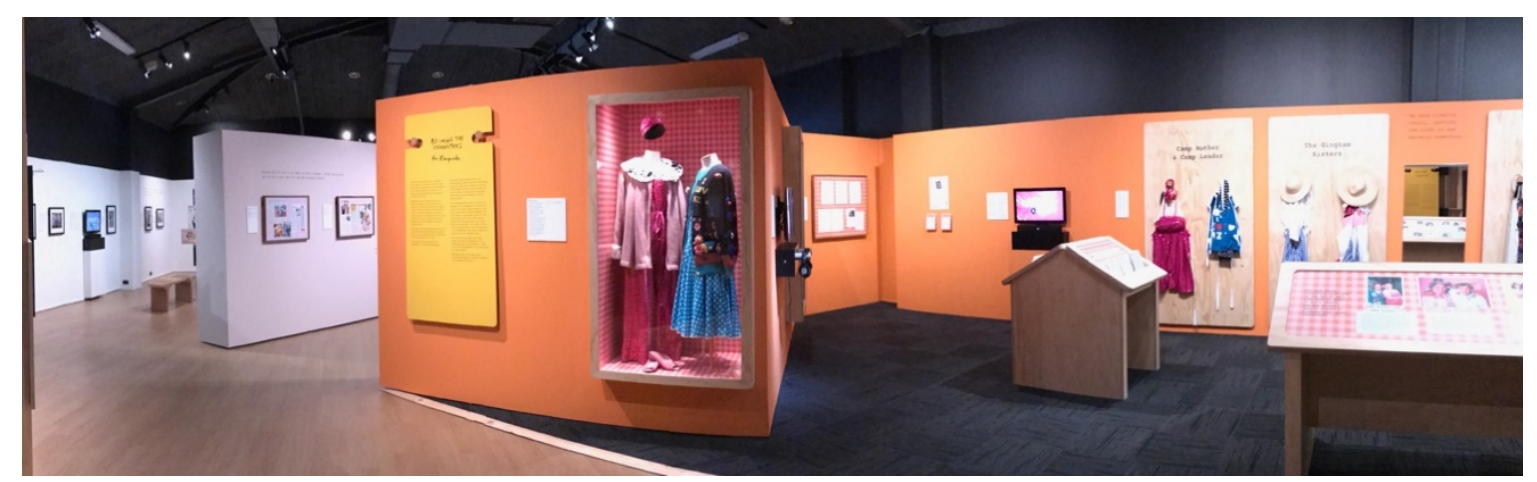

Figure 6. Panoramic image of The Topp Twins exhibition. Pictured on the left is the entrance into "Doin' Alright" and on the right, with the orange walls, is the interactive "Becoming the Characters" section. Note the outfits hanging on the back wall for visitors to try on. Photograph by the author, 2017.

The "Becoming the Characters" section was a large open space with two inbuilt display cabinets, two small television screens, interactive props, and three display tables. ${ }^{72}$ This section introduced the characters that made the Twins a household name in New Zealand. The opening text panel notes that the characters span across "class, gender and culture" in

\footnotetext{
${ }^{69}$ The Topp Twins, Te Manawa.

70 Ibid.

71 lbid.

72 Ibid.
} 
New Zealand. ${ }^{73}$ The characters displayed in this section were Prue and Dilly, wealthy ladies who lunch; Camp Mother and Camp Leader, who run a camping ground and love everything 'kiwi'; Ken and Ken, 'kiwi blokes' from the Wairarapa; Raelene and Brenda, working class best friends from West Auckland; and the Ginghams, poor, rural sisters who love country music. In the cabinets, costumes from the Twins' most popular characters, Ken and Ken and Camp Mother and Camp Leader were displayed. Next to the cabinets, a small television played archival interview footage of the Twins discussing their comedy process. On the opposite wall, another television gave visitors the option to play more clips from the Twins' television show. "Becoming the Characters" gave a glimpse into life behind the scenes of the Twins' television show with ephemera such as casting calls for pet dogs and continuity sheets showing how they were transformed into the characters on display. As the name suggests, "Becoming the Characters" also encouraged visitors to channel their "inner Topp Twin characters" with an assortment of interactive costumes and script cards. ${ }^{74}$ Here, visitors had the opportunity to dress up as some of the Twins' most recognisable characters, and to perform scenes from the television show.

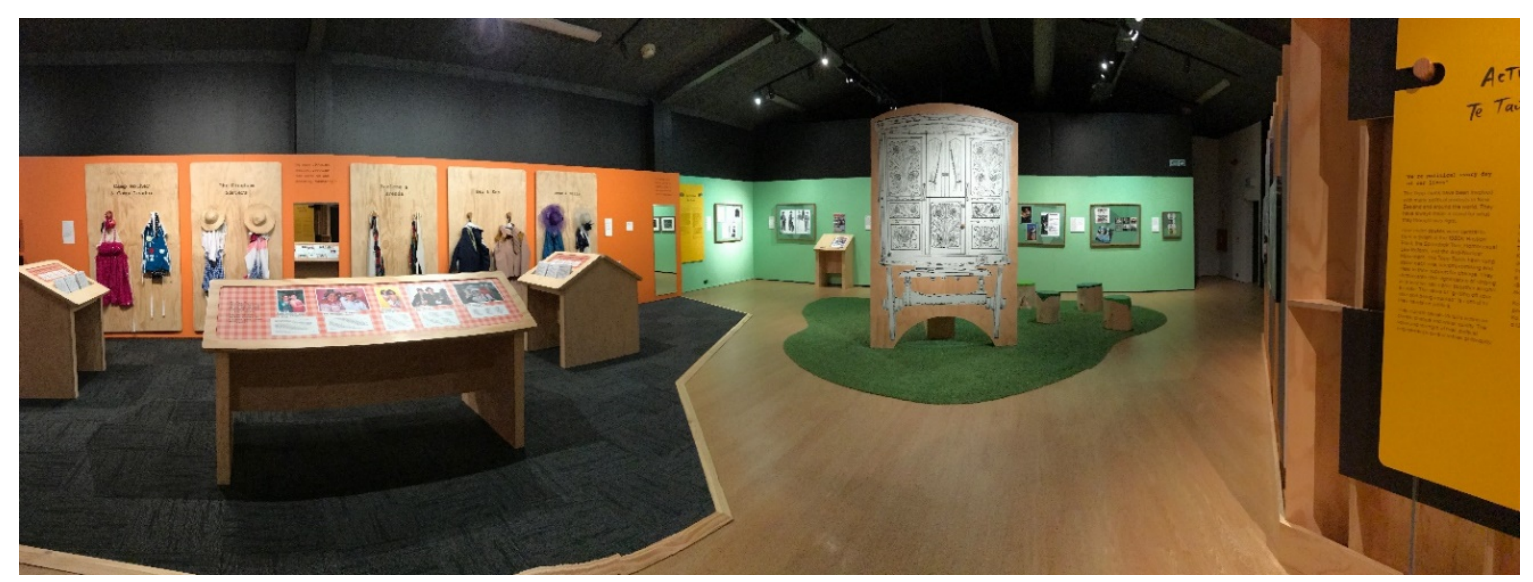

Figure 7. Panoramic image of The Topp Twins exhibition. Pictured on the left with the orange walls, is the interactive "Becoming the Characters" section. Note the outfits hanging on the back for visitors to try on. Toward the right and to the back in green, is the "On the Road" section. Photograph by the author, 2017.

${ }^{73}$ The Topp Twins, Te Manawa.

74 Ibid. 


\section{On the Road}

A large open space with a tall display built to look like an old caravan took up the far corner of the exhibition. As evidenced in earlier sections, the Twins have an intimate relationship with New Zealand and 'the rural'. "On the Road” centred on the Twins' 1989 Gypsy Caravan Tour, where they took to the road in a caravan they built themselves. ${ }^{75}$ As noted in Untouchable Girls, the tour was wildly successful and saw turnouts in small towns that had not been matched since the Royal Tour decades earlier. ${ }^{76}$ Displayed on one side of the model caravan display were mementoes from the Twins' time on the road throughout the years titled "Doing it Ourselves," including handwritten set lists from old international tours, ticket and music sales records, and early poster designs. ${ }^{77}$ On the other side of the caravan, there was a space to sit down and watch documentary footage of the 1989 tour from the film Untouchable Girls. Displayed on the walls surrounding the caravan were photographs from tours and performances over the years - from busking on the streets of central Auckland, to small halls in places like Puhoi, large theatres in London, and music festivals in the United States. This section showed that although the Twins' have an intimate relationship with rural New Zealand, their appeal is widespread.

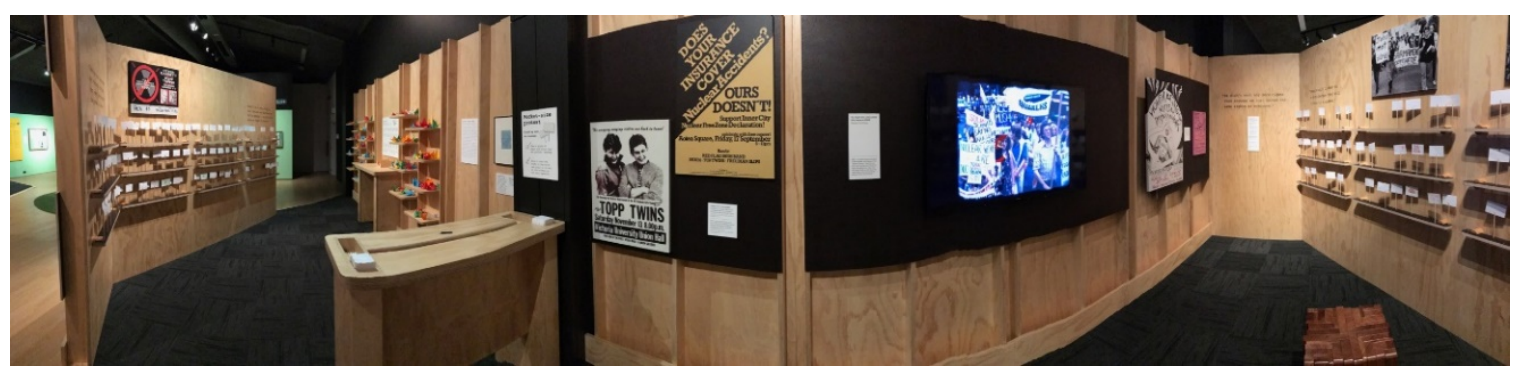

Figure 8. Panoramic image of the "Activism" section. Pictured along the walls are the protest signs made by visitors. Photograph by the author, 2017.

\footnotetext{
75 The Topp Twins, Te Manawa.

76 Pooley, 2009.

77 The Topp Twins, Te Manawa.
} 
Activism

Large prints of photographs from the various protest movements the Twins' involved themselves in surrounded the outside of the "Activism" section - in their own words, "we're political every day of our lives". ${ }^{78}$ Most of the "activism" section was interactive. Visitors had the opportunity to make their own miniature protest signs and display them on shelves. Protest signs varied from support for the Twins and the exhibition, to more political exclamations about issues such as gender identity, the environment, and land rights. Some signs were more abstract, including "save the gay whales", and "more giant flying foxes (please)" ${ }^{79}$ Unfortunately, the signs from the exhibition at Te Manawa were not retained once the exhibition closed, however, as noted in images from the subsequent exhibition at the National Library (figure 9), responses were incredibly varied.
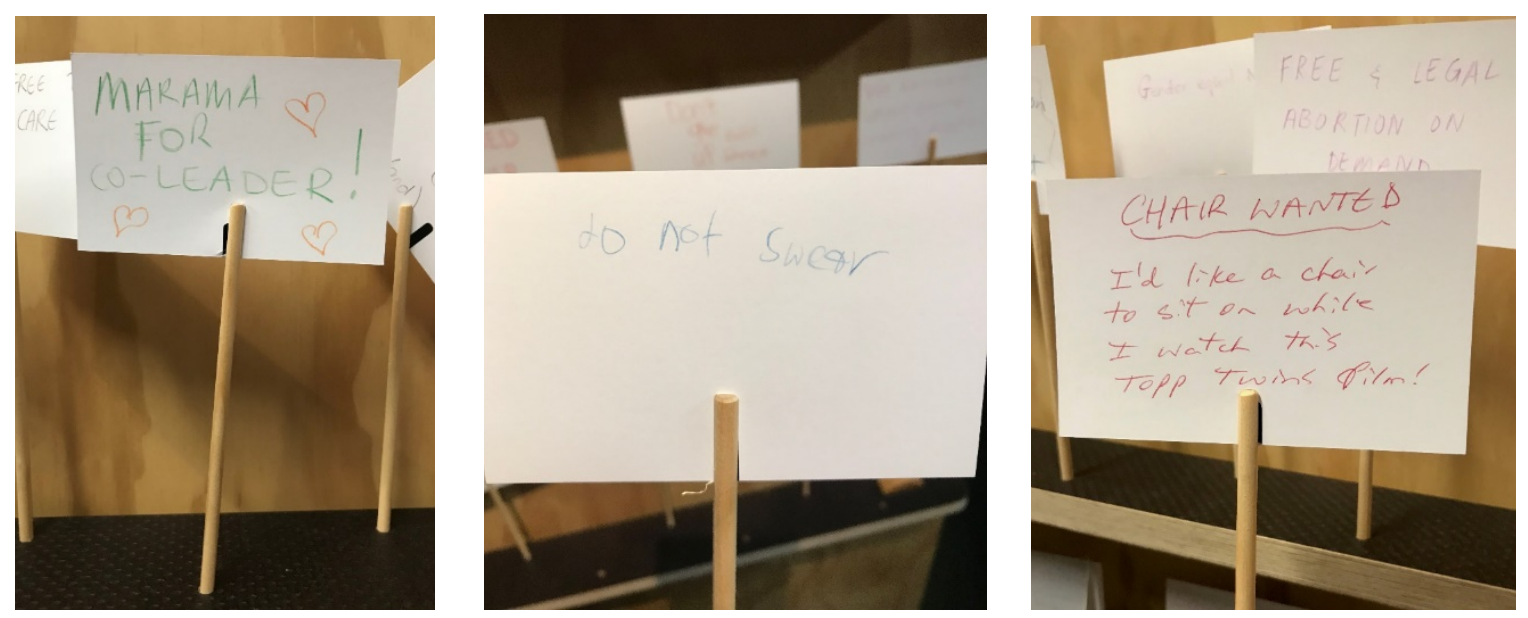

Figure 9. Examples of visitor protest signs from The Topp Twins exhibition at the National Library, Wellington. Photograph by the author, 2018.

Visitors were also invited to fold their own origami peace cranes in acknowledgement of the Twins' involvement in anti-nuclear campaigns. Copies of old protest posters and quotes from the Twins littered the remaining wall space. These included posters

\footnotetext{
78 The Topp Twins, Te Manawa.

79 lbid.
} 
advocating for nuclear disarmament, and anti-establishment quotes printed on the walls such as "when will the pigs ever learn, that one day the system will burn". ${ }^{80}$ The "activism" section showed the radical phase of the beloved entertainers during the 1970s and 1980s protest movements. Beside the protest signs and posters, a television played clips from Untouchable Girls where the Twins' recount their involvement in some of the nation's most polarising demonstrations during the 1970s and 1980s. In the clips, the Twins recall the tension within their own family when they decided to join protestors during the Springbok Tour, and perform old Bastion Point protest songs with seasoned activist Mereana Pitman. While the protest movements the Twins involved themselves in are less divisive now for a variety of reasons, the clips from Untouchable Girls show that this was not always the case.

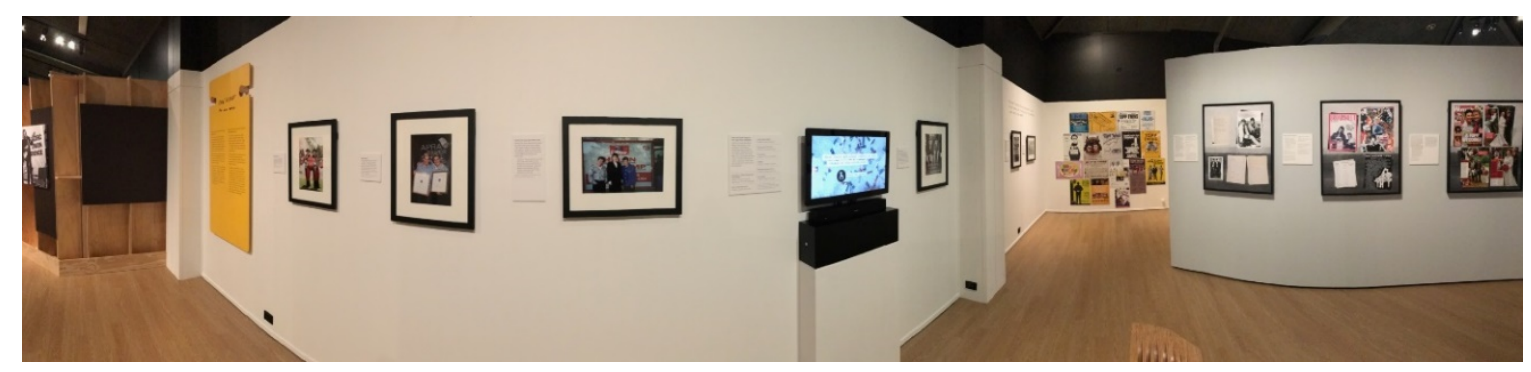

Figure 10. Panoramic image of The Topp Twins exhibition. Pictured on the left is the "Doin' Alright" section, and on the right, the final three displays from "Being Out, Being Ourselves". Photograph by the author, 2017.

\section{Doin' Alright}

The final two sections were dedicated to the Twins' achievements and their involvement in queer politics. In 'Doin' Alright," the section highlighted some of the Twins' greatest accolades. This included an honorary doctorate from the University of Waikato in 2011, being inducted into the New Zealand Music Hall of Fame in 2008 and rubbing shoulders with "many well-known people" including former Prime Minister Helen Clark. ${ }^{81}$ The

\footnotetext{
80 The Topp Twins, Te Manawa.

$81 \mathrm{lbid}$.
} 
section also paid attention to Jools Topp's battle with cancer in 2006, and subsequent awareness campaigns the Twins have participated in. "Doin' Alright" highlighted the Twins' success within a uniquely New Zealand context. The opening text was a direct quote from the Twins where they noted that, "we don't aspire to drive around in limousines. As long as we've got enough money to feed the dogs, pay the rent - that's how we feel that we've made it. That's success to us". ${ }^{82}$ This section also included a television screen where visitors could listen to snippets from an oral interview conducted by Torrington with the Twins. Here the Twins speak to each section of the exhibition and what it means to them, emphasising the importance of humility, and loyalty to New Zealand - a theme that ran through the entire exhibition.

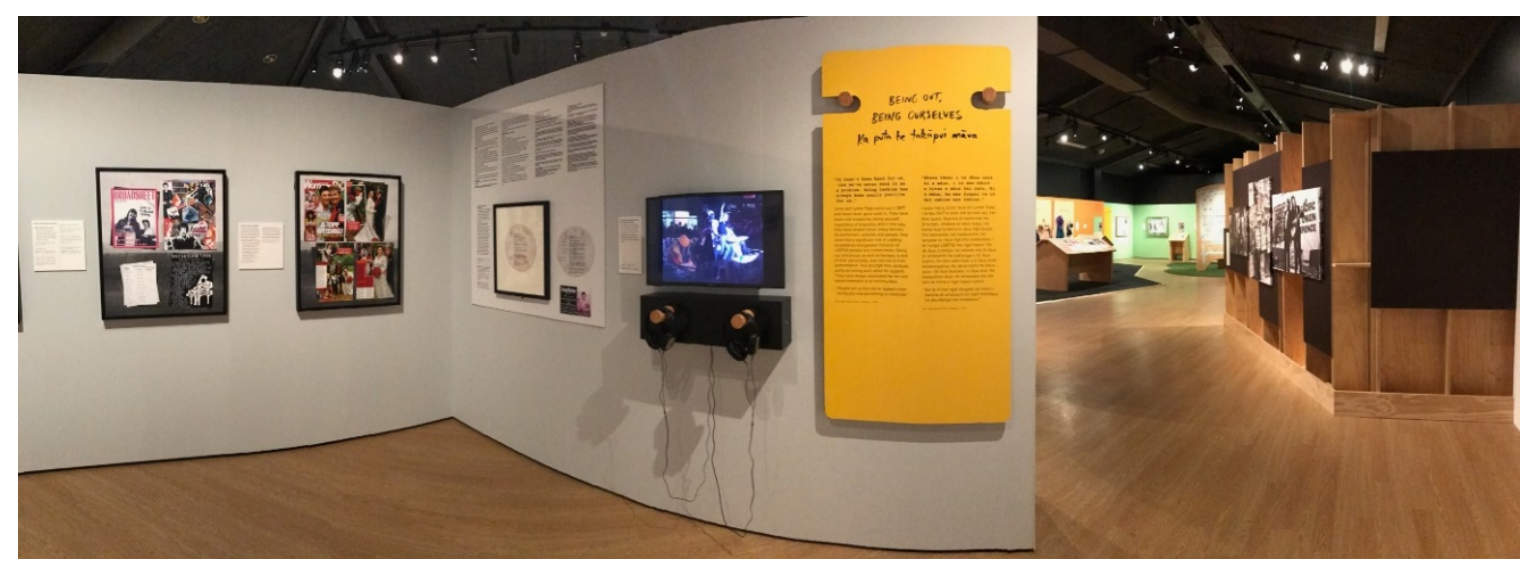

Figure 11. Panoramic image of The Topp Twins exhibition. Pictured in the foreground to the left, is the "Being Out, Being Ourselves" section, and on the right, a glimpse into the rest of the exhibition, including the outside walls of the "Activism" section. Photograph by the author, 2017.

\section{Being Out, Being Ourselves}

In the section "Being Out, Being Ourselves," the exhibition explored the Twins" "role in creating acceptance and greater inclusion of LGBQI people" by being 'out' in public since $1977 .{ }^{83}$ The first part of this section was a television that played clips from Auckland's 1997 gay pride parade, dubbed the 'Hero Parade'. The parade was televised

\footnotetext{
82 The Topp Twins, Te Manawa.

83 lbid.
} 
on TV3 and hosted by Anita McNaught and the Twins dressed in character as 'typical kiwi blokes', Ken and Ken. The premise of the coverage is that Ken and Ken think the hero parade is a celebration of New Zealand heroes like the All Blacks and Sir Ed Hillary. The footage showed the comedy that unfolds as Ken and Ken slowly begin to realise the parade is celebrating a 'different' kind of hero. The politics of Auckland's pride parade continued into the next part of the section, where the exhibition explored Lynda Topp's campaign for Auckland mayoralty in 1998. Lynda, in character as Camp Mother, launched a campaign against incumbent Les Mills, who "wanted to shut down the Hero Parade". 84 "Being out, being ourselves" featured a large display of a campaign speech delivered the Camp Mother, and various election ephemera. The final part of this section showed various clips from posters and magazines, including a poster from the feminist music festival, the controversial Michigan Womyn's Festival ${ }^{85}$, to the cover of New Zealand feminist magazine, Broadsheet and a spread covering Lynda's marriage to wife Donna in 2013 during the campaign for marriage equality in New Zealand Women's Weekly.

\section{Public programmes}

During The Topp Twins' time at Te Manawa, the museum organised a variety of events to supplement the exhibition. The museum held four public talks relating to the exhibition. Nicholas Holm, a media studies lecturer at Massey University, delivered a talk called "Querying Comedy" where he explored the way the Twins are "using comedy to unsettle

\footnotetext{
${ }^{84}$ The Topp Twins, Te Manawa.

${ }^{85}$ After years of protest over the festival's transphobic "womyn-born womyn" only policy, the festival eventually shut down in 2014. See for example, Diana AndersonMinshall, 'Michfest's Founder Chose to Shut Down Rather Than Change with the Times,' Advocate, 24 April 2015, https://www.advocate.com/commentary/2015/04/24/op-edmichfests-founder-chose-shut-down-rather-change-times.
} 
ideas around gender, sexuality and what it means to be a New Zealander". ${ }^{86}$ Victoria University media studies lecturer, Anita Brady similarly delivered a talk "True Blue Boys: The Topp Twins and New Zealand identity," which explored the ways the Twins cross gender boundaries, and consequently unsettle tropes about New Zealand identity. ${ }^{87}$ Keri Cheetham, an early childhood education lecturer at Massey University, and Maree Brannigan from the Institute of Education at Massey University, delivered a talk looking at what it means to be a twin in a talk "Twin Psychology from Birth to Adulthood" ${ }^{88}$ The final talk was a panel organised by Rural Women New Zealand, which sought to "celebrate the women of our countryside". ${ }^{89}$ Te Manawa also hosted a Kiwiana Quiz night, and an event "Smash the Ceiling: Finding Equality in the Local Music Scene" which included discussion of women's involvement in New Zealand music to align with the exhibition. ${ }^{90}$

86 'Querying Kiwi Comedy,' Eventfinda, archived in February 2018 via Internet Archive, https://web.archive.org/web/20180228022444/https://www.eventfinda.co.nz/2017/to pp-twins $2 /$ palmerston-north.

87 'True Blue Boys: The Topp Twins and New Zealand identity,' Eventfinda, archived in February 2018 via Internet Archive, https://web.archive.org/web/20180228022855/https://www.eventfinda.co.nz/2017/tru e-blue-boys-the-topp-twins-and-new-zealand-identity2/palmerston-north.

88 'Twin Psychology from Birth to Adulthood,' Eventfinda, archived in February 2018 via Internet Archive, https://web.archive.org/web/20180228022612/https://www.eventfinda.co.nz/2017/pu blic-talk-twin-psychology-from-birth-to-adulthood/palmerston-north.

89 'Public Talk: Rural Women of New Zealand,' Eventfinda, archived in February 2018 via Internet Archive, https://web.archive.org/web/20180228022825/https://www.eventfinda.co.nz/2017/pu blic-talk-rural-women-of-new-zealand/palmerston-north.

90 'Smashing the Ceiling: Finding Equality in the Local Music Scene,' Eventfinda, archived in February 2018 via Internet Archive, https://web.archive.org/web/20180228022754/https://www.eventfinda.co.nz/2017/so ngwriters-circle/palmerston-north. 
While not explicitly related to the exhibition, there were a wide array of other events that happened at Te Manawa during The Topp Twins' tenure that grappled with related subject matter. The opening of The Topp Twins exhibition coincided with the Museums Aotearoa annual conference. The conference was themed 'museums of inclusion', and delegates were encouraged to visit the exhibition and the neighbouring Rugby Museum free of charge. The Charlotte Museum, which collects artefacts relating to lesbian life, also had a pop-up museum in the events room next door to The Topp Twins during the conference. In 2017, Te Manawa signed a memorandum of understanding with Manawatu Lesbian and Gay Rights Association (MALGRA), which granted MALGRA access to Te Manawa's facilities for meetings and events. During the course of the exhibition, MALGRA held a masquerade ball, and a drag workshop at Te Manawa.

\section{$\underline{\text { Summary }}$}

The Topp Twins was borne out of the idea that the Huntly exhibition could be improved upon, made larger, and toured around New Zealand. From the outset, The Topp Twins was commissioned and created as an exhibition that could be displayed nationally, not just in provincial New Zealand. In anticipation of the work this required, Te Manawa sought out a queer freelance artist who had little to do with the day-to-day issues of the museum. It was important that The Topp Twins was curated by someone who could approach the exhibition from a particular viewpoint. Beyond the specifics of The Topp Twins exhibition, Te Manawa is a museum currently battling to get the funding to modernise and redefine its role within its local community. As a museum without boundaries, Te Manawa has sought to be more inclusive and community minded with its exhibition line-up and its plans for the building in the future. The Topp Twins is a part of these efforts. Looking at the wider exhibition context, it is possible to find more nuanced 
ways to approach the ways gender and national identity are produced, subverted and reinforced within a museum. 


\section{Chapter Three: The New Zealand Rugby Museum}

Unlike The Topp Twins at Te Manawa, the New Zealand Rugby Museum is an entire museum with a permanent exhibition, which has been open, with minimal modifications, since 2011. The museum is located on the upstairs level of the Te Manawa museum complex but is a completely separate organisation. The museum is ticketed, costing $\$ 12.50$ for adults, $\$ 5.00$ for children, and $\$ 30.00$ for a family group. The exhibition area is split into four sections - the "The Discovery Library," a well-stocked rugby research library; the "Rugby Relics" gallery, the major exhibition documenting rugby from its "ancient beginnings" through to 2011; the "Rugby Tribe" gallery, a small rotating gallery; and the "Have a Go" area, an interactive section where children can test their rugby skills. The museum and its collection is owned and managed by the Rugby Museum Society of New Zealand, which was formed in 1969 by rugby enthusiast, John Sinclair and historian Dr Fred Spurdle. ${ }^{1}$ Before founding the museum, Sinclair was known for organising tours to follow the All Blacks on international tours. ${ }^{2}$ There, Sinclair gained access to players and officials and began to accumulate a wide variety of souvenirs and keepsakes. ${ }^{3}$ Upon returning from the All Blacks tour of Britain, France and Canada in 1967, Sinclair attempted to gift the collection he had accumulated on his travels to the New Zealand Rugby Union. ${ }^{4}$ The gift was declined, and Sinclair was told to find somewhere else to display the memorabilia. Soon after, the Rugby Museum Society of New Zealand was formed in Palmerston North where Sinclair and Spurdle resided. ${ }^{5}$ The society is a

\footnotetext{
${ }^{1}$ Stephen Berg, interview with author, 2018; Peter Lampp, 'Rugby Museum Founder a Visionary,' Manawatū Standard, 21 March 2013, http://www.stuff.co.nz/manawatustandard/sport/8454661/Rugby-Museum-founder-a-visionary.

2 Berg, interview with author, 2018.

${ }^{3}$ Ibid.

4 Berg, interview with author, 2018; Lampp, 'Rugby Museum Founder a Visionary.'

${ }^{5}$ Berg, interview with author, 2018.
} 
membership organisation, currently touting over 700 members. ${ }^{6}$ The museum has a paid director, Stephen Berg, who is responsible for the day-to-day business and leadership, while a committee oversees the museum's governance. ${ }^{7}$

The museum opened to the public in 1977, and at the time, the museum's mandate was to build an "internationally significant" collection. ${ }^{8}$ With a collection of over 40,000 items, the main role of the museum is defined as "to be the official Rugby Museum in New Zealand that safeguards the preservation, protection and display of the history and heritage of New Zealand". ${ }^{9}$ Before moving into its first building in 1977, the museum would often put up small displays in public places. ${ }^{10}$ The museum's inaugural display was in April 1969 at the Palmerston North Plaza. The museum plans to commemorate the fiftieth anniversary of this display in 2019. ${ }^{11}$ The museum had two prior locations before moving into the Te Manawa complex in 2011.12 Although the museum believed it had achieved its goal of an 'internationally significant' collection prior to 2011, museum curator Bettina Anderson remarks that previous locations were small, and collections were loosely displayed around disparate themes. ${ }^{13}$ Moving into Te Manawa in 2011 was a great opportunity for the museum to sort through its collections, and create a more professional space to display their collection. ${ }^{14}$ The redevelopment was curated by Bettina Anderson, who was supported by a team including museum director Stephen Berg and

\footnotetext{
${ }^{6}$ Berg, interview with author, 2018.

7 Berg, personal interview, 2018; 'About Us,' New Zealand Rugby Museum.

8 'About Us,' New Zealand Rugby Museum.

${ }^{9}$ Ibid.

${ }^{10}$ Berg, interview with author, 2018.

11 lbid.

12 lbid.

${ }^{13}$ Berg, interview with author, 2018; Bettina Anderson, interview with author, 2018.

${ }^{14}$ Berg, interview with author, 2018.
} 
rugby historian Clive Ackers. ${ }^{15}$ Anderson was a freelance museum consultant, and had previously worked at Te Manawa. ${ }^{16}$ Her exhibition experience paired well with Ackers' "encyclopedic" knowledge of rugby history, and Berg's knowledge of the museum and its collection. ${ }^{17}$ The exhibition text was fact checked by rugby historian Ron Palenski and rugby commentator Keith Quinn, and others were consulted when needed. ${ }^{18}$

The Rugby Museum's relocation and redevelopment was completed in line with a planned renewal of Te Manawa, and the 2011 Rugby World Cup. ${ }^{19}$ The Rugby Museum has an entire section dedicated to the 2011 World Cup, and opened just in time to engage a captive audience of world cup tourists. ${ }^{20}$ The museum's website notes that the redevelopment heralded a new "catch-cry" for the museum: "the sport that shaped a nation". ${ }^{21}$ Since the new museum displays opened in 2011, only a few minor changes have been made to its permanent exhibition. ${ }^{22}$ Most recently, display drawers have been added below some of the cabinets, to add in perspectives that are missing from the original exhibition. ${ }^{23}$ The museum gathers most of its revenue from ticket sales, an operating grant from New Zealand Rugby, and small one off grants. ${ }^{24}$ Along with grants, the museum's rent and utilities are also covered by the PNCC. ${ }^{25}$ In an interview about the museum, Berg, the only full time employee at the museum, notes that despite help from

\footnotetext{
${ }^{15}$ Berg, interview with author, 2018; Anderson, interview with author, 2018.

${ }^{16}$ Anderson, interview with author, 2018.

17 Ibid.

$18 \mathrm{lbid}$.

${ }^{19}$ Berg, interview with author, 2018.

20 lbid.

21 'About Us,' New Zealand Rugby Museum.

${ }^{22}$ Berg, interview with author, 2018; Anderson, interview with author, 2018.

23 Ibid.

${ }^{24}$ Berg, interview with author, 2018.

25 Ibid.
} 
New Zealand Rugby and the PNCC, they have an incredibly tight operating budget. ${ }^{26}$ As such, the museum relies heavily on volunteers to run the front of house. ${ }^{27}$ In part this stems from costs associated with the 2011 renewal. ${ }^{28}$ Berg explains that the museum did not raise enough funds to cover the cost of the new space. ${ }^{29}$ Facing a deficit of around $\$ 350,000$, the museum had to take out a $\$ 200,000$ loan from the PNCC at $7 \%$ interest. $^{30}$ While the loan has since been paid off, the museum continues to operate on a tight budget. ${ }^{31}$ Consequently, additions to the museum need to be considered carefully. ${ }^{32}$

Two of the most pressing issues for the museum currently relate to funding and what Berg describes as "going national". ${ }^{33}$ The permanent exhibition is a chronological display, spanning from the 1860 s through to 2011 . Berg notes that the museum would like to continue the chronology into the present decade and beyond. New cabinets to extend the exhibition chronology will cost the museum over $\$ 100,000$, which is a significant expense for the museum. The new cabinets will also be difficult to populate, as the cost of acquiring objects like jerseys from star players has become an incredibly costly and difficult endeavour. ${ }^{34}$ Although the museum will likely opt for this extension, Berg also needs to consider the future of the earthquake prone Te Manawa building, and the associated costs with Te Manawa 2025. ${ }^{35}$ Both are currently unknown. Aside from financial constraints, Berg explains that while the museum is a national museum, it often

\footnotetext{
${ }^{26}$ Berg, interview with author, 2018.

27 lbid.

$28 \mathrm{lbid}$.

$29 \mathrm{lbid}$.

${ }^{30} \mathrm{lbid}$.

$31 \mathrm{lbid}$.

32 Ibid.

33 lbid.

${ }^{34} \mathrm{lbid}$.

$35 \mathrm{lbid}$.
} 
had a tendency towards insularity. ${ }^{36}$ Berg notes that the museum also attracts a predominantly international audience. ${ }^{37}$ Going national, for Berg, means not just getting more visitors from New Zealand through the door, but tying in with rugby events around the country, and facilitating a broader engagement with the museum's collection and rugby history. ${ }^{38}$ As part of the centenary of World War One, the museum applied for and received Lotteries funding to produce a touring exhibition, Balls, Bullets and Boots. ${ }^{39}$ The exhibition has been touring for three years, and will eventually close in $2019 .{ }^{40}$ Producing touring shows is something Berg would like to do more of, particularly considering the current constraints of the museum's exhibition space. ${ }^{41}$ Recent efforts to broaden the reach of the museum include a "rugby jamboree" held in May $2018 .{ }^{42}$ The jamboree brought together rugby enthusiasts, historians and players for a weekend of talks, displays and networking. ${ }^{43}$ Berg hopes to plan more events like the jamboree around the country. ${ }^{44}$

\section{$\underline{\text { Rugby Relics exhibition overview }}$}

Up to this point, this chapter has considered the museum in its entirety. The focus of the exhibition overview, however, will be on the "rugby relics" gallery. This is because the

\footnotetext{
${ }^{36}$ Berg, interview with author, 2018.

${ }^{37}$ Ibid.

38 lbid.

39 In November 2013, the Minister of Internal Affairs and the Minister for Arts, Culture and Heritage announced $\$ 2.7$ million in funding by the New Zealand Lottery Grants Board towards projects relating to the centenary of World War One. See: Minister of Internal Affairs, Chris Tremain and Minister for Arts, Culture and Heritage, Chris Finlayson, Diverse funding for World War One Centenary, 2013, https://www.beehive.govt.nz/release/diverse-funding-world-war-one-centenary.

${ }^{40}$ Berg, interview with author, 2018.

${ }^{41} \mathrm{lbid}$.

42 Ibid.

43 'Rugby Jamboree,' Eventfinda, archived in August 2018 via Internet Archive, https://web.archive.org/web/20180821114926/https://www.eventfinda.co.nz/2018/ru gby-jamboree/palmerston-north.

${ }^{44}$ Berg, interview with author, 2018.
} 
"rugby tribe" gallery has changed since research for this thesis commenced, and as such, it has been difficult to keep track of everything that has been displayed. For example, during the British and Irish Lions Tour, 3 June -8 July 2017, the gallery was fitted out to display various collection items relating to the team and their time in New Zealand throughout the years. It is also because of the sheer size of the museum's content. Although the Rugby Museum space is a similar size to The Topp Twins, the rugby relics gallery is far more populated with objects and contains significantly more exhibition text. Thus, it is not possible to describe in detail everything contained within the gallery.

The Rugby Museum's exhibition space was designed by a contractor, in liaison with curator Bettina Anderson and the exhibition team. ${ }^{45}$ When visitors walk into the museum, they are greeted by a museum volunteer at a mock turnstile gate common in sports stadiums. The museum space is expansive and open, with large cabinets lined up against both the left and right walls. These cabinets comprise of the rugby relics gallery, while the "have a go" and "rugby tribe" sections are situated in the middle of the museum space. The museum has an 'industrial' look, with the metal cabinet frames and ceiling beams being a prominent feature of the space. Berg notes that the wide beams in the space influenced the exhibition design, describing the overall space as having a "crystal palace" feeling about it. ${ }^{46}$ The crystal palace influence gives the exhibition a slightly

\footnotetext{
${ }^{45}$ Anderson, interview with author, 2018.

${ }^{46}$ Berg, interview with author, 2018; The Crystal Palace was an expansive building made of glass and iron, designed to house the Great Exhibition of 1851 in London. The Exhibition had an incredible influence on British society at the time, and remains an important facet of museum history. The Crystal Palace building set a standard for exhibitions in subsequent years, with glass, and wide, open space becoming a common feature. See: 'The Great Exhibition,' Victoria and Albert Museum, archived in February 2018 via Internet Archive, https://web.archive.org/web/20180207221907/http://www.vam.ac.uk/page/g/greatexhibition/.
} 
serious, erring on the side of sombre, appearance. The seriousness of the space is tempered with the sound of old rugby games being played in the entrance. The rugby relics cabinets are expansive, containing a wide variety of objects and ephemera. Berg explains that they "wanted to make the cabinets look like they came from... Victorian England". ${ }^{47}$ According to Anderson, in some instances it was incredibly difficult to populate the cabinets, as most of the museum's collection are "two dimensional paper based ephemera" ${ }^{48}$ Anderson notes that most of the three dimensional collection items had already been on display at the old museum. ${ }^{49}$ A large bulk of the work in designing the cabinets was finding suitable material to supplement existing collection items, and finding ways to display paper-based ephemera creatively. ${ }^{50}$ The cabinets are displayed in chronological order. Anderson notes that chronological display seems like common practice in social history exhibitions, and in the case of the Rugby Museum, chronology was a logical fit for the space. ${ }^{51}$

The rugby relics gallery focusses predominantly on rugby throughout the decades however, some space is dedicated to other themes and issues. These include two wall panels looking at the origins of haka, and the haka most commonly associated with the All Blacks; a large map of World Rugby affiliated countries; a cabinet filled with rare collectors' items, including one of the first black jerseys with a silver fern; and retrofitted drawers installed underneath some displays, that include small displays on women's rugby (see figure 12), uniforms and other interesting events previously missed out by the exhibition. Anderson notes that the drawers were an opportunity to "add humour" into an

\footnotetext{
${ }^{47}$ Berg, interview with author, 2018.

${ }^{48}$ Anderson, interview with author, 2018.

49 Ibid.

${ }^{50}$ Anderson, interview with author, 2018; Berg, interview with author, 2018.

${ }^{51}$ Anderson, interview with author, 2018.
} 
otherwise 'serious' exhibition. Dotted in between most of the large cabinet displays are smaller text panels with a set of four short snippets about New Zealand history. ${ }^{52}$ Anderson explains that these provided needed historical context to the exhibition, reflecting the idea that "what was happening in rugby... kind of reflects what was happening in New Zealand" too. ${ }^{53}$

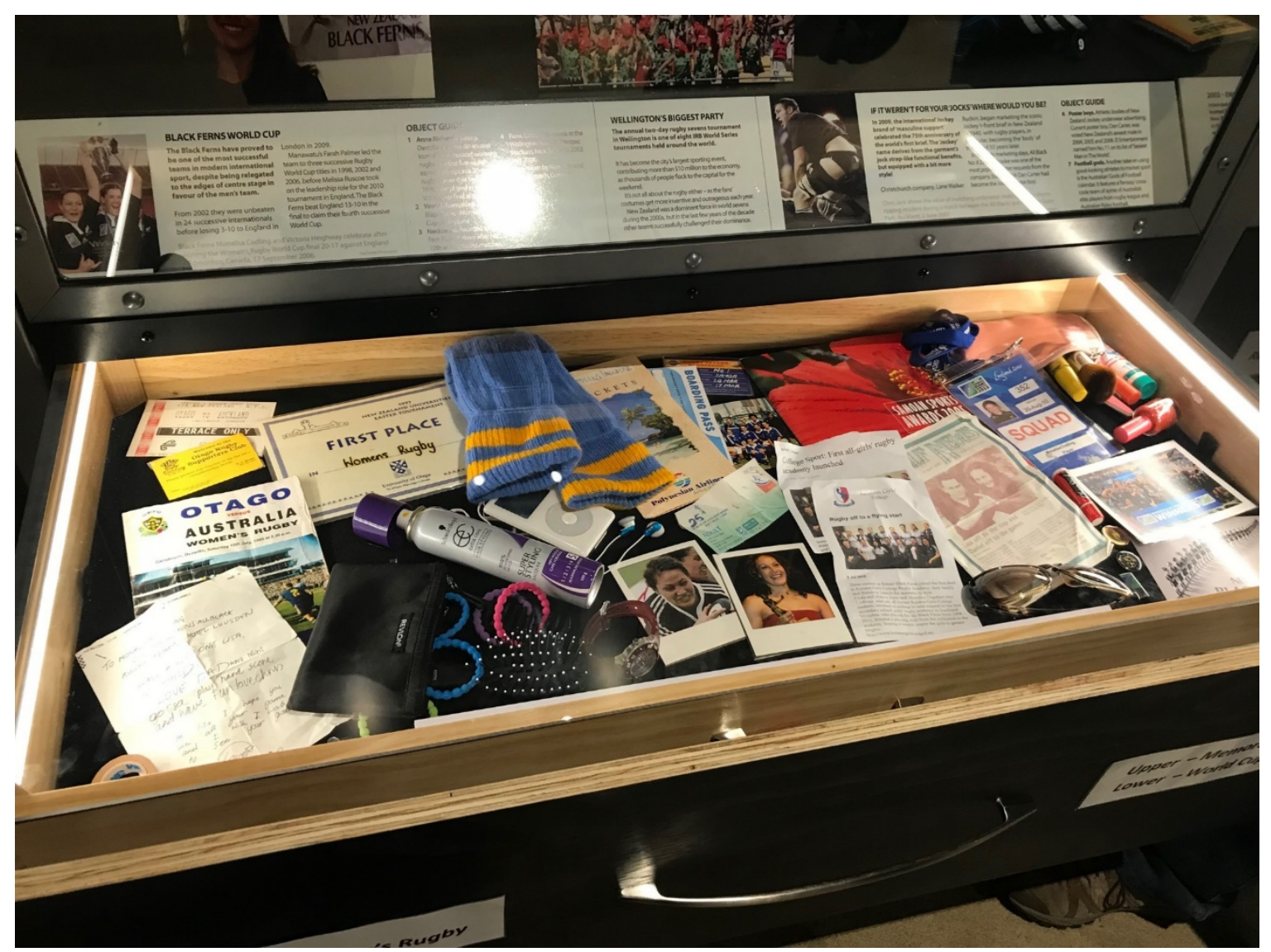

Figure 12. Inside one of the drawers that have been added below some of the cabinets at the Rugby Museum. The intention behind this drawer was to give a glimpse into the personal effects of a woman rugby player. Photograph by the author, 2017.

${ }^{52}$ Anderson, interview with author, 2018.

53 lbid. 


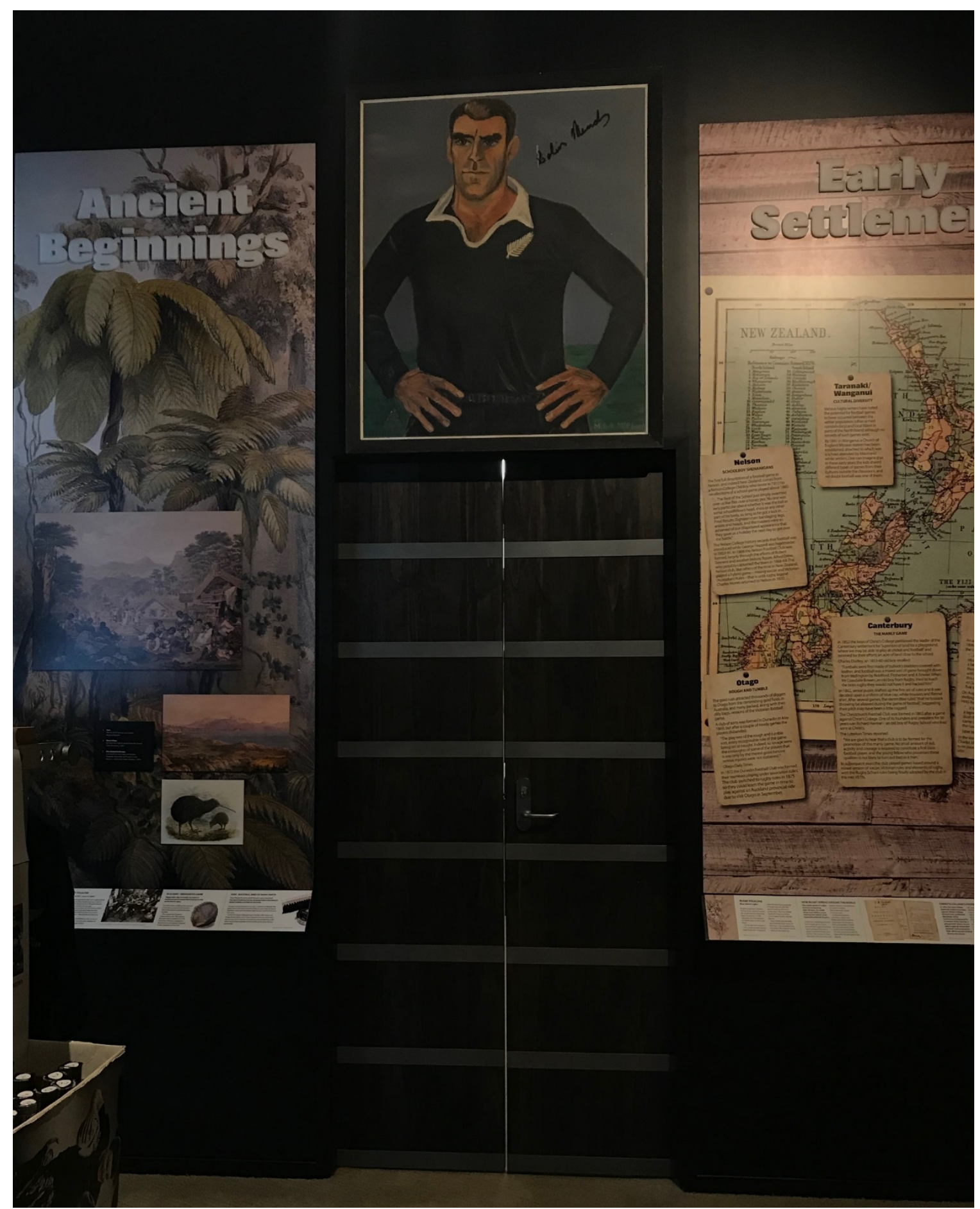

Figure 13. This image shows the first two sections of the rugby relics gallery, "Ancient Beginnings" and "Early Settlement". The portrait of Colin Meads was installed above the door of the director's office in commemoration of his passing in August 2017. Photograph by the author, 2017.

\section{Early years}

Most of the cabinets in the rugby relics gallery relate to a specific decade. At the beginning of the exhibition, there are two informative wall panels, "Ancient beginnings" 
and "Early settlement," and a small glass cabinet, "English roots". 54 "Ancient beginnings" looks at the origins of the game, and of the symbols that have become synonymous with New Zealand rugby - the silver fern, and the kiwi. "Early settlement" has snippets of rugby history in the different regions of New Zealand, including games between Māori and Pākehā in the Taranaki/ Whanganui region, and accounts of Christ's College students petitioning officials for a patch of land to play football and cricket in the early $1850 \mathrm{~s}$ Canterbury. The exhibition considers issues like the emergence of a consistent set of rules, formation of early clubs and the emergence of a rugby staple in New Zealand: beer. "English roots" considers folklore and mythology surrounding the game, from the first time someone decided to pick up and run with a football, to fictionalised accounts of schoolboy rugby in nineteenth-century literature. Objects on display include an inflated pig's bladder, illustrating materials used to fashion early rugby balls, and a variety of old rulebooks.

\section{Rugby by the decade}

For each decade between 1870 and 1990, there is a large glass cabinet packed with rugby related objects with a panel of exhibition text at the bottom relating to that decade. Most of the cabinets are the same size, however, a couple are slightly smaller. Each cabinet contains a wide range of objects, often layered over each other, with an object guide printed with the exhibition text at the bottom. In between some of the cabinets, there are small text panels that provide an overview of the general New Zealand historical context during that time period.

\footnotetext{
${ }^{54}$ New Zealand Rugby Museum, Palmerston North.
} 
1870 s

According to the exhibition, the 1870 s were when rugby "kicked off" in New Zealand. ${ }^{55}$ The section recalls occasions such as the first recorded football game in New Zealand between Nelson Football Club and Nelson College in 1870 and considers the emergence of inter-provincial matches. Examples of objects in the 1870s cabinet include replicas of common use referee flags and photographs of early central North Island rugby teams in the 1890s and 1890s. On the side of this cabinet, a small text panel provides further historical contextual information about 1870s and 1880s New Zealand, accounting for the establishment of large-scale public works projects, assisted immigration, and New Zealand's trade relationship with Britain.

$1880 s$

The 1880s cabinet begins to look at early tours to and from New Zealand, noting that the first rugby tourists arrived in 1882 from New South Wales, and New Zealand's first international tour departed for Australia in 1884. The exhibition also notes that this was the decade where the 'sound' of rugby emerged, when the whistle was first introduced into the game some time in 1883 or 1884 . Objects on display in this cabinet include photographs of the Australian and New Zealand touring teams, and further ephemera relating to the 1884 overseas tour.

${ }^{55}$ New Zealand Rugby Museum, Palmerston North. 


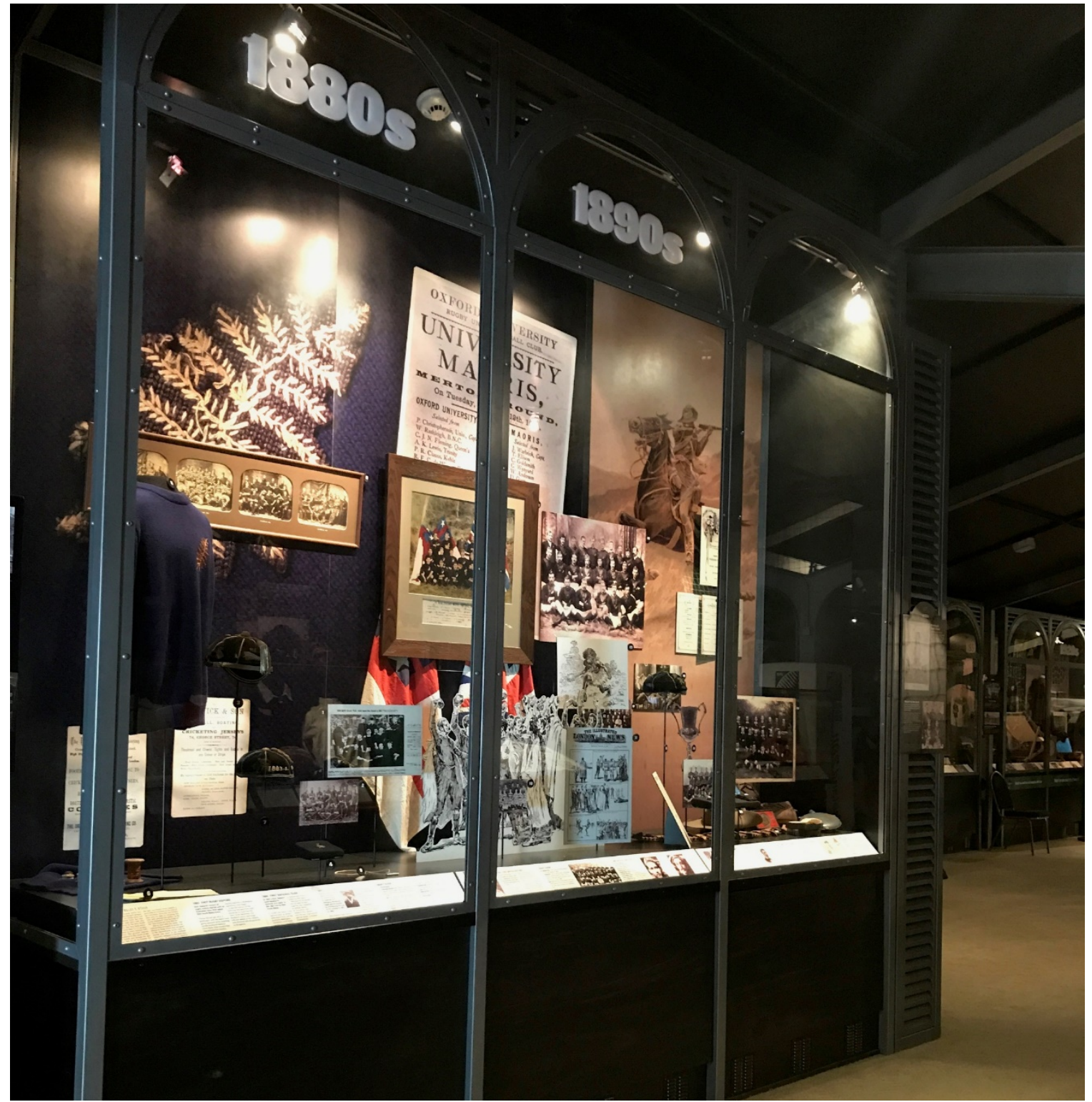

Figure 14. The "1880s" and "1890s" cabinets in the Rugby Museum. Photograph by the author, 2017.

$1890 s$

Rugby highlights of the 1890s, according to the exhibition, include the first British tourists in 1888 , the New Zealand 'Native' tour in $1888-1889$, failed attempts by "lady footballers" in Auckland to tour around New Zealand in 1891, and the establishment of the New Zealand Rugby Football Union (NZRFU).$^{56}$ Objects on display include copies of articles admonishing the "lady footballers," caps and cups relating to tours of the decade,

${ }^{56}$ New Zealand Rugby Museum, Palmerston North. 
and more photographs of local and national teams. On the side of the cabinet a small text panel noting the historical context of the decade, considers New Zealand's relationship with Britain, and the campaign for women's suffrage.

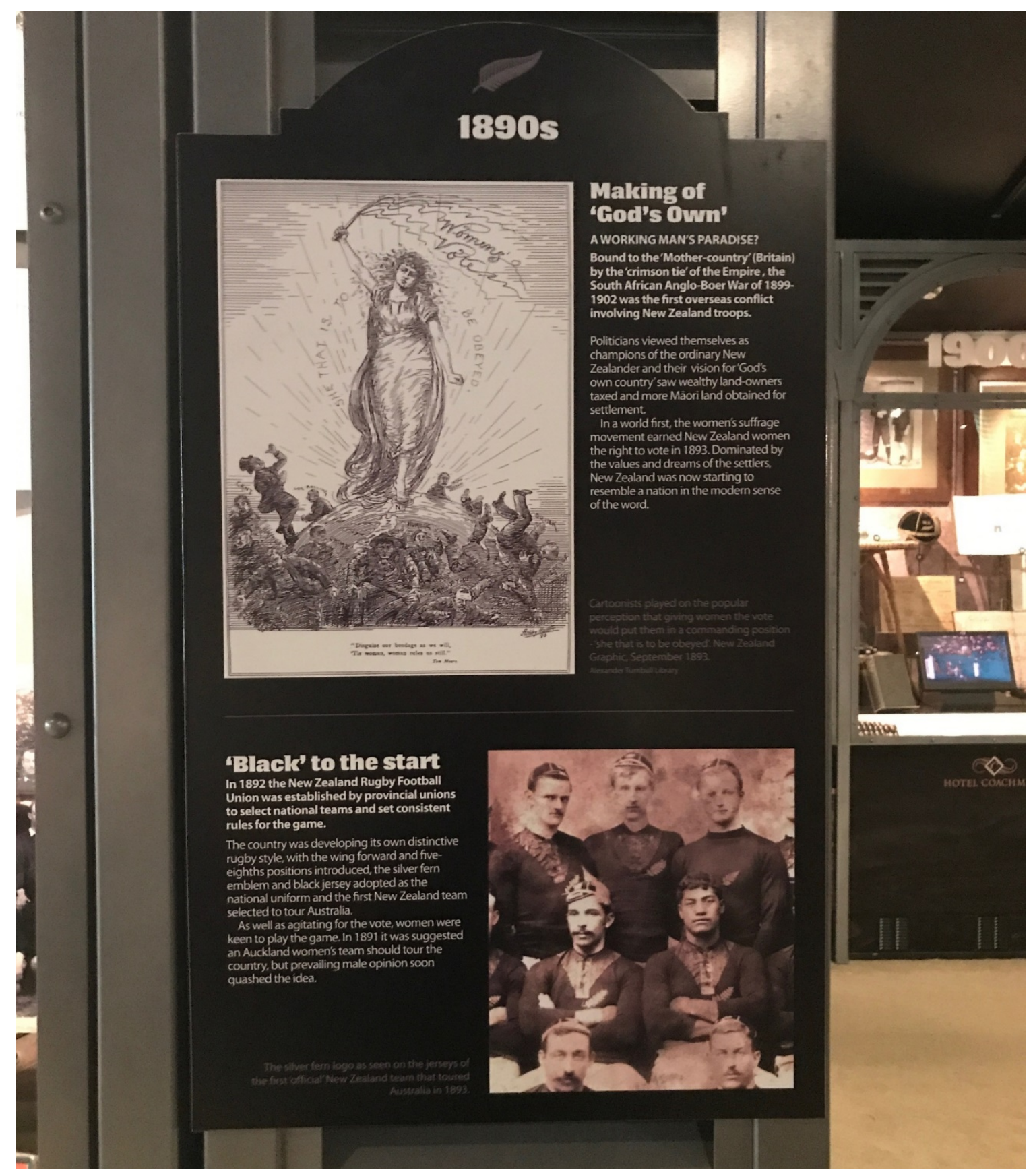

Figure 15. An example of the small panels on the side of the cabinet providing snapshots of New Zealand historical context as it related to the exhibition. Photograph by the author, 2017. 
The 1900s display focusses on the many rugby 'firsts' that occurred throughout the decade including New Zealand's first test match in 1903 and New Zealand's first test match win on home soil in 1904. The exhibition text pays particular attention to the 1905 touring team dubbed the 'Originals'. Objects in the cabinet include tour mementoes kept by 'Originals' team members, souvenirs from the test matches, and photographs of the touring teams. Contextual information on the 1900s and 1910s side panels focusses on New Zealand's new status as a dominion, and the First World War.

$1910 \mathrm{~s}$

The First World War takes pride of place in the 1910s cabinet. The exhibition looks at the games played overseas while players were on duty and pays a tribute to the thirteen All Blacks who died in the War. Featured also in this exhibition is the establishment of the first Māori team in 1910. Objects displayed in the 1910s cabinet include a wide array of objects collected from various tournaments played in 1919. Women players briefly surface, as the exhibition mentions a charity match between soldiers and women on the home front. In the object captions, the exhibition makes its first mention of racial tensions that emerged during New Zealand's new-found rugby relationship with South Africa, as a New Zealand player of English and West Indian descent was barred from playing against South Africa. In addition to the objects, knitted poppies are scattered throughout the display. The poppies, according to a small plaque below the cabinet, were added in the lead up to the centenary of World War One. 
$1920 s$

New Zealand's ongoing rugby relationship with the Springboks dominates the 1920s

cabinet. Beginning with the Springboks first tour of New Zealand in 1921, the exhibition notes that "racial issues surfaced during the tour," and were particularly notable when the team faced the New Zealand Māori team. ${ }^{57}$ The exhibition also highlights the first nonmilitary New Zealand team to tour South Africa in 1928. No 'coloured' players were allowed to tour with the team. The 1920s cabinet also mentions the successful 1924-25 'Invincibles' touring team, dubbed by the exhibition as "heroes". Objects included in this part of the exhibition include mementoes from tours, a gramophone music record performed by All Black George Nepia, and many photographs of various teams throughout the decade.

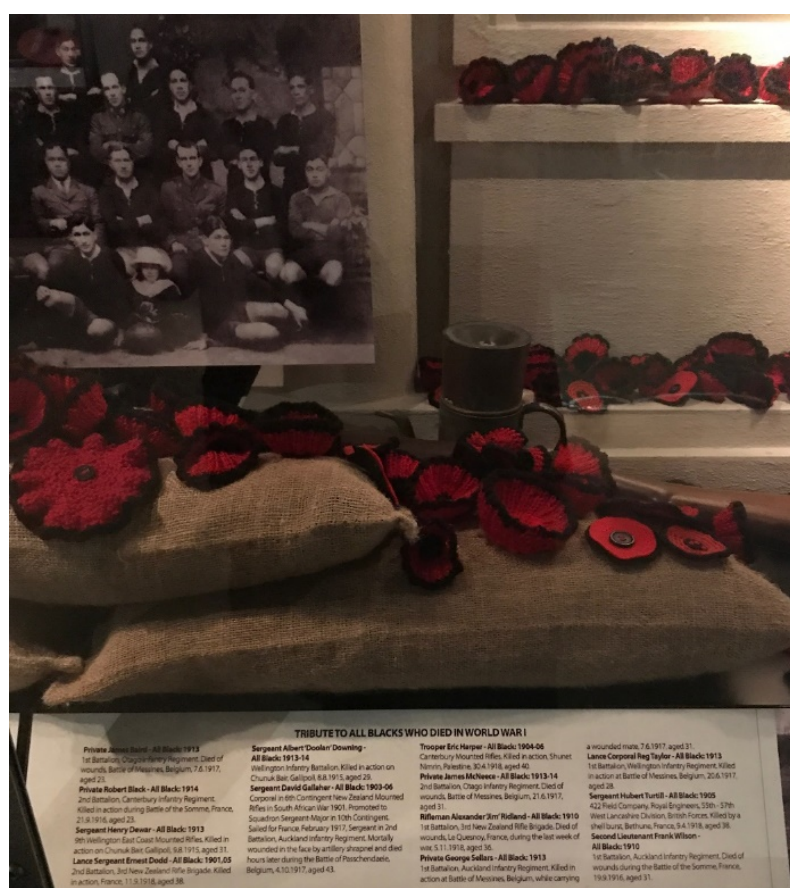

Figure 16. Close up of the knitted poppies added to comemorate the centenary of World War One in the "1910s" cabinet. The black trim around the poppy is a special nod to the rugby players who served. Photography by the author, 2017.

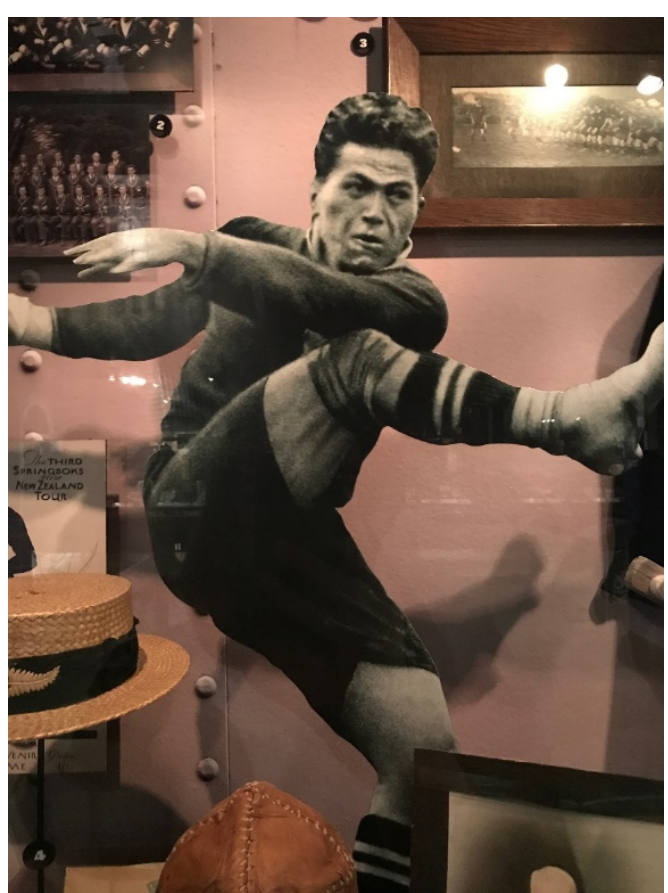

Figure 17. A large cut out of a photograph of rugby great, George Nepia in the "1920s" cabinet. This image is a helpful example of the ways the exhibition team creatively displayed flat, paper based ephemera. Photograph by the author, 2017.

${ }^{57}$ New Zealand Rugby Museum, Palmerston North. 
$1930 s$

Moving on to the 1930s, the exhibition text focusses predominantly on rugby during the Depression. The exhibition discusses the origins of the Bledisloe Cup, and tours that occurred on New Zealand soil throughout the decade. The exhibition discusses the All Blacks tour of Britain in 1935-1936, and claims that is has been "unfairly placed in history as one of the least successful touring sides". ${ }^{58}$ Featured objects in 1930 s cabinet are two All Blacks jerseys, a Japanese student team jersey, and a replica of the Bledisloe Cup.

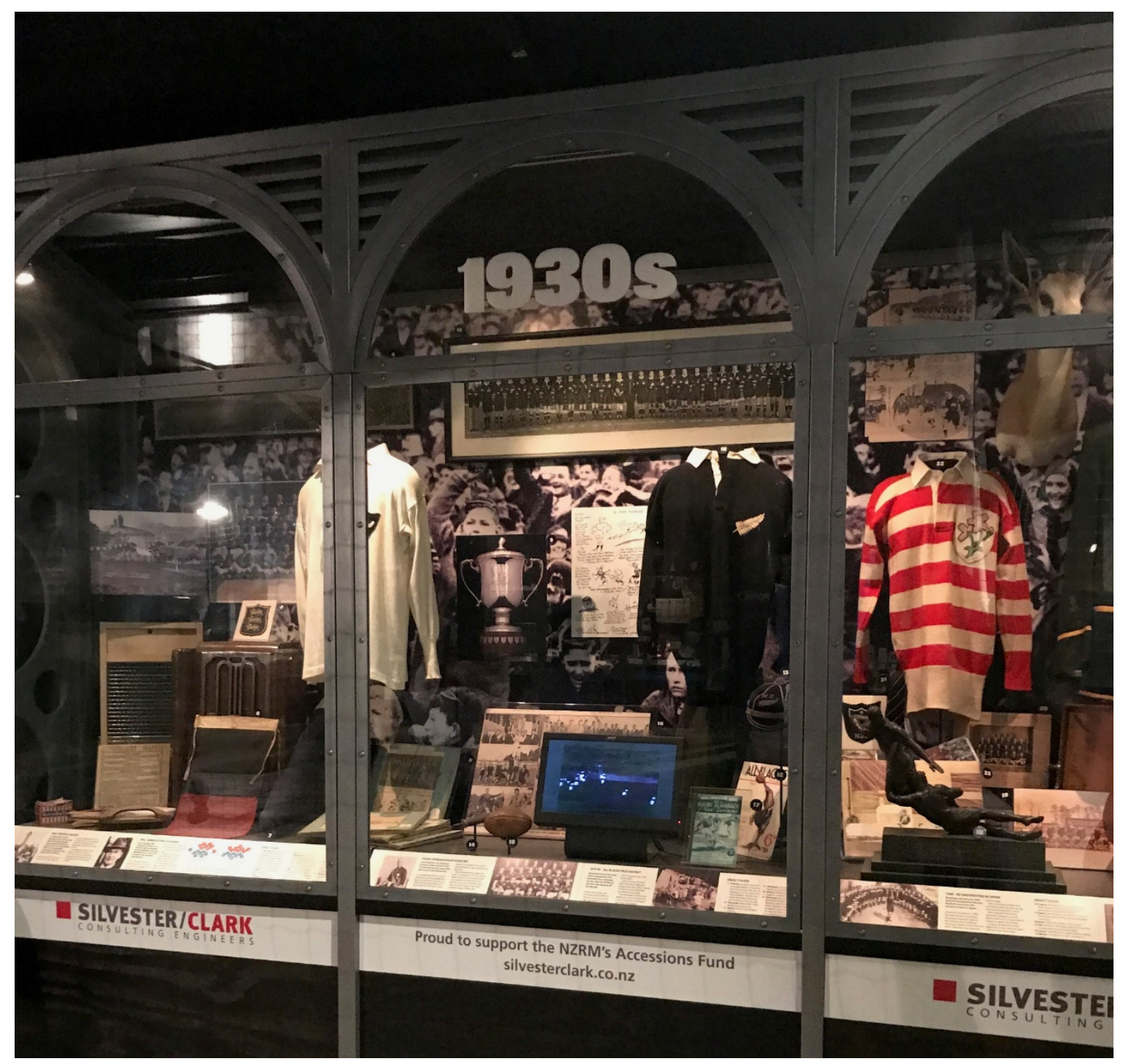

Figure18. Image of the "1930s" cabinet . Photograph by the author, 2017.

${ }^{58}$ New Zealand Rugby Museum, Palmerston North. 
$1940 s$

Similar to the 1910 s cabinet, the 1940 s cabinet is populated predominantly with objects and stories relating to the Second World War. A large section of the exhibition text is dedicated to the All Blacks that died in the War, along with quotes from soldiers reminiscing about rugby during wartime. The Freyberg Cup, a competition between military units established by General Freyberg during the War (it is unclear if this is the original, or a replica) takes pride of place in the 1940 s cabinet and is surrounded by items relating to the War and rugby.

$1950 s$

After the War, the 1950s cabinet focusses predominantly on the tours that took place throughout the decade, including two Lions tours of New Zealand, a New Zealand tour of the United Kingdom, and a visit from the Springboks. Consequently, most of the objects in this cabinet relate to objects collects from the various tours. The exhibition accounts for the rise of rugby fandom, noting that rugby's increasing popularity after the war, often resulted in over filled stadiums. 


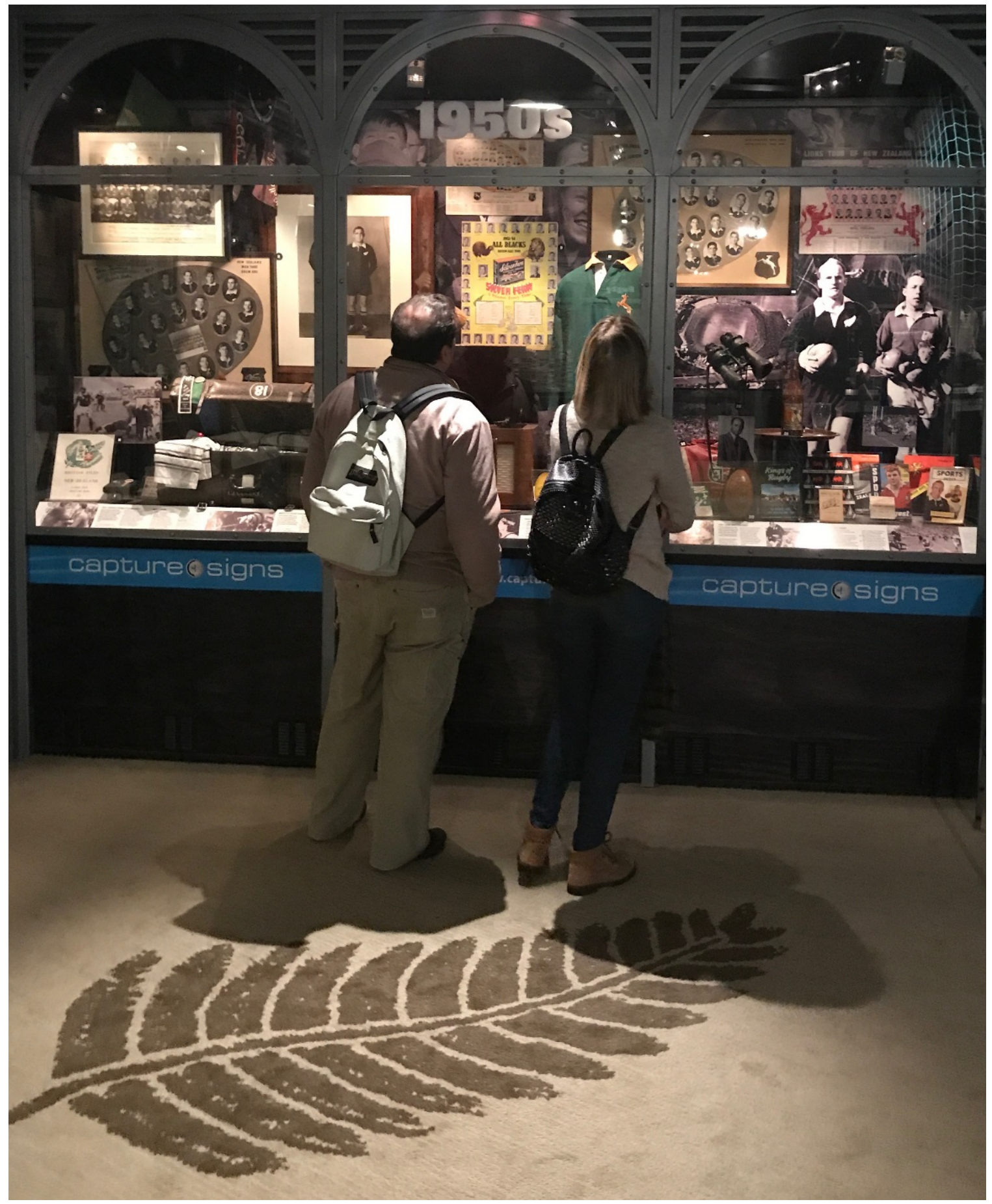

Figure 19. Two visitors looking at the "1950s" cabinet in 2017. Photograph by the author, 2017.

$1960 \mathrm{~s}$

Mounting tensions between New Zealand and South Africa are highlighted in the 1960s cabinet, beginning with New Zealand's controversial tour to South Africa in 1960. The exhibition notes that outrage about the ban on Māori players visiting South Africa began 
to spark protests and led to the cancellation of the 1967 tour. This section also includes a section called "Four Knights of Rugby" profiling four knighted players and their contribution to rugby. ${ }^{59}$ Although tensions with South Africa dominate the exhibition text in this section, objects on display relate to other matches played and events occurring throughout the decade.

$1970 \mathrm{~s}$

The 1970s cabinet highlights a diverse array of events. Although South Africa is mentioned in one part, most of the exhibition text centres on other parts of rugby history during the decade. The display focusses on matches and tours with other countries and teams other than the Springboks. Highlighted here also is the growing popularity of sports media and the establishment of the National Provincial Championship. Objects included in this cabinet match the diverse happenings during this time period, with a wide range of memorabilia and photographs.

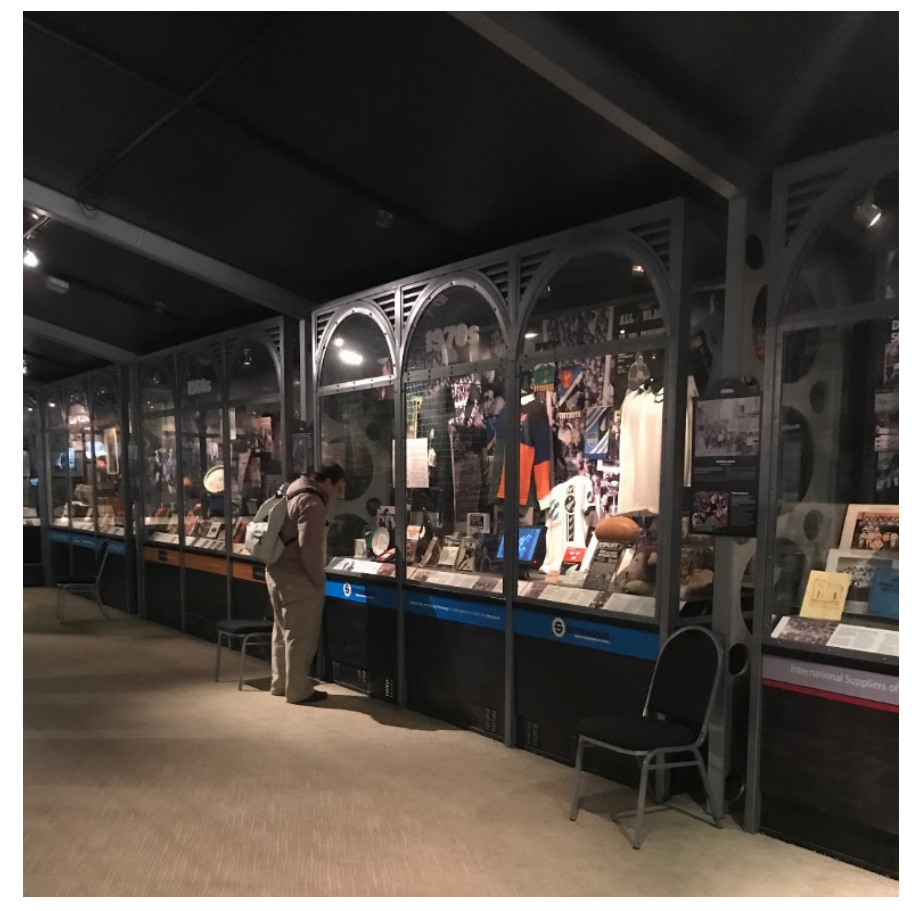

Figure 20. Snapshot of the cabinets on the right hand wall. Photograph by the author, 2017.

${ }^{59}$ New Zealand Rugby Museum, Palmerston North. 
$1980 s$

While the 1970s cabinet paid little attention to mounting tensions with South Africa, the 1980s cabinet centres on the 1981 Springbok Tour and the changing times in New

Zealand. On display are objects including a police baton, protest posters, photographs of protesters clashing with the police, and memorabilia from the tour. The exhibition text also takes note of the first national women's representative game in 1980, and the emergence of the rugby sevens tournament.

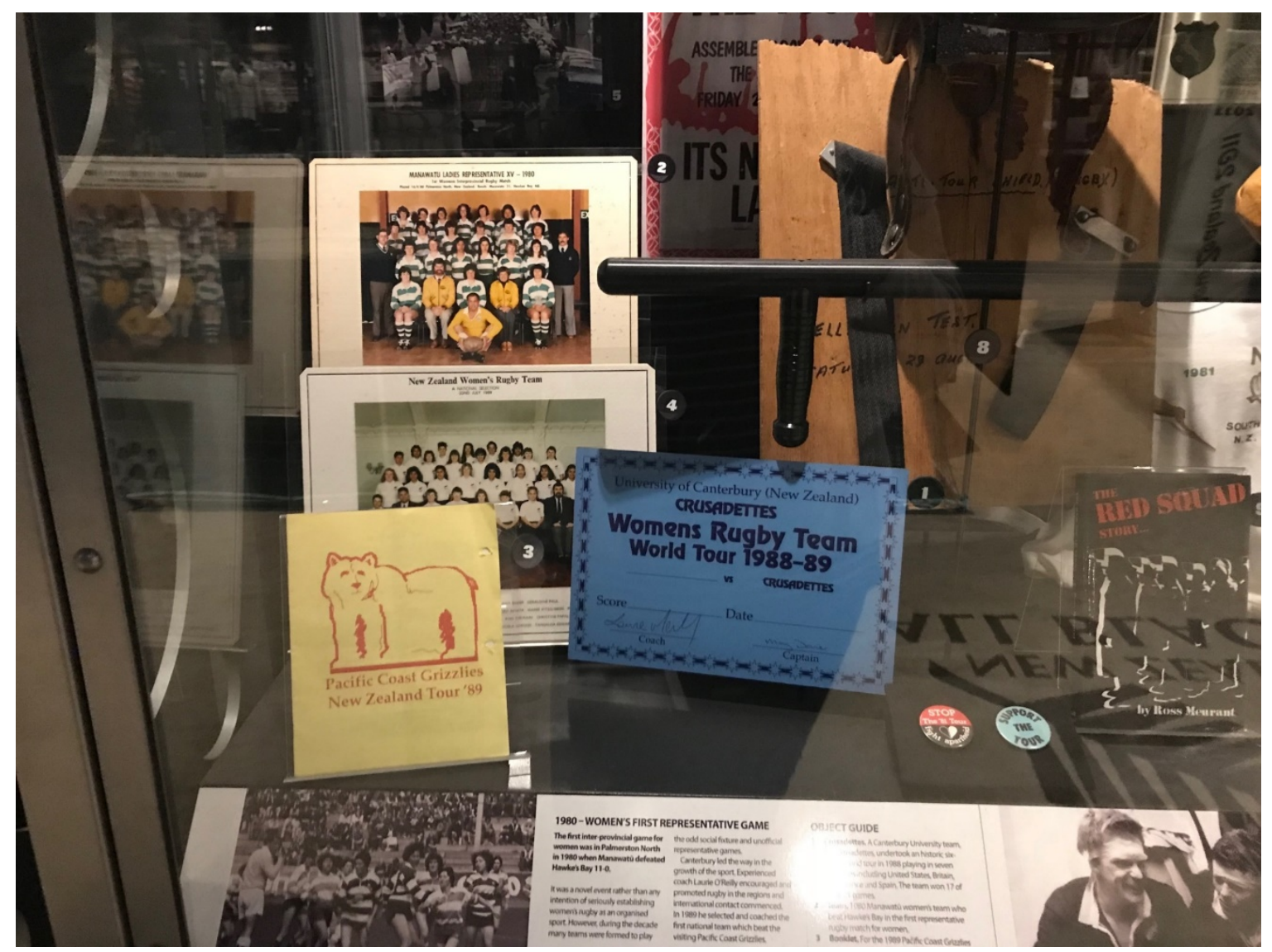

Figure 21. A close up inside the "1980s" cabinet. While women have been mentioned in previous sections, this is the first area where women's rugby is on display. Note the police baton to the right. Photograph by the author, 2017.

$1990 s$

The final three cabinets focus on rugby in the professional era. While the 1990s looks at different tours and matches that happened during the decade, the cabinet also pays 
attention to issues relating to the professionalisation and commercialisation of rugby from 1995. In particular, the exhibition text looks at sponsorship, and considers the way players became a "product" that could be sold "on the open market". ${ }^{60}$ Objects included in this cabinet reflect this, showing branded merchandise such as calendars and posters sold by sponsors.

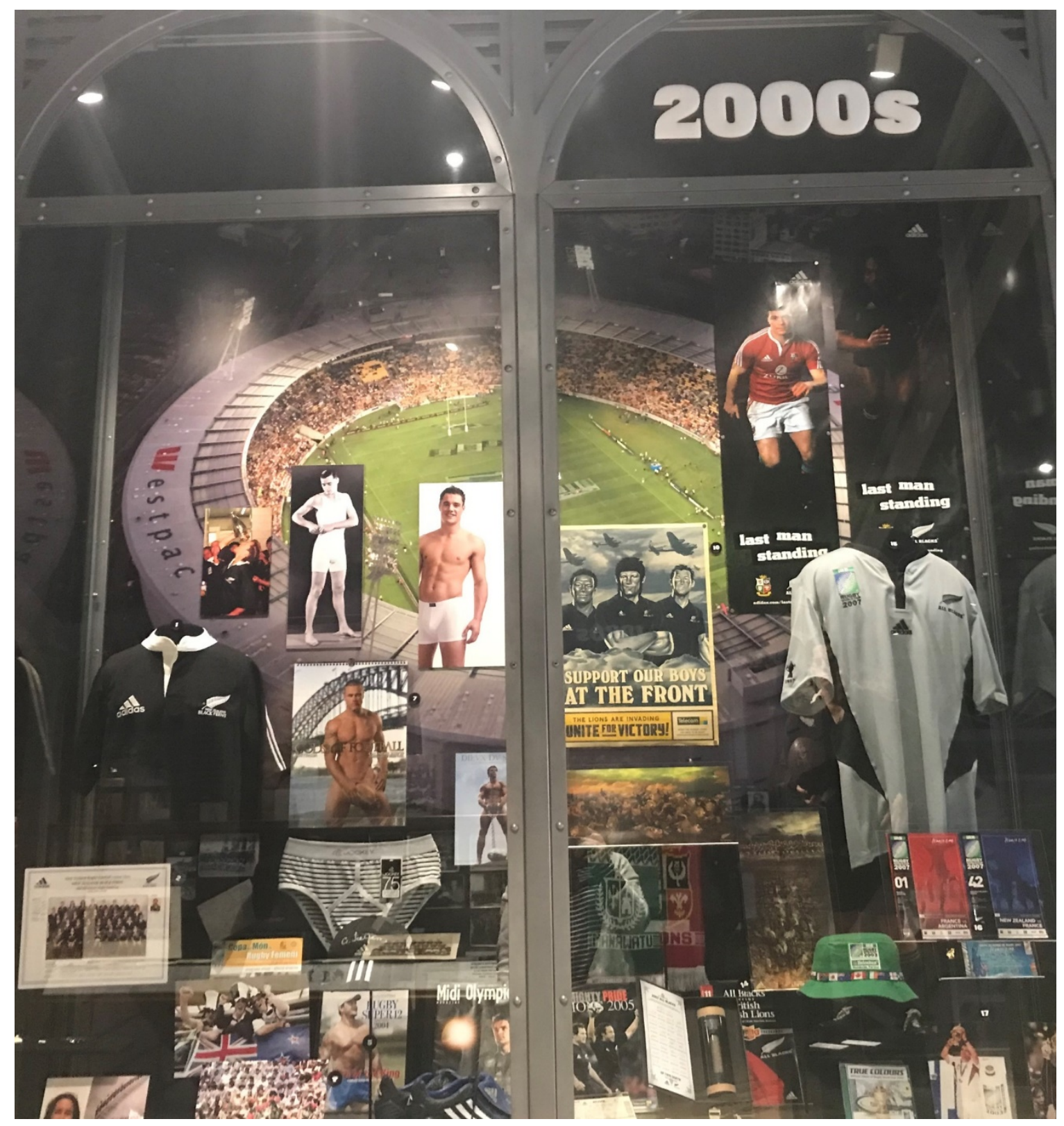

Figure 22. Inside the "2000s" cabinet, featuring corporate sponsors and rugby men modelling. On the far left, next to the men's underwear, is a Black Ferns jersey, and two images of the team commemorating their successive world cup titles in 1998, 2002, 2006 and 2010. Photograph by the author, 2017.

${ }^{60}$ New Zealand Rugby Museum, Palmerston North. 
Continuing on the theme of commercialisation, the 2000s cabinet dedicates considerable space to the underwear brand, Jockey, and their rugby player "poster boys". On the far edge of the cabinet, the women's Black Ferns are also highlighted, and are touted as “one of the most successful teams in modern international sport, despite being relegated to the edges of centre stage in favour of the men's team". ${ }^{61}$ Objects on display in this cabinet include an array of rugby players modelling in their underwear, commercial posters, and team photographs.

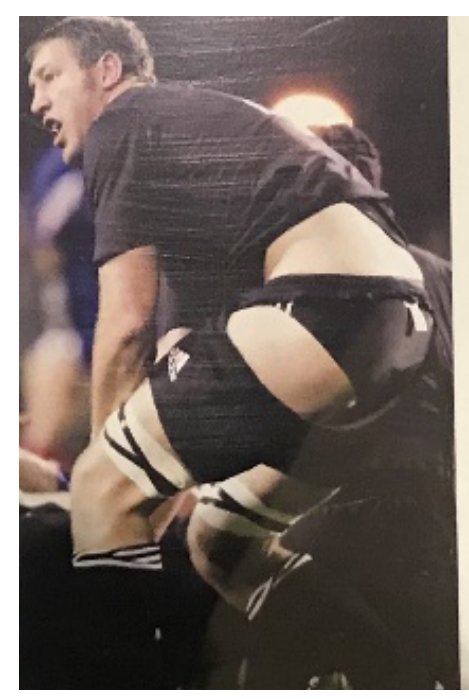

\section{IF IT WEREN'T FOR YOUR'JOCKS'WHERE WOULD YOU BE?}

In 2009, the international Jockey

Rudkin, began marketing the iconic brand of 'masculine support' Jockey Y-front brief in New Zealand celebrated the 75 th anniversary of in 1940, with rugby players, in the world's first brief. The 'Jockey' particular, becoming the 'body' of name derives from the garment's the brand 50 years later. jock strap-like functional benefits, In the early marketing days, All Black but equipped with a bit more No. 8 Zinzan Brooke was one of the style! most popular poster requests from the company, but by 2004 Dan Carter had Christchurch company, Lane Walker become the Jockey'poster boy'.

Chris Jack shows the value of matching underwear, making good a shortsripping incident during a match between the All Blacks and France at Eden Park, Auckland, 2 June 2007.

Figure 23. A snapshot of the exhibition text at the bottom of the cabinet. Photograph by the author, 2017.

\section{$R W C 2011$}

The final cabinet considers the lead up to the 2011 Rugby World Cup, which coincided with the opening of this freshly redeveloped gallery. The cabinet looks at issues like players and their use of social media, uniforms, e-commerce, and the televising of "New

${ }^{61}$ New Zealand Rugby Museum, Palmerston North. 
Zealand's largest sporting event". ${ }^{62}$ Objects on display in this cabinet include branded merchandise, and ephemera relating to the World Cup and games played in Palmerston North.

Summary

The New Zealand Rugby Museum opened its doors in 1977, with a wide range of collection items relating to New Zealand and international rugby. The museum's most recent iteration opened in 2011, just in time for that year's Rugby World Cup hosted by New Zealand. The museum began as an amateur venture, founded by rugby enthusiasts when New Zealand Rugby declined John Sinclair's offer to use his personal collection to start a museum. Earlier iterations of the museum have been small and relied on volunteer labour. By hiring experienced museum contractors to help with the 2011 redevelopment, the museum was able to build a more modern and professional looking museum. Despite appearances, the museum continues to rely on the help of volunteers, with only one paid full-time employee - the director. In face of a changing landscape, where diversity and inclusion has become a hot button issue in both museums and rugby, the Rugby Museum acknowledges that further work needs to be done to fill representation gaps and engage with more communities. Finances and capacity are a significant barrier for further modernisation, however, with the addition of drawers under cabinets, and a new cabinet for the 2010 - 2020 decade, and plans of "going national", the museum has a chance to become more inclusive of stories and peoples missing from the current exhibition. ${ }^{63}$

\footnotetext{
62 Berg, interview with author, 2018.

${ }^{63}$ In particular, Pacific communities and women.
} 
Te Manawa played on the idea that having the New Zealand Rugby Museum and The Topp Twins exhibition on the same floor was an odd pairing with their "rugby and lesbians" signage in the museum elevators. This chapter shows that there are striking differences between the two exhibitions. According to Te Manawa's 2016 - 2017 annual report, the museum has around forty-five employees. In comparison, the Rugby Museum has just two. Te Manawa is a council controlled organisation, receiving the bulk of its funding from the PNCC. The bulk of the Rugby Museum's funding comes from ticket sales and relies on a substantially smaller operating budget. Despite having a small budget, the exhibition itself at the Rugby Museum cost over one million dollars to design and install and was the result of years of planning. Comparatively, The Topp Twins, was created in less than a year, with a modest budget. ${ }^{64}$ The Topp Twins exhibition is also a temporary exhibition, designed for touring around the country, whereas most of the displays at the Rugby Museum are permanent and have remained relatively unchanged since 2011. A striking difference between the Rugby Museum and The Topp Twins exhibition is design and aesthetic. The Rugby Museum, described by director Stephen Berg, is slightly old fashioned and "Victorian". The cabinets are densely populated, and the text, vast. Where the Rugby Museum aimed for a "Victorian" 'feel', The Topp Twins was designed to make visitors feel like they were at home in their "lounge". Along with having far fewer displays, and significantly less text, The Topp Twins was divided by theme, where the Rugby Museum was displayed chronologically.

There are many more differences between The Topp Twins exhibition and the Rugby Museum. There are, however, a few significant similarities. Most obviously, is their

\footnotetext{
${ }^{64}$ I do not have the exact figures, however, considering the income and expenditure reported in the museum's 2017 - 2018 Annual Report I am certain The Topp Twins exhibition cost significantly less than the Rugby Museum redevelopment.
} 
shared time, space and location. Both The Topp Twins and the Rugby Museum were located on the same floor, of the same building, in the same city, and, for some months, during the same time. The spaces that the two occupied were also of a relatively similar size. Aside from physical similarities, The Topp Twins and the Rugby Museum have a fair few themes in common. Both exhibitions have subject matter that is popular, and touch on elements of society that many people enjoy - entertainment and celebrity. In this way, the two exhibitions are also promotional, and commercial. While the Twins and some rugby players may be touted as 'humble kiwis', both rugby, and the Twins are reliant on fans buying items like tickets and merchandise. Most importantly, as far as this thesis is concerned, both the Rugby Museum and The Topp Twins have at the core of their narrative, a sense of New Zealand culture, history and identity. Both, in wildly different ways, display elements of New Zealand social history. Similarly, the two also claim to have an intimate relationship with New Zealand and New Zealanders. Between The Topp Twins exhibition's tagline of “an exhibition for New Zealand” and the Rugby Museum's claim of "the sport that shaped a nation". The two exhibitions' relationship with, and display of, 'New Zealand', is at the very core of the discussion in the following chapter. 


\section{Chapter Four: Reading national identity and gender}

New Zealand national identity is a discursive construction, ${ }^{1}$ and as such, it is malleable, subject to change over time, critique, and means very different things to different people. While New Zealand national identity is discursive, dominant constructions have real and enduring consequences. ${ }^{2}$ This is particularly important in considering that New Zealand national identity is gendered. ${ }^{3}$ While critique of Keith Sinclair's A Destiny Apart may have rendered the text a tenuous source on New Zealand national identity, it remains a valuable example of the invention and repetition of pervasive national mythologies. ${ }^{4}$ Sinclair contends that it was the masculine domain of the sports and battle fields where events inspiring the emergence of a New Zealand national identity occurred. ${ }^{5}$ In the preface to the first edition of $A$ Man's Country? (which was later removed from the second edition), Jock Phillips notes that he found it difficult to think of examples of women who are held to the same esteem as national heroes such as Edmund Hillary, Michael Joseph Savage, "and those sacred groups, the All Blacks and the New Zealand Division". ${ }^{6}$ While historians have noted that Sinclair and Phillips' theses were themselves acts of "invention," the idea that New Zealand national identity has an intimate relationship with men and masculinity continues to have some purchase. It is with this in

\footnotetext{
${ }^{1}$ Peter Gibbons, 'The Far Side of the Search for New Zealand National Identity', New Zealand Journal of History 37, 1 (2003): 39.

${ }^{2}$ Gibbons, 'The Far Side of the Side of the Search for New Zealand National Identity, 3839.

${ }^{3}$ Caroline Daley, 'The Inention of 1905,' in Tackling Rugby Myths: Rugby and New Zealand Society 1854-2004 (Dunedin: Otago University Press, 2005) 72.

${ }^{4}$ Caroline Daley's critique is particularly useful here: Daley, 'The Ref's Turned a Blind Ear': The Cultural Paradigm and New Zealand's Sport History,' Sporting Traditions 27, 8 (2010), 15-27.

${ }^{5}$ Keith Sinclair, A Destiny Apart: The Search for New Zealand National Identity (Wellington: Allen and Unwin, 1986).

${ }^{6}$ Jock Phillips, A Man's Country: The Image of the Pakeha Male - A History, (Auckland: Penguin, 1987), vii.
} 
mind that this chapter considers the relationship between national identity and gender in the context of The Topp Twins and the New Zealand Rugby Museum.

This chapter will consider ways the two exhibitions grapple with both gender and national identity. The chapter is split into three parts. In the first instance, the chapter will discuss the ways 'New Zealand' is displayed within The Topp Twins, and will then move on to consider how this 'New Zealand' becomes gendered. The second part of this chapter looks at the ways 'New Zealand' is displayed within the Rugby Museum, and considers the relationship this may have, if any, with representation of gender in the museum. The third and final part of this chapter, analyses the findings in the first two sections, and discusses potential meaning the display of gender and national identity in the two exhibitions may present.

\section{"New Zealand is our hometown": Locating 'New Zealand' in The Topp Twins ${ }^{7}$}

'New Zealand' is a central theme within The Topp Twins exhibition. 'New Zealand' and common tropes about what it means to be a New Zealander are central elements of The Topp Twins exhibition. Upon conducting a close reading of the exhibition, four key themes emerge within the exhibition's display of 'New Zealand': The Twins' quintessential 'New Zealandness', humility, fairness, and geography.

Weaved throughout the exhibition is the idea that the Topp Twins embody New Zealand cultural iconography. In a television interview about the touring exhibition opening at the National Library, Jools Topp notes that the exhibition signifies the duo's ascension into

\footnotetext{
${ }^{7}$ The Topp Twins, Te Manawa.
} 
the ranks of "kiwiana" along with things like jandals and Buzzy Bee. ${ }^{8}$ Although this may be considered a brazen claim, the idea that the Twins are quintessentially 'New Zealand' is not unique to The Topp Twins exhibition. This is perhaps best captured by television presenter Mark Sainsbury who, in 2009, exclaimed to his audience: "who would have ever thought our national identity could be summed up so perfectly by yodelling lesbian twins from Huntly?"9 Sainsbury's quizzical tone suggests that there is something peculiar about the Twins, embodying New Zealand identity. ${ }^{10}$

In "Love for New Zealand", the exhibition centred around the Twins' popular television show that ran throughout the 1990s. The show was where the Twins' debuted most of the characters that they are so often remembered for. The introductory panel noted that the Twins' show "revelled in New Zealand traditions", "celebrating all the things that make" the country "home". Wall text claimed that the Twins' characters from the show "got to be part of the New Zealand psyche". This was reiterated in the interactive display that encouraged visitors to "have a go" and dress up and "become" the popular characters. Here, the exhibition text invited visitors to "discover your inner Topp Twin". The idea that visitors are likely to have an "inner Topp Twin" further touts the idea that the Twins, or at least the characters they play, are understood as quintessentially New Zealand, and something New Zealanders may recognise in themselves or others around them.

\footnotetext{
8 Jools Topp, interviewed by Giles Dexter, Newshub, Three, 26 March 2018. https://www.newshub.co.nz/home/entertainment/2018/03/topp-twins-colourfulhistory-goes-on-display.html/ ${ }^{9}$ Mark Sainsbury as cited in Anita Brady, 'Camp Mothers of the Nation? Reading Untouchable Girls,' Women's Studies Journal 24, no. 1 (2010): 4.

${ }^{10}$ Brady, 'Camp Mothers of the Nation?,' 4.
} 
Prevalent within the exhibition are discourses of humility, and the "good old Kiwi do it yourself" (DIY) attitude. The cabinet out in the foyer is a prime example, juxtaposing images of the Twins with international celebrities with images of the Twins set against the backdrop of rural New Zealand. The opening exhibition text noted that the Twins are "Kiwi cultural icons with a can-do attitude". The text panel for the section "Doin' Alright" further presses this notion by using quotes from the Twins from an interview with the curator. The Twins note, "we don't aspire to drive around in limousines. As long as we've got enough money to feed the dogs, pay the rent - that's how we feel that we've made it." In the "On the Road" section, the Twins' 'DIY' methodology is emphasised further with objects that show the makeshift aspects of the Twins' career such as handwritten ticket sales records and designs for album covers. The panel text for this section also makes note that the Twins" "ethos is inclusive", and that they often "share the stage with local musicians and invite everyone to join in". These examples show that the exhibition makes it clear the Twins are good humble Kiwis - just how we like them.

The Topp Twins exhibition did not shy away from the Twins' radical activist past, rather, it is highlighted. The "Activism" section at the centre of the exhibition is a prime example. This section grappled with the Twins' activism in the 1970s and 1980s in some of New Zealand's most polarising moments. The exhibition made little of the involvement in these various protest movements could make the Twins' unpalatable to many New Zealanders. This could be in part due to the distance in time between the 1980s and the contemporary moment that the exhibition was designed within, but equally, so it could also relate to the fact that all of the movements documented in the exhibition could be considered 'successful': Bastion Point, Homosexual Law Reform, anti-nuclear campaigns, and against apartheid during the Springbok Tour. Other protest movements, 
such as women's liberation were not mentioned in the Activism section. While it is unclear why, it could be central campaigns fought for during women's liberation such as abortion and pay equity have not been quite so successful.

Throughout the "activism" exhibition linked the Twins" desire to make "a stand for what's right," with their uniquely 'New Zealand' upbringing. In the opening panel text for the section "Who are the Topp Twins?" it is noted that Twins "credit their upbringing" on the farm "with instilling their values of fairness, common-sense and justice". In the "Activism" panel text, the exhibition noted that "the value of 'getting off your arse and being counted' is central to their hands-on politics". The idea that the Twins' upbringing on the farm is responsible for their commitment to "fairness" and “common-sense" and their 'get off your arse' could be seen as attributing New Zealand values itself with the Twins' 'radical' past. If the Twins were simply fighting for everyone to have a 'fair go', was it really that radical? The idea that the Twins' rural upbringing has something to do with their sense of social justice is particularly interesting here, considering the ways rural New Zealand is often linked with conservatism. Here, in the exhibition and the Twins seem to be reclaiming rural New Zealand as a space of inclusion, and radical social values.

Underlying the idea that the Twins are fundamentally what New Zealand is all about Kiwiana, humility, DIY, fairness and so on, is a sense of New Zealand as a place as well as a set of values. Throughout the entire exhibition, imagery, text and design evoke an idyllic rural New Zealand. Images of the Twins out in the country were littered throughout the entire exhibition, attracting captions such as "on the farm", "animals have always been our friends", and "still country girls at heart". The idea that the Twins' 
remain part of the "country" was further reinforced in the "Who are the Topp Twins?" panel text, which noted that the Twins "still live in the countryside, surrounded by dogs and their beloved horses". This is also evident in the "On the Road" section that noted the Twins' 1989 tour around New Zealand in a caravan pulled by an old tractor was a return "to their rural roots". It appears important that the exhibition stressed that the Twins were, and remain, "country girls".

The idea that New Zealand is small, and casual in nature ran through the entire exhibition. The opening exhibition text noted that the Twins have "become synonymous with small town, rural New Zealand". In the "Love for New Zealand" section, the opening line of the panel text, quoting the Twins, noted "New Zealand is our hometown". In reference to the Twins' 1989 tour, the exhibition notes that it was an opportunity to "take it slow, relax and have time to connect with people along the way". The New Zealand on display in The Topp Twins is small, connected and casual. It is the sort of place where everyone knows everyone, and where people can 'relax' and 'connect' with the land and people. Some elements of the exhibition crossed boundaries between the urban and rural. In the earlier section "Who are the Topp Twins?" the exhibition noted that while making a name for themselves busking in central Auckland, the Twins' decided 'the big smoke wasn't quite their style," opting instead to live in a "wooden shack" out in the West of Auckland "with their three dogs and pet pig". In the "On the Road" section, the exhibition noted that the Twins' are comfortable "playing large concert venues like the Powerstation in Auckland, as well as community halls like Puhoi". The exhibition also documented in the section “Being Out, Being Ourselves”, Lynda Topp's bid for Auckland City mayor in character as Camp Mother and showed clips from the 1997 Hero Parade on Auckland's Karangahape Road. While the exhibition evokes a sense of place in the rural, it also 
shows the Twins' ability to transcend urban and rural divides. The Twins' may feel comfortable at the Powerstation or at Puhoi, but they are "still country girls at heart".

These tropes of rural New Zealand, humility, the do it yourself mentality, Kiwiana, and fairness underwrite many ideas about New Zealand national identity. Looking back at scholarship on heritage discourse, these tropes could also be considered a part of New Zealand's heritage discourse. By promoting the Twins as being part of these tropes about New Zealand, the exhibition is not only positioning the Twins as quintessentially New Zealand, but also further perpetuating the idea that these tropes are important parts of New Zealand identity. Discourse about New Zealand often engages in some level of rhetoric that claims there is something special or unique about the country and its peoples. In March 2018, during the opening of The Topp Twins at the National Library, Lynda Topp noted that "we are an incredible, tolerant, wise, amazing people who live in this country", and that New Zealand is "the most incredible place in the world". ${ }^{11} \mathrm{New}$ Zealand may well be an "incredible place" filled with "amazing people", but as Miles Fairburn has argued, perhaps the most unique part about New Zealand is the "abnormal degree to which its people have borrowed from other cultures". ${ }^{12}$ Even the notion of exceptionalism is not particularly exceptional to New Zealand.

In his influential, A Man's Country? The Image of the Pakeha Male, Jock Phillips argues that the "male stereotype... has become identified with the process of national definition" in New Zealand. ${ }^{13}$ Looking at tropes like the Speight's Man, A Good Keen Man, the

\footnotetext{
${ }^{11}$ Lynda Topp, exhibition opening speech, 26 March 2018.

12 Miles Fairburn, 'Is there a Good Case for New Zealand Exceptionalism?,' Thesis Eleven 92 (2008): 45.

${ }^{13}$ Jock Phillips, A Man's Country? The Image of the Pakeha Male. A History, $2^{\text {nd }}$ ed. (Auckland: Penguin, 1997), vii.
} 
'kiwi bloke', the 'she'll be right' mentality, the heroic rugby player, and so on, it is not difficult to notice that many popular elements of New Zealand national identity are gendered. Elements of 'New Zealand' in The Topp Twins are similarly gendered.

New Zealand, gender, and The Topp Twins

The Topp Twins is a visibly queer exhibition. This is in part due to Siân Torrington's "queer curation" of the exhibition, but also due to the visible queerness of the Twins themselves. This is perhaps best represented through an anecdote from a recent interview with Anika Moa. Here the Twins recount their time as radical lesbian separatists, turning up to a town hall meeting with then Prime Minister, Robert Muldoon to protest. "We started shouting him down and he just looked up at us," Lynda Topp notes, "he just leaned into the microphone and said, 'the only good thing about that lot up there is that they don't breed"'. Jools Topp chimes in to point out that "even from afar, he knew we were lesbians". To which Moa comedically responds, "well... look at you". ${ }^{14}$ The fact that it is possible to read the Twins' queerness from their appearance is an important point to consider, particularly in relation to the imagery included in the exhibition. The Twins' gender performance as masculine of centre (butch) women is tied up in their lesbian identity. ${ }^{15}$ To look at gender and New Zealand national identity within the context of The Topp Twins means it is necessary to look at both sexuality and gender.

Siân Torrington notes that she was incredibly conscious of her responsibility as a queer curator telling a queer story while working on The Topp Twins. ${ }^{16}$ In particular, Torrington

\footnotetext{
14 'The Topp Twins,' Anika Moa Unleashed, TVNZ, 20 June 2018.

${ }^{15}$ I do not know how they would describe their own gender performance, so it should be noted that I am applying these terms without consultation.

${ }^{16}$ Torrington, interview with author, 2018.
} 
notes that she was very deliberate in ensuring that the exhibition remained true to the Twins" "butchness". In explaining the effect this had on the overall exhibition, Torrington recalls two instances during the planning stages. When the exhibition team got to the "Being Out, Being Ourselves" section, covering the Twins' position as 'out' public figures, Torrington notes that there was a suggestion from someone to hang a glitter ball from the ceiling. While this suggestion was likely made in earnest, Torrington found herself having to explain to the exhibition team why "glittery" décor was not appropriate. Although a glitter ball may be appropriate for an exhibition about other people in the queer community, it was important to Torrington that the Twins be displayed in a way that mirrored their reality as butch, rural women. Torrington notes that she felt as though there was an attempt to "tone down" the Twins" "butchness", citing another example where someone tried to "soften" an image of the Twins looking masculine wearing leather jackets by placing it over a gingham background. Ultimately Torrington was able to sway her colleagues into including the images as is. This is particularly crucial, Torrington argues, in light of the fact that "we don't see butches very much". In Torrington's eyes, something as simple as "how we position images, what background we put them on matters. Everything matters". ${ }^{17}$

17 Torrington, interview with author, 2018. 


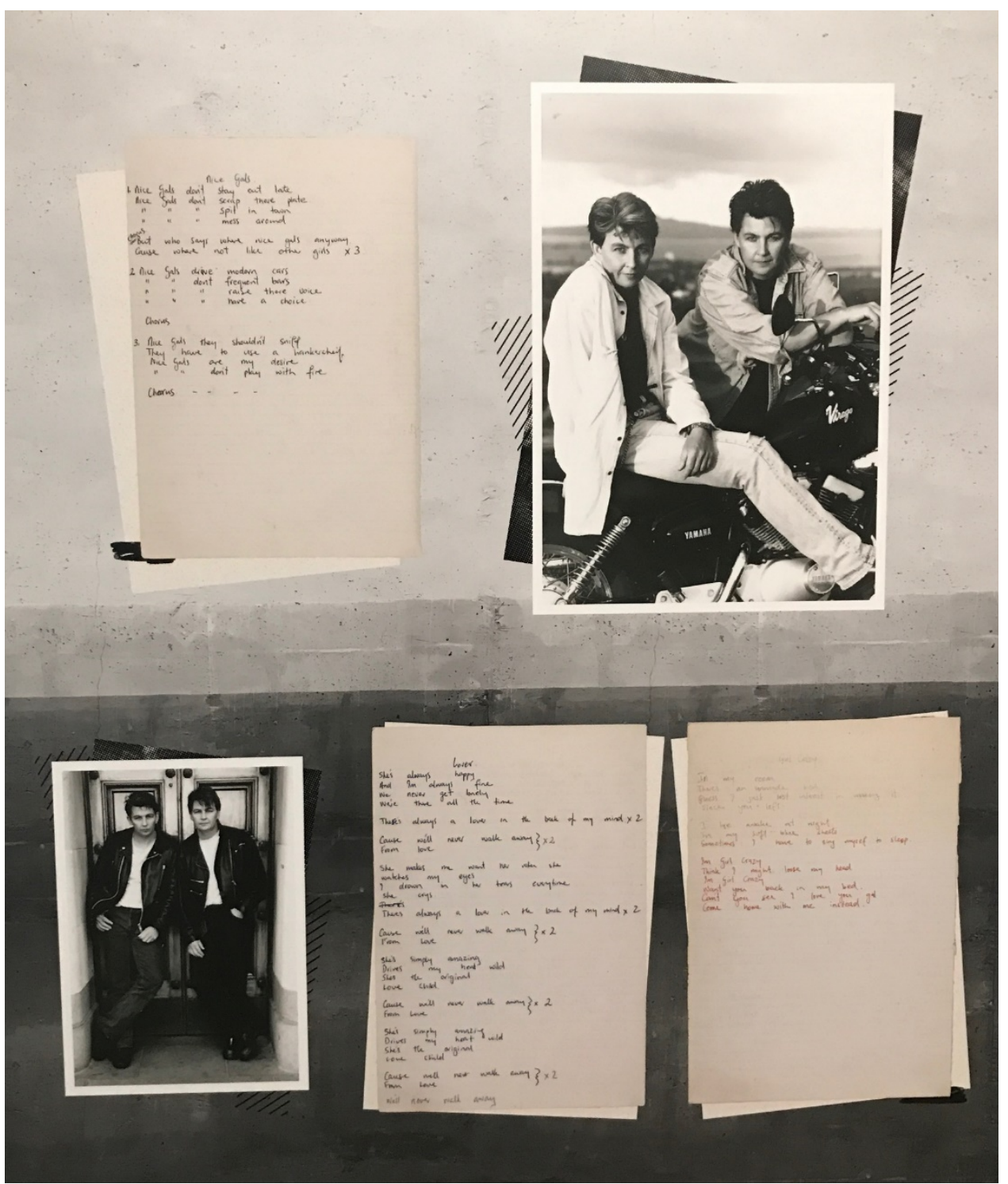

Figure 24. An example of imagery

Torrington was encouraged to "tone down". Photograph by the author, 2017.

In his influential Female Masculinity, Jack Halberstam considers the performance of masculinity by people with "female bodies". ${ }^{18}$ He argues that in considering female masculinity, it is possible to locate the ways masculinity is constructed. ${ }^{19}$ Female masculinity in his view, is often vilified by both women and men. ${ }^{20}$ In comparison, he argues that male femininity "fulfils a kind of ritual function in homosocial cultures". ${ }^{21}$ The Twins are not only performing female masculinity, but they are also performing a

\footnotetext{
${ }^{18}$ Jack Halberstam, Female Masculinity (Durham: Duke University Press, 1998).

${ }^{19}$ Halberstam, Female Masculinity, 3-4.

${ }^{20}$ Halberstam, Female Masculinity, 21.

${ }^{21}$ Halberstam, Female Masculinity, 23.
} 
form of rural femininity. The way that the Twins' gender performance is bound up in ideas about New Zealand rural life, makes it more difficult to apply Halberstam's theories. Halberstam notes himself, that rural women, because of their engagement with more physical, outdoor work, "may be considered masculine by urban standards" and yet still fall within gender norms. ${ }^{22}$ In a 2015 article on the Topp Twins and 'camp', Matthew Bannister shows that while Halberstam's work is an important entry point into understanding 'female' masculinity, it does not necessarily stand up to scrutiny in a New Zealand context, particularly where the Topp Twins are concerned. ${ }^{23}$ Drawing on the earlier work of Nicholas Perry and his 'antipodean camp', Bannister examines the Topp Twins and their career from the perspective of 'camp'. ${ }^{24}$ Bannister argues that while others have sought to consider camp from a New Zealand point of view, queer women (and perhaps, women in general), have been left out of these discussions. ${ }^{25}$ Bannister proposes that while the Twins may have been accepted in New Zealand because they do not directly challenge "the masculine iconography of the Kiwi bloke", it could also be because New Zealand is a space where lesbianism is "relatively accepted". ${ }^{26}$ The assumption underwriting Bannister's thesis is that masculine women are more accepted because New Zealand is a settler colony where women were also required to perform physical labour to tame the land. Written in the Australasian Journal of Popular Culture, Bannister's article neglects to consider the wider historical context that his claim is based upon. However, his argument that New Zealand culture and identity has a part to play in the Twins' acceptability is certainly worth considering.

\footnotetext{
22 Halberstam, Female Masculinity, 34.

${ }^{23}$ Halberstam, Female Masculinity, 96.

${ }^{24}$ Matthew Bannister, '“Bush Camp"? The Topp Twins and Antipodean Camp,' Australasian Journal of Popular Culture 4, no. 1 (2015): 3-14.

${ }^{25}$ Bannister, '“Bush Camp"?,' 12.

${ }^{26} \mathrm{lbid}$.
} 
Anita Brady is similar concerned with the relationship between the Twins and New Zealand identity in her 2010 article 'Camp Mothers of the Nation? Reading Untouchable Girls' ${ }^{27}$ Here Brady considers the Twins' Ken and Ken characters within the matrix of normative New Zealand masculinity. ${ }^{28}$ Two facets of Brady's article are particularly relevant to discussions of gender and national identity within the context of The Topp Twins. Firstly, the idea that in their performance of Ken and Ken, the Twins are citing and repeating (as per Judith Butler) established tropes around New Zealand masculinity, and second, the discussion of whether or not this performance is ultimately subversive. ${ }^{29}$ Brady contends that while the Twins may be seen as rearticulating hegemonic masculinity, their consistent assertion of their identities as lesbians means that Ken and Ken are subverting the discourses they cite: Ken and Ken may well be read as "true blue" kiwi blokes, but the audience is still fully aware, they are women in drag. ${ }^{30}$ While Brady focuses her efforts on Ken and Ken, the idea that the Twins cite tropes about New Zealand culture, and reproduce them in their character work could be pushed further to consider all of the Twins characters, which the exhibition touts as "capturing the New Zealand psyche". ${ }^{31}$ Brady's analysis is particularly insightful, however, her analysis could be pushed further to consider the citations and repetitions of not just gender in New Zealand, but New Zealand culture at large. The Twins' may be inciting 'gender trouble' through their Ken and Ken characters, but it could also be argued that the tropes about New Zealand the Twins cite are not quite so troubled.

\footnotetext{
${ }^{27}$ Anita Brady, 'Camp Mothers of the Nation? Reading Untouchable Girls,' Women's Studies Journal 24, no. 1 (2010): 3-13.

28 Ibid.

29 lbid.

$30 \mathrm{lbid}$.

31 Ibid.
} 

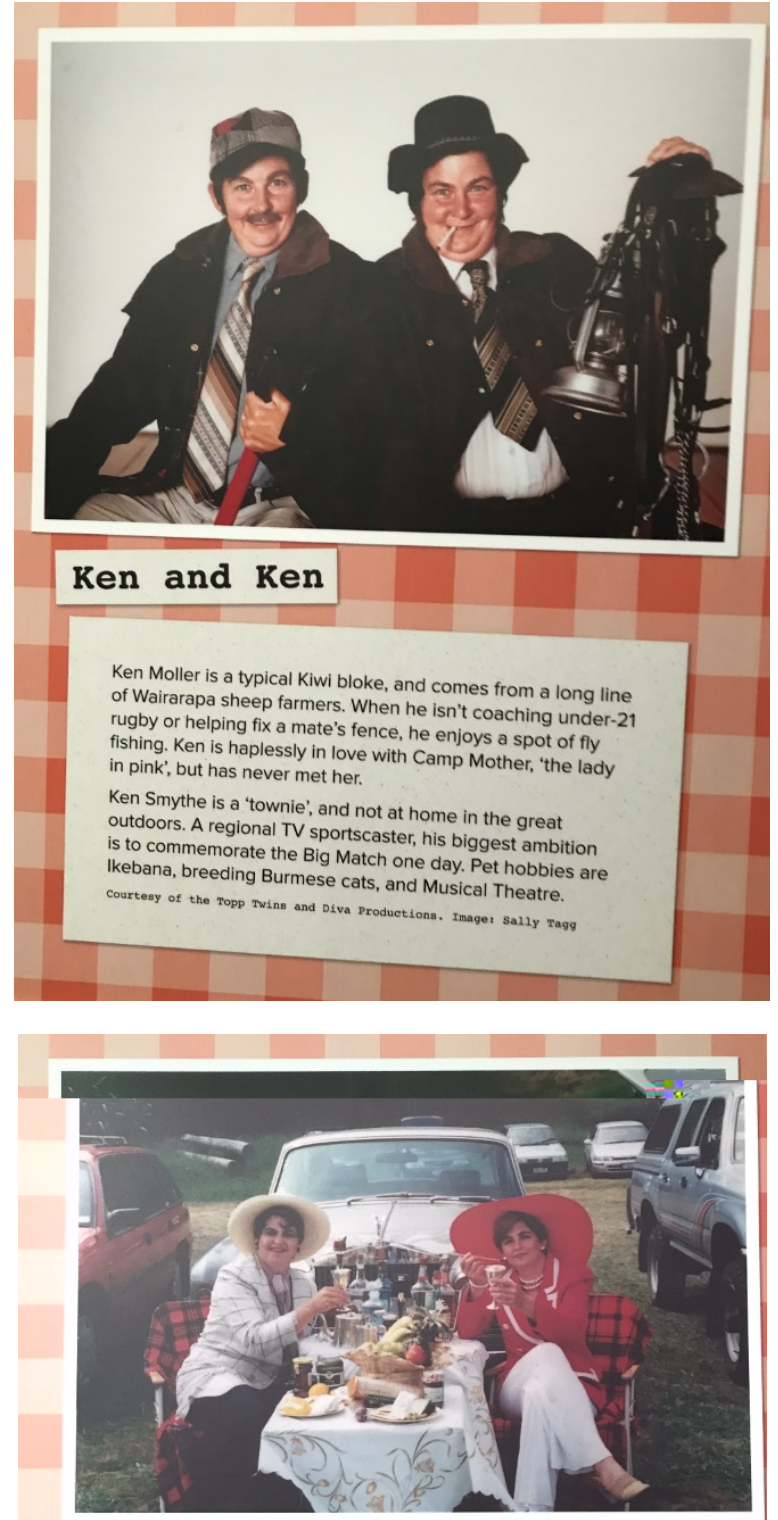

Prue and Dilly

Prue and Dilly Ramsbottom are from an old-money family in Hawke's Bay. They enjoy a drop or two of Chablis, gin or champagne, breed King Charles Spaniels and know all the right champ. Fah fah fah! Always seen at THE social events of the pear, wsully getting out of a Roller in full twin-sets and peats. year, usually getting out of a Roller in full twin-sets and pearls. courtesy of the ropp Twins and Diva Productions. Inages: saliy ragg

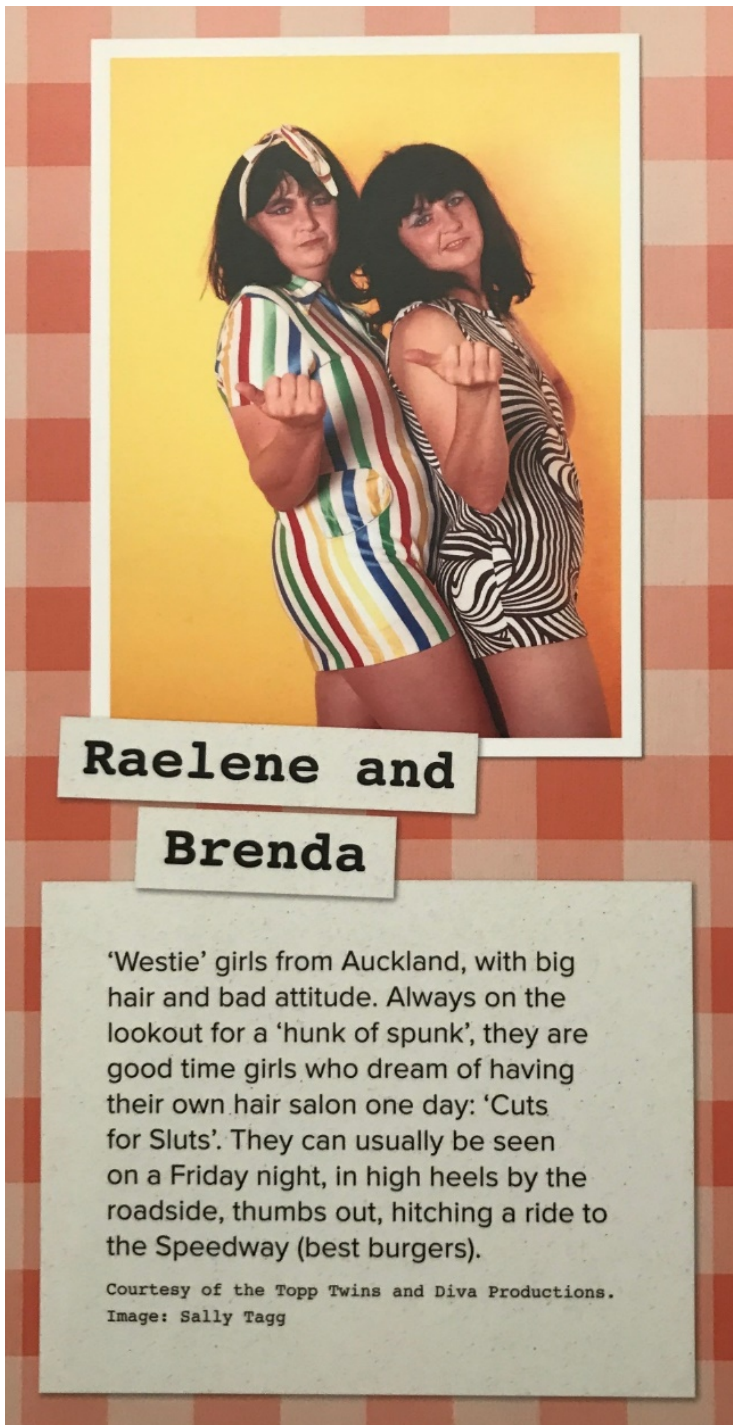

Figure 25. Snapshots of exhibition text introducing the Twins' repertoire of characters. Photographs by the author, 2017. 
Brady's application of Judith Butler's work on gender performativity is particularly helpful in the context of The Topp Twins exhibition. While Brady's analysis focusses predominantly on Ken and Ken, her work opens up many avenues for discussion of all of the Twins characters, and the exhibition at large. For the most part, The Topp Twins focuses on the Twins themselves; however, the five sets of characters also play a key part in the exhibition narrative. In figure 23, the exhibition introduces the characters, using text supplied by the Twin's production company. Taking the characters Raelene and Brenda as an example, two "good time girls" from West Auckland, who dream of catching a man and opening a hair salon called "Cuts for Sluts". In the "Love for New Zealand" panel text, the exhibition notes that the Twins "bring a deep knowledge of our culture, and quirks to life through their characters". Yet somehow where with Ken and Ken, the text draws on the more 'loveable' side of the Kiwi bloke, of loving rugby and "helping fix a mate's fence," the text for Raelene and Brenda's characters suggests that the Twins' 'love for New Zealand' may have its limits. There seems to be, at some level, an air of contempt towards Raelene and Brenda, as they have been reduced down to the more negative stereotypes ascribed to 'bogan' New Zealand women. Here, the bogans are referred to as 'sluts,' but the exhibition makes no reference to the snobbishness of Prue and Dilly or the misogyny of Ken and Ken. 


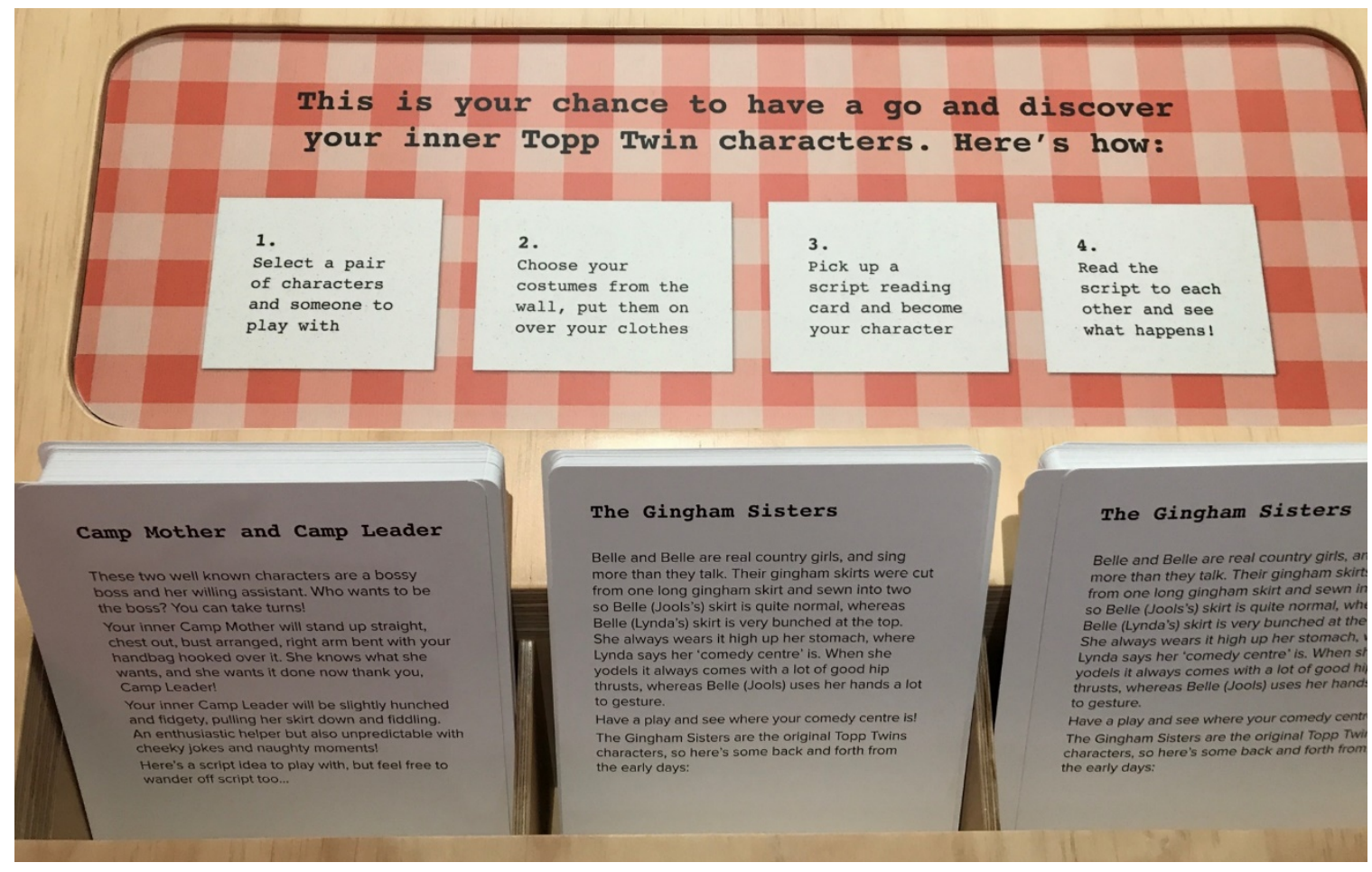

Figure 26. Snapshot of exhibition text inviting visitors to channell their "inner Topp Twin". Photograph by the author, 2017.

Not only are the Twins' characters prevalent throughout the exhibition, they are also part of the visitor participation. As shown in figure 24, visitors are encouraged to don the costume of their character of choice and act out scenes from the Twins' television show. Here the exhibition encourages visitors to discover their "inner Topp Twin”. Considering that the Twins' characters both enact particular tropes about New Zealand and gender, this section becomes a critical point in the exhibition. Not only is the exhibition displaying particular discourses of gender and New Zealand identity, but it is also encouraging visitors to physically transform into them. Another site where visitors are encouraged to perform is in the "activism" section.

Throughout this section, it has become clear that there are some strong moments of gender and national identity. Focus here has been paid on the intersection of those moments. Extending Anita Brady's argument that the Topp Twins are causing 'gender 
trouble' by 'passing' as "true blue" Kiwi blokes, all the while making it clear that they are lesbian women in drag to consider The Topp Twins exhibition is particularly powerful. Brady's thesis is that the Twins 'pass' as Kiwi blokes, because they so expertly cite and in turn, perform, a distinctly recognisable kind of masculinity that is intimately tied with New Zealand identity. The exhibition is visibly queer, and in adding a queer perspective on New Zealand identity, The Topp Twins becomes a vehicle for the Twins' gender trouble. The fact that normative Kiwi masculinity is turned on its head, in an exhibition that is now touring around the country is powerful, and the fact that it originated in the provinces in the Manawatū even more so. However, while the exhibition subverts hegemonic gender discourses (although, not entirely, as seen in the case of Raelene and Brenda), it does little to unsettle hegemonic discourses of New Zealand identity. Rather, the exhibition actively puts those discourses on display.

\section{Putting the New Zealand in the Rugby Museum}

New Zealand is heavily featured throughout the Rugby Museum. Most of the time, New Zealand is mostly mentioned as a backdrop, or setting for games and rugby related events. Throughout the exhibition however, there are small snippets of rugby's relationship with New Zealand national identity and culture.

The first two mentions of New Zealand national identity, and perhaps the clearest examples, come from the first section of the museum "Ancient Beginnings". This section considers the origins of the game, and the origins of New Zealand itself. Here, the exhibition discusses the origins of two symbols that are heavily associated with New Zealand national identity: the kiwi and the silver fern. According to the exhibition text, the silver fern has "become the unofficial symbol of New Zealand's identity". The text 
goes on to note that "the immense sense of pride that New Zealanders now associate with the symbol's placement on the jerseys of their sporting heroes means the fern has an indisputable place in New Zealand culture”. Moving onto the kiwi, the exhibition notes that "as the kiwi began disappearing in the late $19^{\text {th }}$ century, its image started featuring on New Zealand products, banknotes and stamps, and it became the defining national identity under which 'proud kiwis' paraded on the worlds sports grounds and battle fields". In the "1910s" section, the subject of 'Kiwis' comes up again, this time in a section titled "forever etched in our nation's memory". The exhibition notes that "for New Zealand soldiers, fighting alongside other nations sparked a sense of separate identity, and many began to refer to themselves as 'Kiwis"'. This also included, as the exhibition notes, the 'Kiwis' rugby team formed by the New Zealand armed forces while at war.

An interesting way that the museum grapples with rugby and nationalism, is the way it discusses rugby victories and defeats. In the section on the 1905 'Originals' team, the exhibition notes that “the team's historic (and only) defeat on tour... still rankles with New Zealand fans, due to a controversial disallowed try by Bob Deans". Here, it is important that the exhibition notes that the loss was not because the other team was better, but because of a technicality. Caroline Daley notes, that the way historians have talked about the 'Originals' team, often ignores the criticism that the reason they won so many games, was because they played rough and unfair. In a segment in the "1940s" section, the exhibition notes that there was a tour of Britain during the end of the Depression. The exhibition notes that "times were tough and the team faced a difficult record in living up to the high standards set by the 1905 'Originals' and 1924 'Invincibles'”. Here, again, the exhibition, in discussing defeat, notes that external factors were the cause of the loss 
rather than the other team winning. It was not that the All Blacks of the 1935-36 tour were not good enough, but rather that the 1905 and 1924 teams were too good to compare.

Some of the sections that discuss New Zealand have a colonial narrative. In "Early settlement," the exhibition notes that "the noble game of rugby started emigrating from Britain, via naval ships and military unites visiting the realms of an expanding British Empire". The exhibition also notes that organised rugby did not commence until the "latter part of the $19^{\text {th }}$ century when teachers, missionaries and settlers became established". Rugby The "early settlement" section also ponders the ways rugby could have been played between Māori and Pākehā at the time, noting "one can imagine that in these early years the kids shared different types of games from their cultures outside of the classroom and no doubt football was one of them". In the historical side panel next to the "early settlement" section, the exhibition makes not of a time when other sports, like cricket and racing, were more popular in New Zealand. The section "BR: Before Rugby," as if to say after rugby, New Zealand was never the same.

Gendering the Rugby Museum

Gender is not an explicit feature of the New Zealand Rugby Museum. While there are some direct references to masculinity, generally speaking, the museum refers only to gender when it relates to women. Both Anna Reading and Laurajane Smith note that conflating gender with women is a real issue within heritage spaces like museums. ${ }^{32}$ While the subject of the museum is about a sport that has been the domain of New

\footnotetext{
32 Reading, 'Making Feminist Heritage Work,' 400-01; Smith, 'Heritage, Gender and Identity,' 159.
} 
Zealand men since it arrived soon after colonisation, the gendered element of the game is not particularly evident in the museum.

The first mention of women comes fairly early on in the exhibition, in the "1890s" cabinet. The exhibition text refers to "a brave attempt by 'lady footballers' ... to tour New Zealand". The 'attempt' according to the exhibition, was thwarted by "the establishment". The exhibition refers an article in the Auckland Star, calling "girls" participation in football, "essentially unwomanly," and notes "not surprisingly, the Auckland Star received a strongly worded reply from the team's manageress". The use of "not surprisingly" is interesting here, as it places some level of value judgement that it was not a surprise that the manager, a woman, complained. While the intended meaning of this is up for interpretation, the use of the "lady footballers," "girls," and the inference that it was typical that a woman complained, could be seen as slightly paternalistic in tone. Nearby in the 1900s and 1910s historical context panel, women are mentioned again. This time, the exhibition notes, under the heading "Killing fields," that "with many fit young men mown down on the battlefields, rugby was only played back home by those under military age, with a few women making up the numbers!" On a similar note, a couple of images of a women's rugby team is displayed in the 1910s cabinet. This is the first visual depiction of women rugby players. The caption again, alludes to the reduction in men available to play rugby, with women filling the gaps. The caption is titled "battle of the sexes" and notes “these rate images show a women's team (in hobble skirts!) playing soldiers in a charity game around 1918”.

The next mention of women playing rugby comes many years later, in the " 1980 s" cabinet. Here, the exhibition text notes that the year 1980 saw the first women's 
representative game took place in Palmerston North. The exhibition notes that "it was a novel event rather than any intention of seriously establishing women's rugby as an organised sport". The text is accompanied by a few ephemera items inside the cabinet. Objects include a memento from a university team's tour later on in the decade, and a couple of team photos. The images are slightly obscured by other objects relating to the decade, including a police baton and helmet (pictured in figure 19) from the Springbok Tour protests. The ephemera inside the exhibition show that while the representative game did not signal a serious start to "women's rugby as an organised sport," women were actively playing the game all throughout the decade.

In the "1990s" cabinet, the exhibition again makes mention of women's rugby. This time, tracking the start of the Women's World Cup, beginning as an unofficial tournament in 1991, and then official in 1998. The exhibition text also notes that New Zealand Rugby finally began recognising the women's national team in 1993, and that the rugby union established the "official" provincial competition. This cabinet is supplemented by a few images of the women's rugby team, and a programme from a competition they played. The next and final mention of women players comes in the " 2000 s" cabinet. The exhibition marks the ongoing success of the women's rugby team, the Black Ferns, noting that they "have proved to be one of the most successful teams in modern international sport, despite being relegated to the edges of centre stage in favour of the men's team". On display in the cabinet is a Black Fern's jersey, a team photo, and an image of then captain, Dr Farah Palmer. Ironically, these objects are "relegated to the edges" of the cabinet, drowned out by images and objects relating to men's rugby. Right next to the women's collection on display, and taking up as much space, are a handful of images of scantily clad rugby player men modelling underwear. The "2000s" is the first real 
acknowledgement of the successes of women's rugby, along with some of the difficulties they faced by being "relegated to the edges". It is particularly interesting that the exhibition has chosen to further marginalise women's rugby through object placement.

On top of being mentioned as players, women are also mentioned within the exhibition in relation to their role in the background of rugby - as helpers, fans and so on. The first mention of a non-player woman is in the caption for a "cigarette case... belonging to 1905 All Black Jimmy Hunter" in the 1900s cabinet. The caption notes that "instead of money, the All Blacks received gifts from their supporters". In this case "a Māori woman in Sydney gave each player a cigarette case, inscribed with their name and signed 'from Ngawiri"”. As well as giving a small glimpse into women's participation in rugby off the field, this caption shows another issue that is prevalent throughout the exhibition. Just as the gender of a person in the exhibition is usually only mentioned if they are a woman, the same issue occurs with Māori. Note here, that Jimmy Hunter was not described as 'Pākehā man Jimmy Hunter'.

While not specifically about rugby, the 1900s and 1910s historical side panel notes, right after mentioning some women on the home front took the place of men on the rugby field, that "the dedication of Kiwi women as patient mothers, adept fundraisers and nurses and knitters of socks cemented the view that they too were plucky and skilled". Women again showed their "dedication" in the "1950s" cabinet where in the caption for a trunk full of "clean gear," it notes that "for women cleaning a team's strip it meant a copper tub boil, scrubbing, rinsing and wringing, and drying..." As well as being dedicated helpers, women are also briefly mentioned in the " 1950 s" cabinet for their role as "marching girls" in "pre-match street parades" during major tours. 
Although most explicitly gendered moments throughout the exhibition are about women, there are a few mentions of masculinity in the first few sections of the rugby museum. A section "The Manly Game," tracks the origins of "rugged" school boy games in colonial New Zealand. The exhibition cites an article from the Lyttelton Times which notes "we are glad to hear that a club is to be formed for the promotion of this manly game". Here the exhibition, shows that the game's origins were completely gendered. In the historical side panel next to the "1860s cabinet" under the title "Public school game," the exhibition discusses the origins of the game in Britain's elite public schools. The exhibition notes that “in the Victorian era, Rugby's emphasis on team sports, 'fair play' and an approach of allocating responsibility to boys, helped to shape the public school system's 'muscular christianity' ethos". Here, the exhibition links the game to views of the day around bodies, fitness, and the role of men in society. Masculinity is again mentioned in the "Early settlement" section, noting the "schoolboy shenanigans" in Nelson during the 1860s. The exhibition quotes a Nelson College Old Boy who wrote some years later of his time playing rugby in the 1860s: "no one was very particular about whether it was the ball or some schoolfellow's head, shins or any other part of the body, so long as he got a kick in". The following section discusses games between diggers during the gold rush, noting that they were a "rough and tumble sort," prone to playing "rowdy games" with "savage... onslaughts".

\section{'Real' New Zealand in the museum}

Both the Rugby Museum and The Topp Twins perpetuate discourses about New Zealand and New Zealand identity that boil down to what 'counts' as 'New Zealand'. Here, I would like to discuss the myth of 'real' New Zealand. That is, the idea that certain 
elements of New Zealand are more genuine than others. This is particularly prevalent in The Topp Twins, and the tropes around fairness, kiwiana and New Zealand geography. 'Real' New Zealand could be considered as an authorised heritage discourse. It is imbued with a sense of power that perpetuates particular discourses about New Zealand identity more specifically, who counts as a 'real' New Zealander. In The Topp Twins, two queer women have been put at the centre of 'real' New Zealand mythology. They are 'real' 'country girls'. This is powerful, particularly considering the literature on New Zealand identity that shows how marginalised women are in the national identity discourse. The placement of two queer women at the centre of 'real' is, as Anita Brady would put it "truly troubling". ${ }^{33}$ On the contrary, the Rugby Museum, much like rugby culture at large, relegates women to the margins of the exhibition. As the museum makes clear, rugby is a very important national story. Thus, where The Topp Twins, complicates the 'real' New Zealand discourse, the Rugby Museum further perpetuates its mythology and exclusionary practices. The problem here however, is that even when queer women are added to the picture, the discourse is still hegemonic, perpetuating a type of New Zealand that serves, for the most part, Pākehā New Zealand.

${ }^{33}$ Brady, 'Camp Mothers of a Nation?', 12-13. 


\section{Conclusion}

The final chapter of this thesis considered the ways gender and national identity are displayed within The Topp Twins exhibition and the New Zealand Rugby Museum. The reading of the two exhibitions showed that they both perpetuate tropes about New Zealand culture and identity. The Rugby Museum does this by perpetuating a genderless narrative centred on the achievements of men. The Topp Twins does this by placing queer women at the centre of hegemonic New Zealand culture. An important part of reading an exhibition as a text, according to Rhiannon Mason, is finding out the 'whole story'. Before examining the content and narratives within the exhibitions, this thesis sought to consider their wider context. Although it was not possible to attain visitor numbers or responses to this, contextual information has proven to be incredibly helpful endeavour. In Chapter Four, the thesis discussed the ways national identity and gender were put on display within the two exhibitions. With the information collected in Chapters Two and Three, it is now possible to conclude the thesis by considering why the issues raised in Chapter Four came about. While it is one thing to read, analyse and critique a museum exhibition, it is another thing entirely to consider those critiques within the wider context of the day to day realities of the museum.

During the early stages of planning, Te Manawa opted to bring in an 'outsider', Siân Torrington, to curate The Topp Twins. Primarily, Torrington was approached to curate the exhibition because of her experience as an artist. It was important for Lowe to have someone with a "creative eye", who could really honour the Twins' artistry. ${ }^{2}$ However, it

\footnotetext{
${ }^{1}$ Rhiannon Mason, 'Cultural Theory and Museum Studies,' in Companion to Museum Studies, ed. Sharon Macdonald (Malden, MA: Blackwell Publishers, 2006), 26-27.

${ }^{2}$ Andy Lowe, interview with the author, 2018.
} 
is also apparent that Torrington's queer perspective was also a necessary component for curating the show. As an artist, with some ties to the wider cultural sector, Torrington is not quite an 'outsider' to the museum, but as an independent artist who has no institutional ties, she is certainly not an 'insider' either.

In Sex Museums: The Politics and Performance of Display, Jennifer Tyburczy unpicks the ways museums shape sexual meaning. ${ }^{3}$ Although she argues that sexual meaning is produced in all museums regardless of intent, for the most part Tyburczy's analysis focuses on museums of sex and exhibitions that deal explicitly with sex. In her final chapter, Tyburczy outlines a framework for what she describes as "queer curatorship". In so doing, Tyburczy uses examples from the display of sadomasochism in museums. While the display of objects relating to sadomasochism may seem a far cry from The Topp Twins, Tyburczy’s “queer curatorship” model provides an interesting entry point into discussions of Siân Torrington's queer curation of the exhibition. Tyburczy outlines "queer curatorship" as being

an experimental display tactic that stages alternative spatial configurations for two distinct purposes: (1) to expose how traditional museums socialize heteronormative relationships between objects and visitors and (2) to cope with ethically fraught objects of queer cultures ${ }^{4}$

Tyburczy's concerns primarily reside in the spatial elements of museums, noting that "queer curatorship is simultaneously a mode for studying how museums place objects in

\footnotetext{
3 Jennifer Tyburczy, Sex Museums: The Politics and Performance of Display (Chicago and London: University of Chicago Press, 2016)

${ }^{4}$ Tyburczy, Sex Museums, 175.
} 
normative sexual relationships through the curatorial citation and repetition of familiar arrangements, juxtapositions, and chronologies" and "a method for experimenting with object arrangements toward the cultivation of other sexual-social relationships" ${ }^{\prime 5}$

Torrington notes that she was incredibly conscious of her responsibility as a queer curator telling a queer story. ${ }^{6}$ In explaining the effect this had on the overall exhibition, Torrington recalls two instances during the planning stages. When the exhibition team got to the "Being Out, Being Ourselves" section, covering the Twins' position as 'out' public figures, Torrington notes that there was a suggestion from someone to hang a glitter ball from the ceiling. While this suggestion was likely made in earnest, Torrington found herself having to explain to the exhibition team why "glittery" décor was not appropriate. Although a glitter ball may be appropriate for an exhibition about other people in the queer community, it was important to Torrington that the Twins' be displayed in a way that mirrored their reality as butch, rural women. Torrington notes that she felt as though there was an attempt to "tone down" the Twins" "butchness", citing another example where someone tried to "soften" an image of the Twins looking masculine wearing leather jackets by placing it over a gingham background. Ensuring that the Twins' "butchness" was visible was a crucial element of honouring the Twins' as individuals. This is particularly crucial, Torrington argues, in light of the fact that "we don't see butches very much". In Torrington's eyes, something as simple as "how we position images, what background we put them on matters. Everything matters". ${ }^{7}$

\footnotetext{
${ }^{5}$ Tyburczy, Sex Museums, 198.

${ }^{6}$ Siân Torrington, interview with the author, 2018.

${ }^{7}$ Ibid.
} 
Using Tyburczy's framework, Torrington's push back against attempts to "soften down" the Twins' queerness, both exposes the way museums can employ heteronormative display tactics and illustrates the ways queer curation can unsettle them. Considering queer curation in relation to Torrington's experience curating The Topp Twins, it becomes clear that themes of sexuality, and in turn, gender, are not simply present within the exhibition, but rather, have been grappled with, discussed, contested and displayed in very intentional ways. This mode of inquiry highlights the significance of having a queer person curating The Topp Twins, and perhaps alludes to how different the exhibition could have turned out had Torrington not been there. The Topp Twins in Torrington's view? “Only a queer person could have done that". 8 Torrington's experience as a queer curator is incredibly important here, and shows that ensuring queer representation was a central issue for her. By putting queer women at the centre of hegemonic discourses of New Zealand identity, Torrington was able to ensure that the Twins' queerness was normalised without shying away from the topic.

Kevin Moore argues that academic critique of sports museums are often unduly harsh, putting an unfair amount of emphasis on factual and historical accuracy. ${ }^{9}$ Academic critique has also tended to, according to Moore, neglect to see the value and need for 'nostalgia' in a sports museum. ${ }^{10}$ While this thesis has tried to be less pedantic about historical accuracy, and instead looked at the kinds of discourses the museum exhibits, even so, discussions have become quite academic, and in aid of a very specific goal. As

\footnotetext{
${ }^{8}$ Kevin Moore 'Sport in Museums and Museums of Sport: An Overview,' in Sport, History, and Heritage, ed. Jeffrey Hill, Kevin Moore and Jason Wood (Woodbridge, UK: Boydell Press, 2012), 93.

${ }^{9}$ Ibid.

${ }^{10} \mathrm{lbid}$.
} 
such, in researching the museum narrative, it is important that its wider context is considered here.

The Rugby Museum has one full time staff member and relies heavily on volunteer labour. Volunteers, naturally, are rugby fans. The museum has only recently got themselves out of debt from the 2011 renewal, and are now faced with uncertainty about the future with Te Manawa 2025 redevelopments on the horizon. While director Stephen Berg notes that the museum is "totally on board" with the proposal for a redevelopment, the museum is left wondering how they are meant to update the exhibition. While Chapter Four shows that the Rugby Museum could do more to improve the way they talk about New Zealand and gender, wider research shows how difficult doing such a thing would be for the museum. Perhaps with the 2025 redevelopments on the horizon, the museum will be able to take this opportunity to expand the rugby story to include a large portion of 'New Zealand'?

For a short period of time in 2017 , two museum exhibitions converged. One filled with the shenanigans of two activist lesbian women, and the other filled with mementoes of the country's most popular sporting pastime. The paradoxical convergence of two exhibitions seemingly so different in subject matter, ended up united in their 'love for New Zealand'. This thesis has raised questions about how and why this happened. It does not, however, grapple with the most difficult issue: where to from here? This thesis raises the question of how do we display the New Zealand story in an inclusive manner? But it also raises the question: is it possible to display a New Zealand story, or are there many? 


\section{Bibliography}

Aitchison, Cara. 'Heritage and Nationalism: Gender and the Performance of Power,' in Leisure/Tourism Geographies: Practices and Geographical Knowledge (Abingdon, UK: Taylor and Francis, 2000), 59-73

Anderson, Bettina. Interview with author. 2018

Bannister, Matthew. “"Bush Camp”? The Topp Twins and Antipodean Camp,' Australasian Journal of Popular Culture 4, no. 1 (2015): 3-14

Bartlett, Alison and Margaret Henderson. 'Feminism and the Museum in Australia: An Introduction,' Journal of Australian Studies 40, no. 2 (2016): 132-33

Berg, Stephe. Interview with author, 2018

Brady, Anita. 'Camp Mothers of the Nation? Reading Untouchable Girls,' Women's Studies Journal 24, no. 1 (2010): 3-13

Brady, Anita. 'The Transgendered Kiwi: Homosocial Desire and 'New Zealand Identity,' Sexualities 15, no. 3/4 (2012): 355-372

Butler, Judith. 'Preface (1999),' Gender Trouble: Feminism and the Subversion of Identity, 2nd edition (London \& New York: Routledge, 1999)

Butler, Judith. Bodies That Matter, (London \& New York: Routledge, 1993)

Butler, Judith. Undoing Gender, (London \& New York: Routledge, 2004)

Conlan, Anna. 'Representing Possibility: Mourning, Memorial, and Queer Museology,' in Gender, Sexuality and Museums, ed. Amy K. Levin (London \& New York: Routledge, 2010), 253-63 
Daley, Caroline. 'The Invention of 1905 ' in Tackling Rugby Myths: Rugby and New Zealand Society, 1854-2004, ed. Greg Ryan (Dunedin: Otago University Press, 2005), 6987

Daley, Caroline. 'The Ref's Turned a Blind Ear': The Cultural Paradigm and New Zealand's Sport History,' Sporting Traditions 27, 8 (2010), 15-27

Denscombe, Martyn. The Good Research Guide, 3rd edition (Berkshire, UK: Open University Press, 2007)

Edensor, Tim and Uma Kothari. 'The Masculinisation of Stirling's Heritage,' in Tourism: A Gender Analysis (Chichester, UK: Wiley, 1994), 164-87

Evans, Jessica. 'Introduction: Nation and Representation,' in Representing the Nation: A Reader. Histories, Heritage and Museums, ed. David Boswell and Jessica Evans (London and New York: Routledge and The Open University, 1999), 1-7

Fairburn, Miles. 'Is there a Good Case for New Zealand Exceptionalism?', Thesis Eleven 92 (2008): 45

Gibbons, Peter. 'Cultural Colonization and National Identity', New Zealand Journal of History 36, no. 1 (2002): 5-17

Gibbons, Peter. 'The Far Side of the Search for New Zealand National Identity', New Zealand Journal of History 37, 1 (2003): 39

Halberstam, Jack. Female Masculinity (Durham: Duke University Press, 1998)

Hall, Stuart. 'Whose Heritage? Un-Settling "the Heritage”, Re-Imagining the PostNation,' in The Politics of Heritage: The Legacies of Race, ed. Jo Littler and Roshi Naidoo (London \& New York: Routledge, 2005), 21-31

Johnston, Lynda. 'The Topp Twins: Untouchable Girls: The Movie,' Emotion, Space and Society 2 (2009): 70-72 
Knell, Simon. 'National Museums and the National Imagination,' in National Museums: New Studies from Around the World, ed. Simon Knell, Peter Aronsson, and Arne Bugge Amundsen (London and New York: Routledge, 2010)

Law, Robin, Hugh Campbell and John Dolan, ed., Masculinities in Aotearoa/ New Zealand (Palmerston North: Dunmore Press, 1999)

Levin, Amy K. 'Introduction,' in Gender, Sexuality and Museums: A Routledge Reader (London \& New York: Routledge, 2010)

Lowe, Andy. Interview with author. 2018

Machin, Rebecca. 'Gender Representation in the Natural History Galleries at the Manchester Museum,' in Gender, Sexuality and Museums: A Routledge Reader, ed. Amy K. Levin (London \& New York: Routledge, 2010)

Mason, Rhiannon. 'Cultural Theory and Museum Studies,' in Companion to Museum Studies, ed. Sharon Macdonald (Malden, MA: Blackwell Publishers, 2006)

McKergow, Fiona and Kerry Taylor, eds. Te Hao Nui - The Great Catch: Object Stories from Te Manawa (Auckland: Godwit, 2011)

Moore, Kevin. 'Sport in Museums and Museums of Sport: An Overview,' in Sport, History, and Heritage, ed. Jeffrey Hill, Kevin Moore and Jason Wood (Woodbridge, UK: Boydell Press, 2012)

Perry, Nicholas. Hyperreality and Global Culture (London \& New York: Routledge, 1998)

Peter Vergo, ed., The New Museology (London: Reaktion Books, 1989)

Phillips, Jock. A Man's Country? The Image of the Pakeha Male. A History, 2nd ed. (Auckland: Penguin, 1997) 
Phillips, Jock. A Man's Country? The Image of the Pakeha Male: A History, 2nd edition (Auckland: Penguin, 1997)

Phillips, Murray G. 'Introduction: Historians in Sports Museums,' in Representing the Sporting Past in Museums and Halls of Fame, ed. Murray G. Phillips (London \& New York: Routledge, 2012), 1-28

Porter, Gaby. 'Seeing through Solidity: A Feminist Perspective on Museums,' in Theorizing Museums, ed. Sharon Macdonald and Gordon Fyfe (Woodbridge, UK: Blackwell Publishers, 1996), 105-26

Porter, Gaby. 'Studies in Gender and Representation in British History Museums' (PhD, University of Leicester, 1994)

Reading, Anna. 'Making Feminist Heritage Work: Gender and Heritage,' in The Palgrave Handbook of Contemporary Heritage Research, ed. Emma Waterton and Steve Watson (Hampshire \& New York: Palgrave Macmillan, 2015)

Sinclair, Keith. A Destiny Apart: The Search for New Zealand National Identity (Wellington: Allen and Unwin, 1986)

Smith, Laurajane. 'A Pilgrimage of Masculinity: The Stockman's Hall of Fame and Outback Heritage Centre,' Australian Historical Studies 43, no. 3 (2012): 472-82

Smith, Laurajane. 'Heritage, Gender and Identity,' in The Ashgate Research Companion to Heritage and Identity, ed. Brian Graham and Peter Howard (Hampshire: Ashgate, 2008)

Smith, Laurajane. 'The "Doing” of Heritage: Heritage as Performance,' in Performing Heritage: Research, Practice and Innovation in Museum Theatre and Live Interpretation, ed. Jackson Anthony and Jenny Kidd (Manchester: Manchester University Press, 2012), 69-81 
Smith, Laurajane. Uses of Heritage (London \& New York: Routledge, 2006)

Torrington, Siân. Interview with author. 2018

Tyburczy, Jennifer. Sex Museums: The Politics and Performance of Display (Chicago \& London: University of Chicago Press, 2016)

Vamplew, Wray. 'Taking a Gamble or a Racing Certainty: Sports Museums and Public Sports History,' Journal of Sport History 31, 2 (2004

Wallace, Lee. 'Queer, Here: Sexuality and Space,' in Cultural Studies in Aotearoa/ New Zealand (Melbourne: Oxford University Press, 2004)

Wu, Zongjie and Song Hou. 'Heritage and Discourse,' in The Palgrave Handbook of Contemporary Heritage Research, ed. Emma Waterton and Steve Watson (Hampshire \& New York: Palgrave Macmillan, 2015), 37-51

Jools Topp, interviewed by Giles Dexter, Newshub, Three, 26 March 2018.

https://www.newshub.co.nz/home/entertainment/2018/03/topp-twins-colourful-historygoes-on-display.html/

The Topp Twins: Untouchable Girls, directed by Leanne Pooley. Rialto, 2009

'The Topp Twins,' Anika Moa Unleashed, TVNZ, 20 June 2018

'Rugby Jamboree,' Eventfinda, archived in August 2018 via Internet Archive, https://web.archive.org/web/20180821114926/https://www.eventfinda.co.nz/2018/rugbyjamboree/palmerston-north

'The Great Exhibition,' Victoria and Albert Museum, archived in February 2018 via Internet Archive, https://web.archive.org/web/20180207221907/http://www.vam.ac.uk/page/g/great$\underline{\text { exhibition/ }}$ 
Peter Lampp, 'Rugby Museum Founder a Visionary,' Manawatū Standard, 21 March 2013, http://www.stuff.co.nz/manawatu-standard/sport/8454661/Rugby-Museumfounder-a-visionary

Minister of Internal Affairs, Chris Tremain and Minister for Arts, Culture and Heritage, Chris Finlayson, Diverse funding for World War One Centenary, 2013, https://www.beehive.govt.nz/release/diverse-funding-world-war-one-centenary

Diana Anderson-Minshall, 'Michfest's Founder Chose to Shut Down Rather Than Change with the Times,' Advocate, 24 April 2015, https:/www.advocate.com/commentary/2015/04/24/op-ed-michfests-founder-chose-shutdown-rather-change-times.

'Querying Kiwi Comedy,' Eventfinda, archived in February 2018 via Internet Archive, https://web.archive.org/web/20180228022444/https://www.eventfinda.co.nz/2017/topptwins $2 /$ palmerston-north

'True Blue Boys: The Topp Twins and New Zealand identity,' Eventfinda, archived in February 2018 via Internet Archive, https://web.archive.org/web/20180228022855/https://www.eventfinda.co.nz/2017/trueblue-boys-the-topp-twins-and-new-zealand-identity2/palmerston-north

'Twin Psychology from Birth to Adulthood,' Eventfinda, archived in February 2018 via Internet Archive, https://web.archive.org/web/20180228022612/https://www.eventfinda.co.nz/2017/publictalk-twin-psychology-from-birth-to-adulthood/palmerston-north

'Public Talk: Rural Women of New Zealand,' Eventfinda, archived in February 2018 via Internet Archive,

https://web.archive.org/web/20180228022825/https://www.eventfinda.co.nz/2017/publictalk-rural-women-of-new-zealand/palmerston-north

'Smashing the Ceiling: Finding Equality in the Local Music Scene,' Eventfinda, archived in February 2018 via Internet Archive, 
https://web.archive.org/web/20180228022754/https://www.eventfinda.co.nz/2017/songwr iters-circle/palmerston-north.

Janine Rankin, 'Te Manawa aims for a \$58m rebuild,' Manawatū Standard, 14 August 2017, https://www.stuff.co.nz/manawatu-standard/news/95703371/te-manawa-aims-fora-58m-rebuild

Janine Rankin, 'Huge task ahead to design a new Te Manawa,' Manawatū Standard, 16 August 2017, https://www.stuff.co.nz/manawatu-standard/news/95703371/te-manawaaims-for-a-58m-rebuild

Andy Lowe quoted in 'Open studio brings museum to life,' IHC Foundation, 7 March 2017, archived May 2018 via Internet Archive, https://web.archive.org/web/20180523014526/https://www.ihcfoundation.org.nz/who-wefund/2017/3/7/open-studio-brings-museum-to-life

Janine Rankin, 'Te Manawa rebuild planning gets $\$ 40,000$ boost,' Manawatū Standard, 28 August 2017, https://www.stuff.co.nz/manawatu-standard/news/96217909/te-manawarebuild-planning-gets-40000-boost

'Te Manawa 2025 redevelopment,' The Big Picture: Palmerston North City Council, April 2018, archived August 2018 via Internet Archive, https://web.archive.org/web/20180827082422/https://thebigpicture.pncc.govt.nz/majorprojects/city-centre-transformation/te-manawa-2025-redevelopment

Jono Galuszka, 'Te Manawa upgrade project gets funds for next steps,' Manawatū Standard, 1 June 2018, https://www.stuff.co.nz/manawatu-standard/news/104306187/temanawa-upgrade-project-gets-funds-for-next-steps

Andy Lowe quoted in Janine Rankin, 'Art Gallery closes temporarily for repairs,' Manawatū Standard, 1 July 2018, https://www.stuff.co.nz/manawatustandard/news/105138761/art-gallery-closes-temporarily-for-repairs 
'Art Gallery Renewal Project,' Te Manawa, 20 August 2018, archived August 2018 via Internet Archive

https://web.archive.org/web/20180827093729/https://www.temanawa.co.nz/artgallery/.

'About,' Te Manawa, archived in February 2018 via Internet Archive, https://web.archive.org/web/20180220035700/https://www.temanawa.co.nz/about/

'Societies,' Te Manawa, archived in February 2018 via Internet Archive, https://web.archive.org/web/20180220040235/https://www.temanawa.co.nz/about/societi $\underline{\mathrm{es} /}$

'Te Rangi Whenua,' Te Manawa, archived in February 2018 via Internet Archive, https://web.archive.org/web/20180220035736/https://www.temanawa.co.nz/event/364191 I

'Manawatū Journeys,' Te Manawa, archived in February 2018 via Internet Archive, https://web.archive.org/web/20180220035745/https://www.temanawa.co.nz/event/364425 $\underline{1}$

'Te Awa - The River - Heart of Manawatū,' Te Manawa, archived in February 2018 via Internet Archive, https://web.archive.org/web/20180220035810/https://www.temanawa.co.nz/event/384680 1

Lara Lindsay-Parker, 'An Interview with Siân Torrington,' Enjoy, 26 August 2016, archived in May 2018 via Internet Archive, https://web.archive.org/web/20180523013631/http://enjoy.org.nz/blog/2016/08/aninterview-with-sian-torrington

Valerie Love, 'Describing Jools and Lynda,' National Library, September 2014, https://natlib.govt.nz/blog/posts/describing-jools-and-lynda 
'The Topp Twins: An Exhibition for New Zealand,' Te Manawa, archived in August 2017 via Internet Archive,

https://web.archive.org/web/20170810084035/https://www.temanawa.co.nz/topptwins/.

'On exhibition,' Waikato Times, 6 December 2012, 14; 'On exhibition,' Waikato Times, 7 February 2013, 12

'The Topp Twins: An Exhibition for New Zealand,' Te Manawa, archived in February 2018 via Internet Archive,

https://web.archive.org/web/20180225030144/https://www.temanawa.co.nz/topptwins/.

Grant Chapman, 'NZ Rugby’s “Diversity is Strength” campaign perfect answer to Folau fallout,' Newshub, 23 April 2018. https://www.newshub.co.nz/home/sport/2018/04/nzrugby-s-diversity-is-strength-campaign-perfect-answer-to-folau-fallout.html.

'The Topp Twins: An Exhibition for New Zealand,' Te Manawa, archived in August 2017 via Internet Archive,

https://web.archive.org/web/20170810084035/https://www.temanawa.co.nz/topptwins/.

'About Us,' New Zealand Rugby Museum, archived in January 2018 via Internet Archive, https://web.archive.org/web/20180121011738/http://rugbymuseum.co.nz/about$\underline{\mathrm{uS} /}$

Te Manawa Museums Trust, Annual Report, 2014/15

Te Manawa Museums Trust, Annual Report, 2015/16

Te Manawa Museums Trust, Annual Report, 2016/17

Te Manawa Museums Trust, Statement of Intent, 2016/16-2018/19

Te Manawa Museums Trust, TM2025, April 2018 